Texto extraido da tese de livre-docência Paisagem, Urbanização e Litoral Do éden à cidade

Objetiva introduzir uma reflexão sobre os padrões de loteamento existentes em áreas turisticas, tendo-se como ênfase as áreas costeiras e os resultados paisagísticos resultantes.

This paper focuses the relationship between the traditional urban pattern of green neighbourhoods and the ocupation of the coastal zone by residential touristics areas and this efects over the primitive landscape. 


\title{
Paisagem, Modelos Urbanisticos e as Áreas Habitacionais de Primeira e Segunda Residência
}

\begin{abstract}
A
partir do final do século 19, novas posições do urbanismo se consolidam na Europa e Estados Unidos, em oposição à clássica cidade industrial existente. Estas novas posturas privilegiam a construção do edifício isolado (casa ou prédio) em meio ao chamado "verde" como padrão do assentamento urbano moderno'

Este é o paradigma também adotado pela sociedade brasileira, que tem na época como primeiros exemplos configurados os bairros destinados às elites de grandes cidades como Rio de Janeiro (Laranjeiras) e São Paulo (Higienópolis) ${ }^{2}$ Nesta última, configuram-se prédios isolados cujos recuos são exigidos muitas vezes por meio de normas específicas feitas pelos próprios loteadores, que as adotam como meio de valorizar seus empreendimentos e posteriormente conseguem do poder público sua implementação.
\end{abstract}

(1) Observando-se posturas de diferentes autores do período, detecta-se em praticamente todas posições que direcionam, de um modo ou de outro, a consolidação deste padrão. Sobre algumas delas discorre Choay em seu livro $O$ urbanismo:

"Qualquer habitação ou outra construção pode compreender um ou vários lotes, mas a superfície construída deverá ser sempre inferior à metade da superfície total, sendo que o restante do lote forma um jardim público. - sobre a Cidade Industrial de Tony Garnier, França.

"Um cinturão de casas muito bem construídas e levantadas em um terreno próprio e espaçoso" - idéias para a cidade-jardim de Ebenezer Howard, Inglaterra.

"Mas sim apartamentos que abram todas as suas faces para o ar e a luz e que não teriam mais visāo para árvores doentias dos bulevares atuais, mas sim para relvas, para áreas reservadas a jogos e a plantações.

- posiçōes de Le Corbusier, França.

In: CHOAY, F O urbanismo.p. 165, 122 e 191.

(2) "Por volta dos últimos anos do século XIX e no início do século XX, antes de 1914, podia-se considerar como completa a primeira etapa da libertaçāo da arquitetura em relaçāo aos limites dos lotes.

"Naquela época, nos bairros da zona sul do Rio de Janeiro, em Higienópolis e Campos Elíseos em São Paulo, os arquitetos mais ousados orientavam a construção de casas como soluçōes arquitetônicas mais 'atualizadas', com jardins amplos, porões altos e programas mais complexos."

In: REIS FILHO, Nestor Goulart. Quadro da arquitetura no Brasil, p. 56.

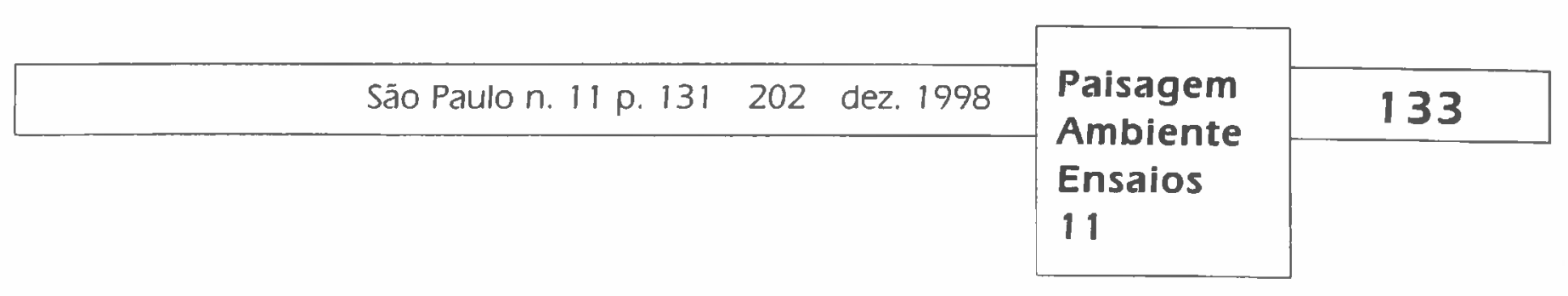


No início do século 20 surgem em São Paulo - formados pela Cia. City - os bairros formalmente inspirados na cidade-jardim ${ }^{3}$ e que se tornam padrões de urbanização para as áreas residenciais das camadas de maior poder aquisitivo do país. Trata-se da casa edificada no meio do lote, totalmente recuada e cercada de jardins ${ }^{4}$

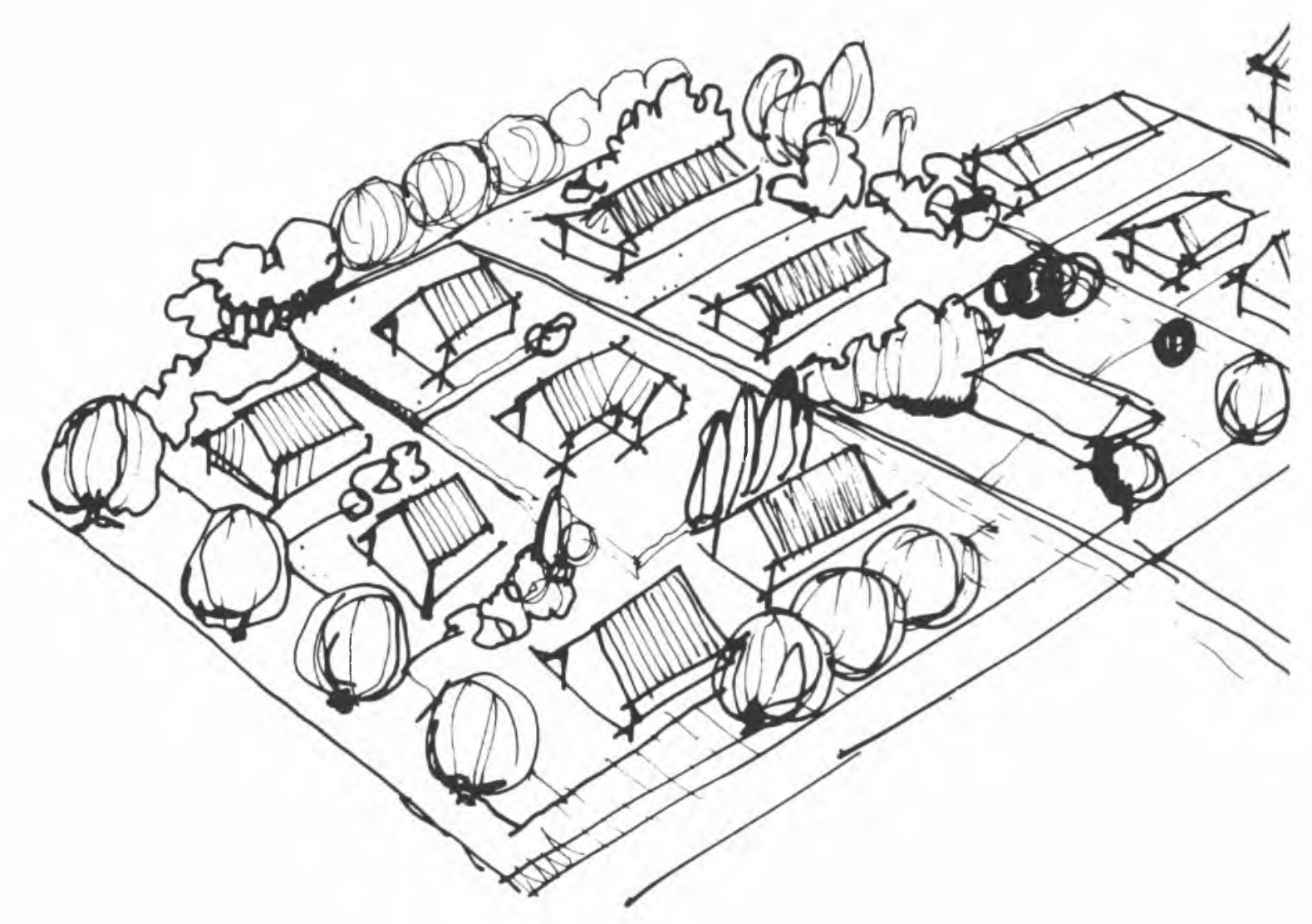

(3) "O termo cidade-jardim deve ser entendido com as limitaçōes que já foram vistas; não cidade, mas bairro satélite de uma cidade, dotado de um relacionamento favorável entre edifícios e áreas verdes, e sujeitos a certos vínculos de modo que o ambiente seja respeitado.

In: BENEVOLO, L. História da arquitetura moderna, p. 360.

(4) Estes padrões são adotados posteriormente para quase toda a cidade, como se pode observar no seguinte texto:

"Os recuos mínimos, um padrāo em Higienópolis consolidado por normas e por tradiçāo, são adotados oficialmente para toda a cidade em 1934, transportando para o todo urbano, à exceção da área central. o modelo 'moderno' de implantação no lote.

In: MACEDO, Silvio Soares. Higienópolis, p. 51.

"Na prática estes loteamentos - postos em voga em São Paulo pela Cia. City - ao transporem os esquemas ingleses da cidade-jardim sofriam adaptações várias, reduzindo-se, na maioria das vezes, a um aperfeiçoamento do sistema viário e a uma reinterpretação, em termos de paisagismo, dos velhos lotes tradicionais. Deste modo subsistiam os jardins e recuos obrigatórios, mas desapareciam as áreas de uso comum, de grande importância nos planos dos estrangeiros.

In: REIS FILHO, Nestor Goulart. Ouadro da arquitetura no Brasil, p. 71 


\section{PADRÃO COLONIAL}

DE InPLSNTACAO DO EDIFKCIO

\section{NO LOTE}
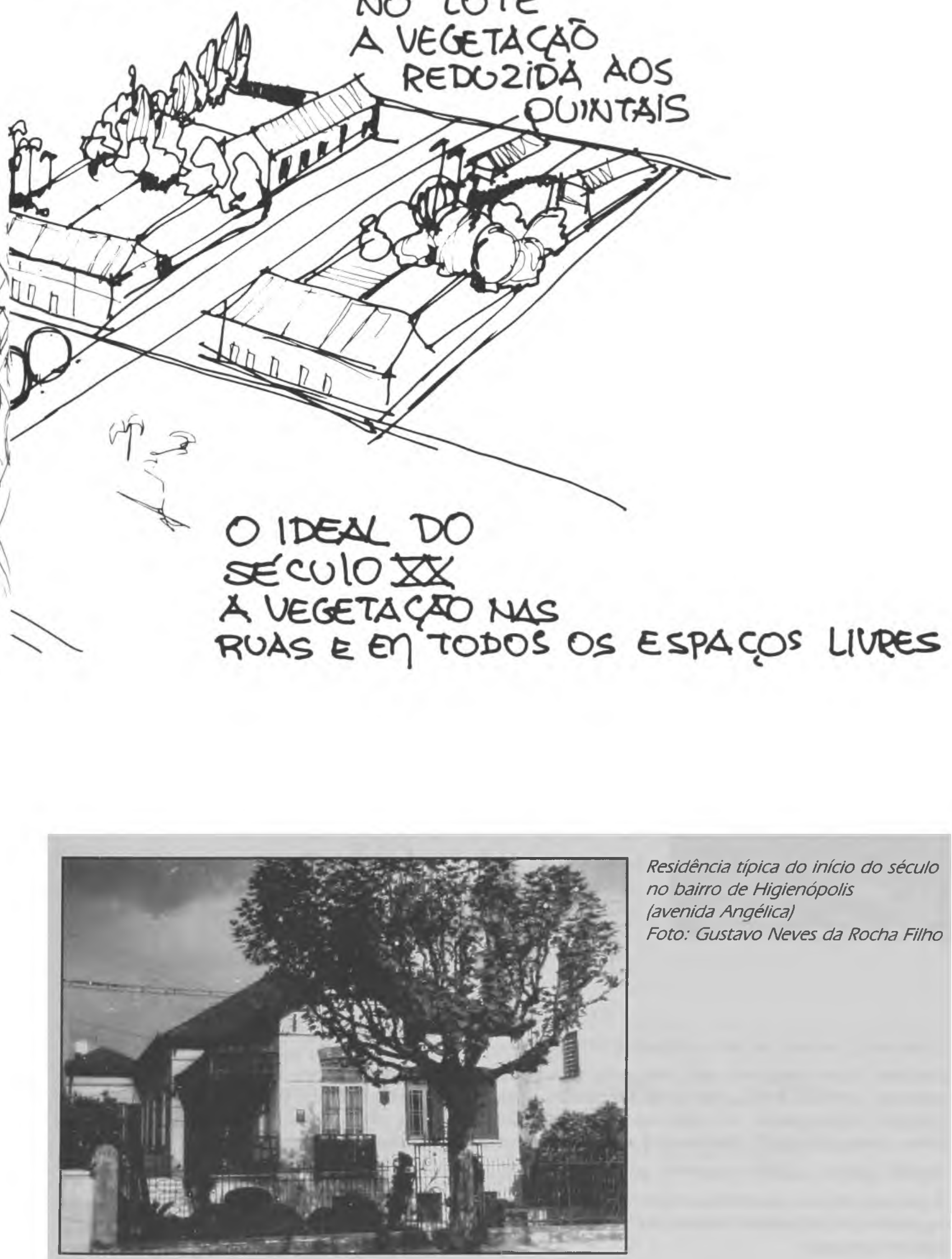

Residência típica do início do século no bairro de Higienópolis (avenida Angélica)

Foto: Gustavo Neves da Rocha Filho

O IDEAL DO

A VEGETACAO NAS

RUAS E EY TODOS OS ESPACQOS LIURES 
Sílvio Paisagem, Modelos Urbanísticos e

Soares as Áreas Habitacionais de Primeira

Macedo e Segunda Residência

Este padrão substitui o velho modelo de edificações geminadas 5 . alinhadas ao longo das ruas, e estrutura ainda hoje importantes áreas das cidades brasileiras, visto que é tido como o "protótipo ideal de habitação para todos"b.
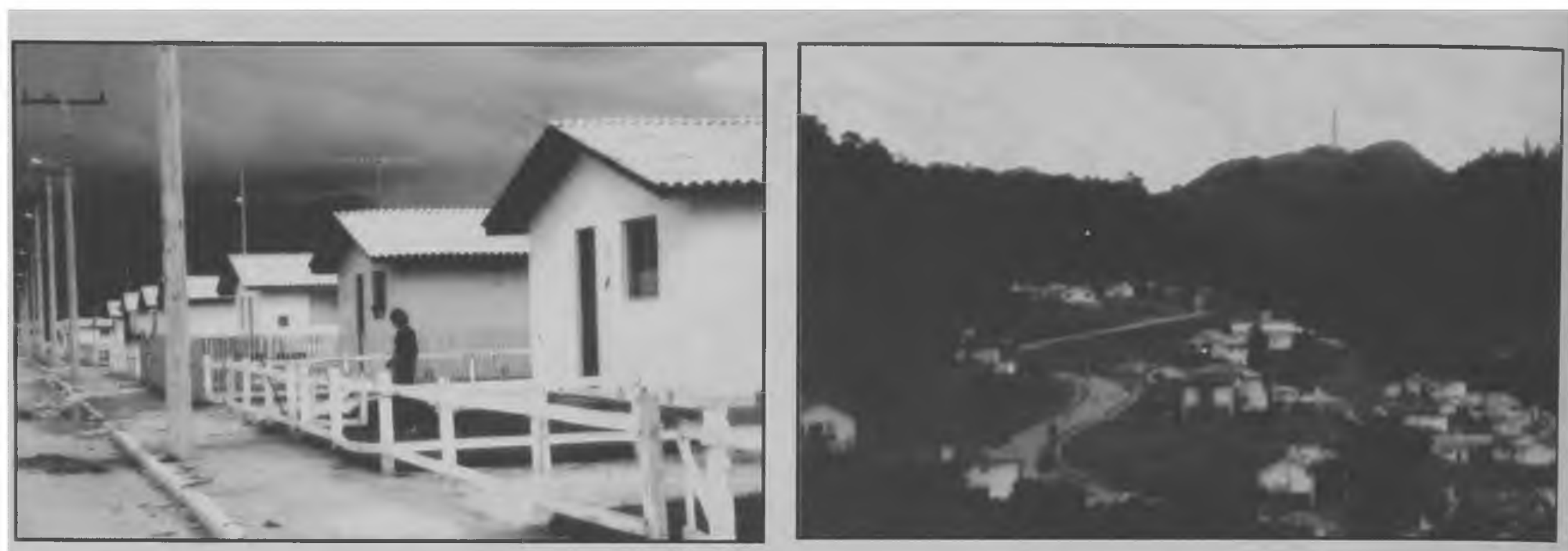

Tanto nos bairros populares como nos bairros mais ricos, a residência isolada é o padrão desejado. Os exemplos mostram esta forma de assentamento em duas situaçōes diversas: em um loteamento BNH - (Forquilhinha) e em um condomínio em Trindade, ambos em Florianópolis (SC), 1981

Fotos: Silvio Soares Macedo

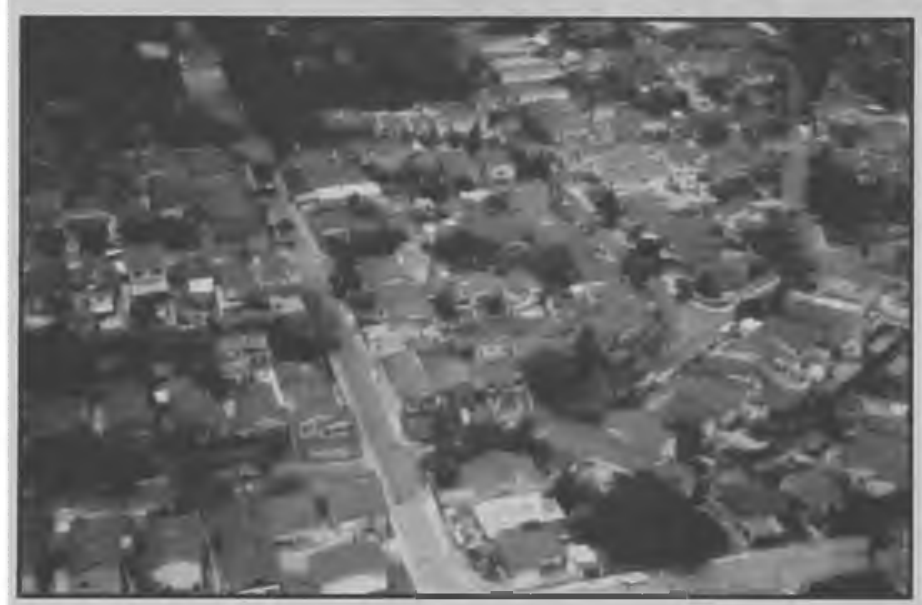

Bairro de classe média em São Paulo, de casas com recuos e ruas e lotes arborizados, guardando em muito a semelhança com os bairros-jardins da cidade

Fotos: Silvio Soares Macedo

(5) Sobre este período se tem a seguinte síntese:

"Os solares ficam cada vez mais recuados nos grandes lotes, primeiro dos lados e depois na frente, ostentando jardins. Hoje, este jeito de morar, mais vulgarizado embora restrito, é ilustrado pelas residências esparramadas em meio ao verde nos bairros-jardins. Estes por sua vez ilustram como nas cidades contemporâneas cresceram e se afirmaram setores exclusivamente residenciais.

In: MARX, Murilo. Cidade brasileira, p. 99.

(6) A simples leitura das revistas especializadas em arquitetura e decoração ou dos periódicos dedicados a engenheiros e arquitetos mostra a cristalização deste padrāo, que é construido igualmente por todas as cidades do país. 


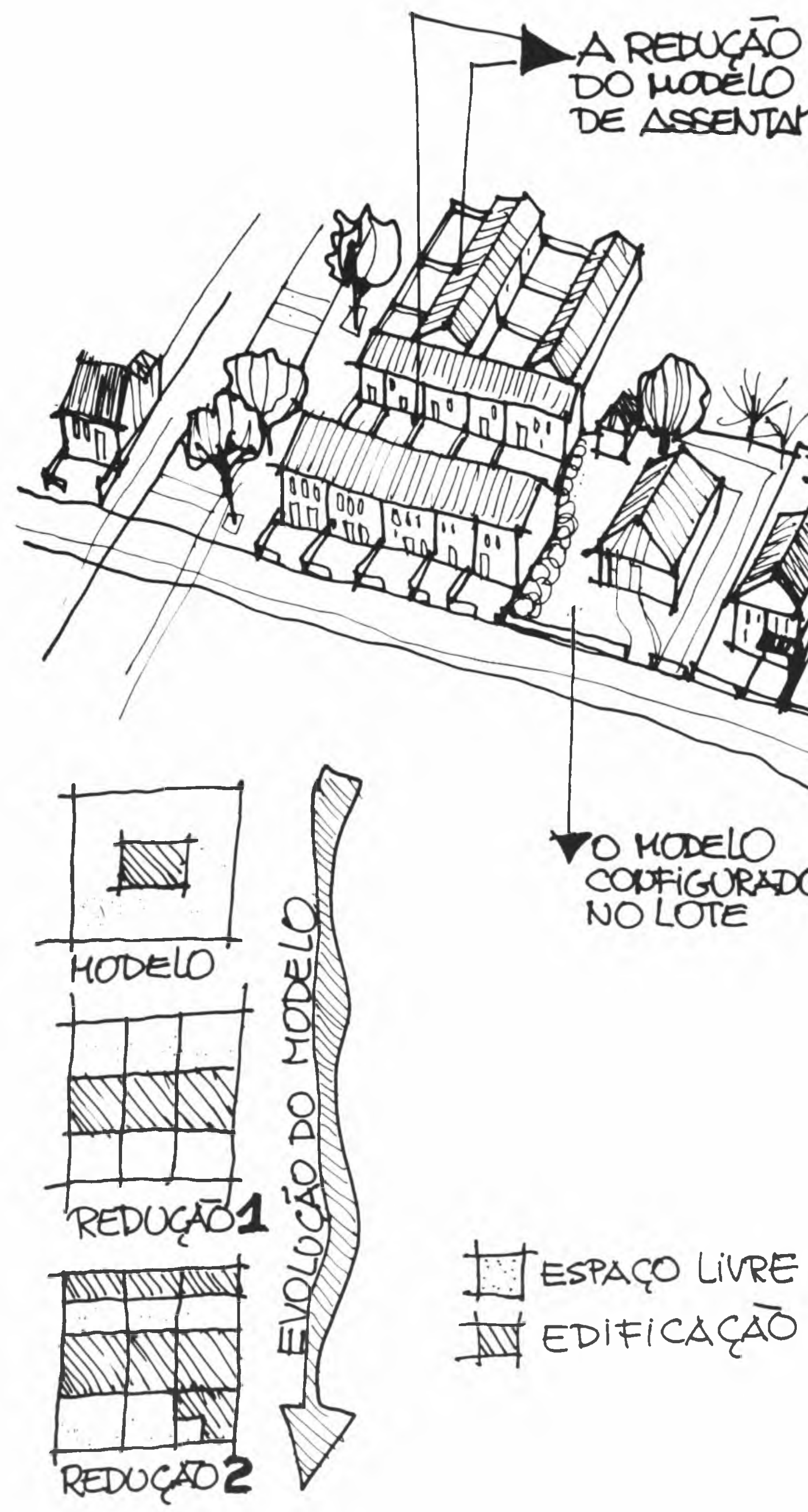


Mas existem fatores como a disponibilidade de terras e recursos e a exigüidade de lotes que condicionam ao padrão modificações sensíveis, de modo a adaptá-lo às realidades urbanas existentes. $O$ que se observa é a tolerância a edifícios total ou parcialmente geminados e a supressão de recuos frontais, criando-se então formas alternativas já consolidadas de assentamento.

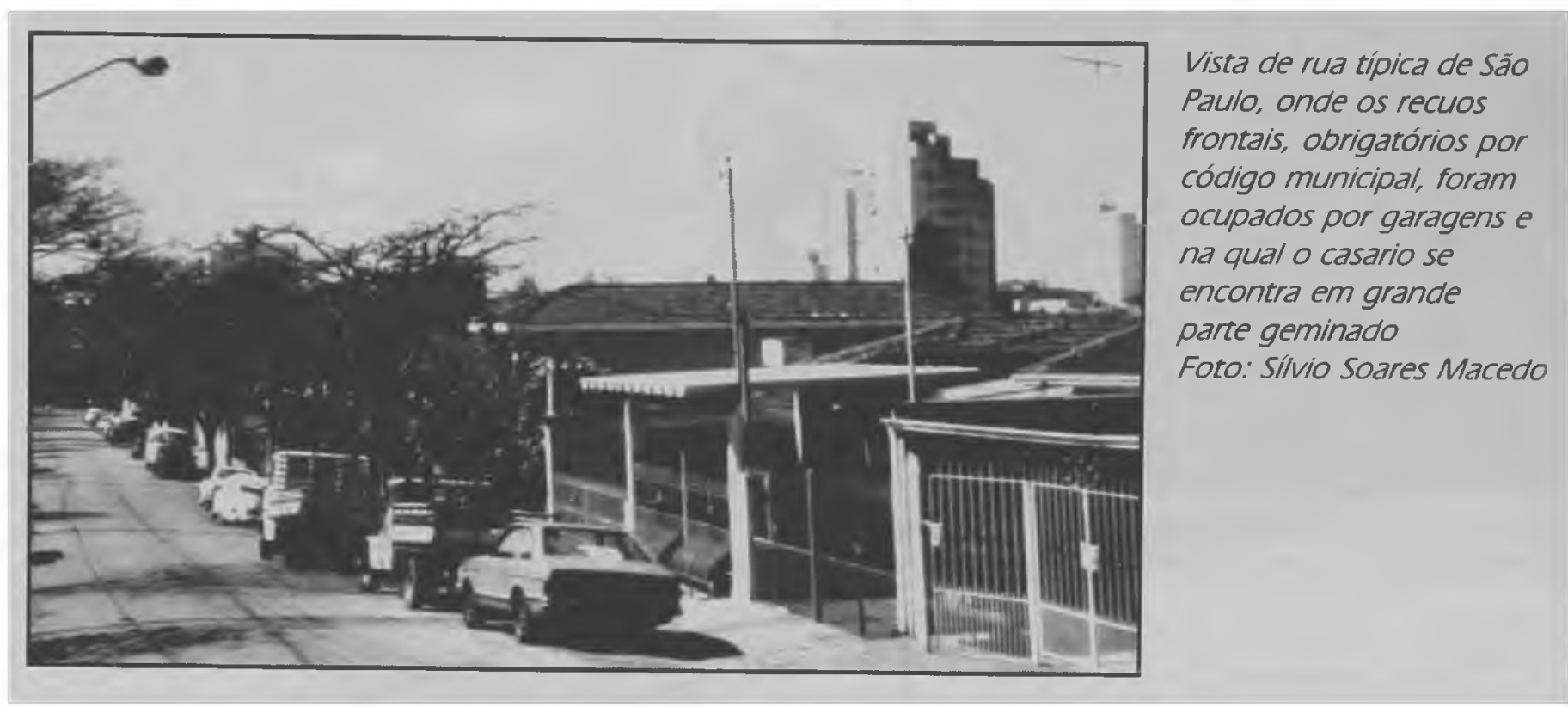

Paralelamente, o modelo da casa isolada e do bairro verde persistem no ideário das camadas mais abastadas e de setores significativos das classes médias urbanas que, à medida que possuem condições de manter uma segunda residência (uma casa de campo ou de praia) optam pela construção de um edifício seguindo tais padrões.

Desta forma, nas cidades de veraneio e nos subúrbios afastados das grandes metrópoles e ao longo da costa, implantam-se loteamentos que visam unicamente reproduzir tal modelo. São condomínios fechados, loteamentos convencionais em xadrez à beira-mar, junto a represas ou em áreas de montanha, que contêm na essência a idéia de possibilitar a compra de um espaço no qual o usuário possa construir a sua casa segundo padrões urbanísticos que raramente são obtidos em sua primeira residência 7

(7) "Como no passado, os padrões e desejos se repetem. A busca dos subúrbios no século XIX estava alicerçada, como hoje está a busca destas áreas de veraneio, em ambições e expectativas similares. "

"Para as famílias da burguesia, os subúrbios ofereciam um ambiente sequro e higiênico, casas novas de um estilo que de modo algum se adaptavam à sua concepçāo de vida familiar, e vizinhos mesmo que fossem temporários que pensavam do mesmo modo.

GLAAB E BROWN EM SICA, Paolo. História del urbanismo EI Siglo XIX. 2, p. 1049 

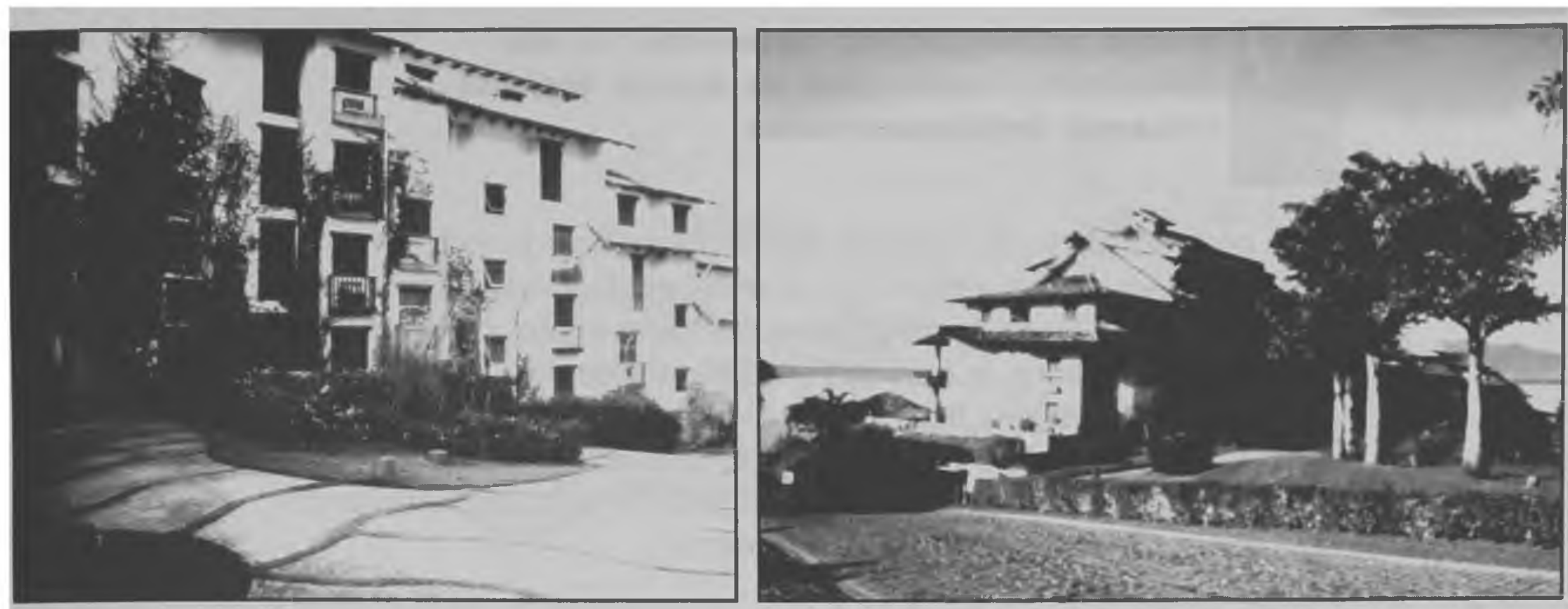

Condomínio Gaivotas, Caraguatatuba - típico empreendimento de alto padrāo do litoral paulista Fotos: Sívio Soares Macedo

Nestes locais são valorizadas as figuras do jardim e do quintal, da arborização em amplos gramados da vizinhança. A habitação é sempre destinada ao apoio de uma temporada de lazer (fim de semana ou férias).

Entretanto, estes loteamentos têm um uso restrito devido ao fato de serem a segunda ou até a terceira residência de uma família (situação esta que reduz drasticamente a exigência de senviços e infra-estrutura).

Geralmente tais situações urbanas não fazem parte de um todo urbano coeso e podem ser consideradas fragmentos de uma situação alheia à municipalidade em que se situam. Os benefícios diretos à população do município, como empregos e impostos, são limitados por este caráter específico de "segunda residência"8.

Esta forma de ocupação urbana visa basicamente a apropriação de um valor paisagístico significativo intrínseco à região sobre o qual se implanta, e que constituem cenários para a implementação de tais loteamentos, criando o que se pode chamar de "subúrbio de férias"

(8) "freqüentemente as autoridades municipais nāo exercem um efetivo controle do uso da terra, permitindo ao capital privado urbanizar, com fins comerciais e até especulativos, áreas que no futuro nāo poderão ser servidas pelos serviços públicos (1960)"

Citação da Carta dos Andes, em BIRKHOLZ, L. Evolução do conceito de planejamento territorial. In: BIRKHOLZ et al. Ouestōes de organização do espaço regional, p. 19. 
Sílvlo

Soares

Macedo

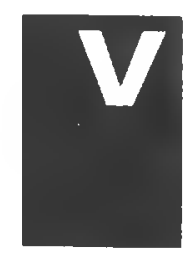

\section{alores paisagisticos existentes e sua compatibilizaçăo com os novos tecidos urbanos implementados}

Toda nova ocupação de veraneio modifica a morfologia existente para adequá-la ao ideário urbano do bairro-jardim, onde o terreno é modelado e parcelado de modo a receber casas e lotes convencionais de dimensões maiores que os existentes dentro de uma malha urbana tradicional. O produto final geralmente exalta a formalização do cenário ideal de habitação urbana, onde o edifício residencial está, de modo generoso, implantado em meio a jardins e pomares, guardando uma distância conveniente de seus vizinhos?

Na maior parte dos casos não existe o cuidado ou a consciência da adequação e do aproveitamento total ou parcial, dos valores paisagísticos e ambientais existentes. Quanto mais populares forem os loteamentos, menores serão as chances de conservação de parcelas significativas de tais valores, pois os lotes pequenos exigem arruamentos mais densos para sua implementação e mais área do lote para a construção do edifício. Assim, o espaço para a coexistência da vegetação nativa e os pequenos cursos d'água com os novos loteamentos será menor.

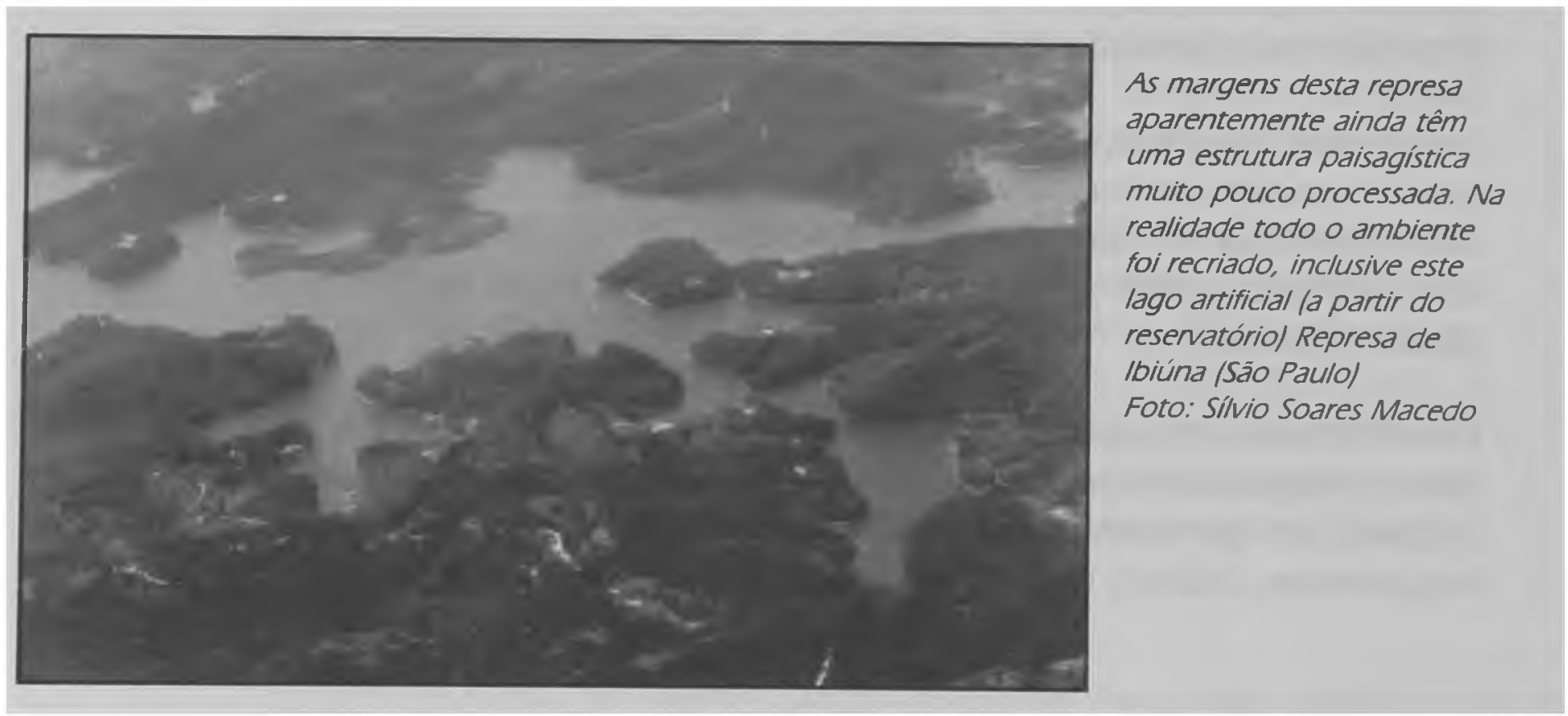

(9) "Quando se ocupa uma nova área, os novos ocupantes trazem com eles imagens de paisagens das fontes mais diversas; das suas vizinhanças, dos seus lugares de origem, história, fotografias de revista...

"Eles tentam trazer para o lugar a vida que eles idealizam.

In: LYLE, John T. Design with human ecosystems, p. 204.

\begin{tabular}{|c|c|c|}
\hline 140 & Palsagem & São Paulo n. 11 p. 131202 dez. 1998 \\
\hline & $\begin{array}{l}\text { Ensalos } \\
11\end{array}$ & \\
\hline
\end{tabular}




\section{PASAGET ORIGINAL}
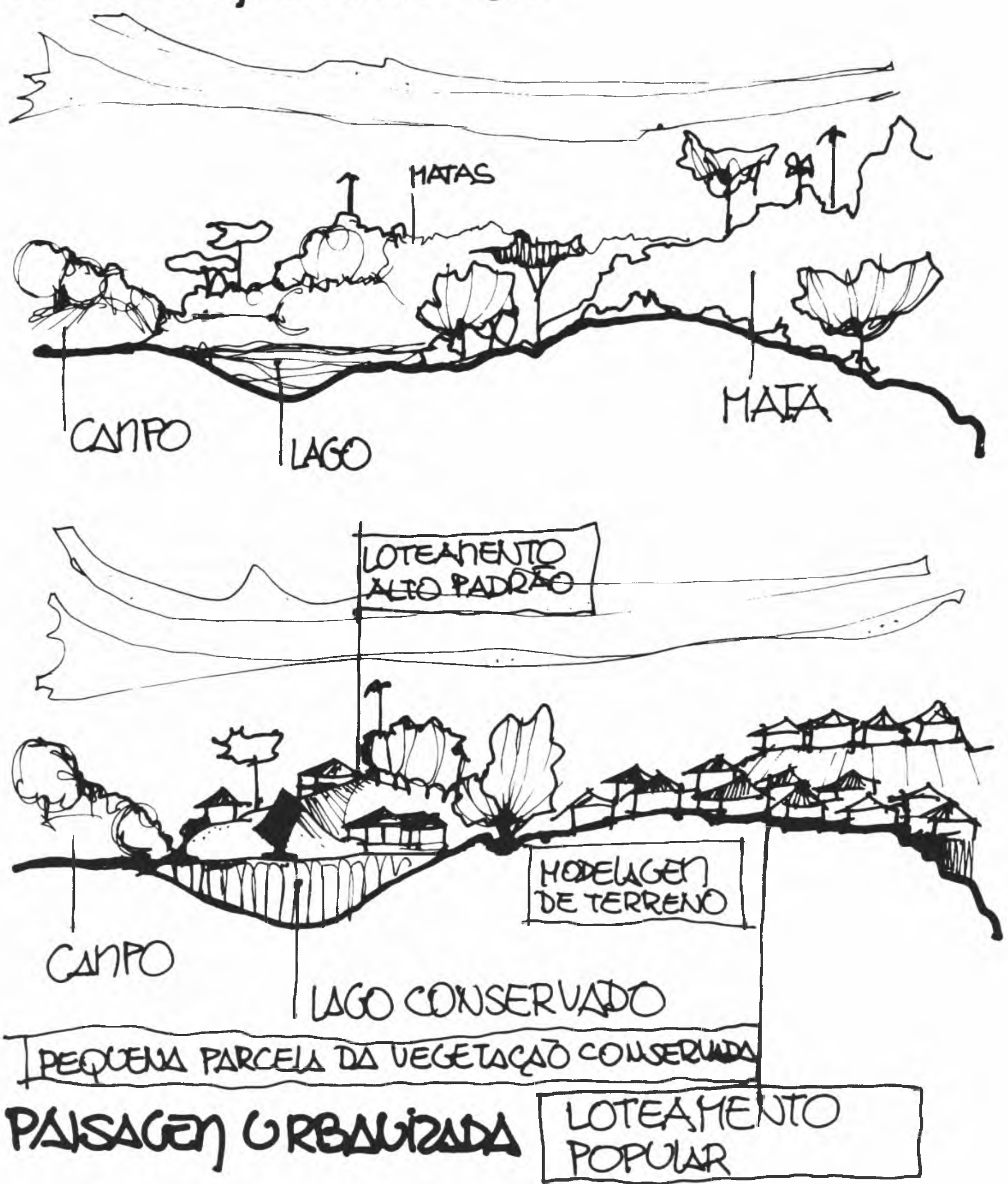

Mesmo nos empreendimentos de alto padrão, os graus de processamento são muito grandes, pois para a construção dos arruamentos, dos generosos equipamentos coletivos, dos lagos e 
Sílvio

Soares

Macedo

jardins de efeito cênico e a abertura dos lotes transforma-se drasticamente o ambiente. As mudanças não são necessariamente tão dramáticas quanto as efetuadas nos loteamentos populares, já que parte dos recursos paisagísticos existentes, como águas e pequenos bosques, são muitas vezes conservados e utilizados como componentes do cenário em construção.

De qualquer modo, tanto em um como em outro caso, a paisagem local é sempre submetida a um modelo rígido de desenho que, ao imprimir a ela o caráter urbano do bairro-jardim, causa sempre perdas reais dos valores paisagísticos e ambientais da região.

Toda e qualquer urbanização traz mudanças ao ambiente original, mas pode-se afirmar que destes padrōes convencionais de tecido urbano são altamente incompatíveis com o meio ao vão ser inseridos. Provocam a destruição quase total destes ambientes e exigem a completa reconstrução do local ${ }^{10}$, até mesmo da vegetação. As imagens a seguir mostram claramente este processo em uma área residencial típica de São Paulo.

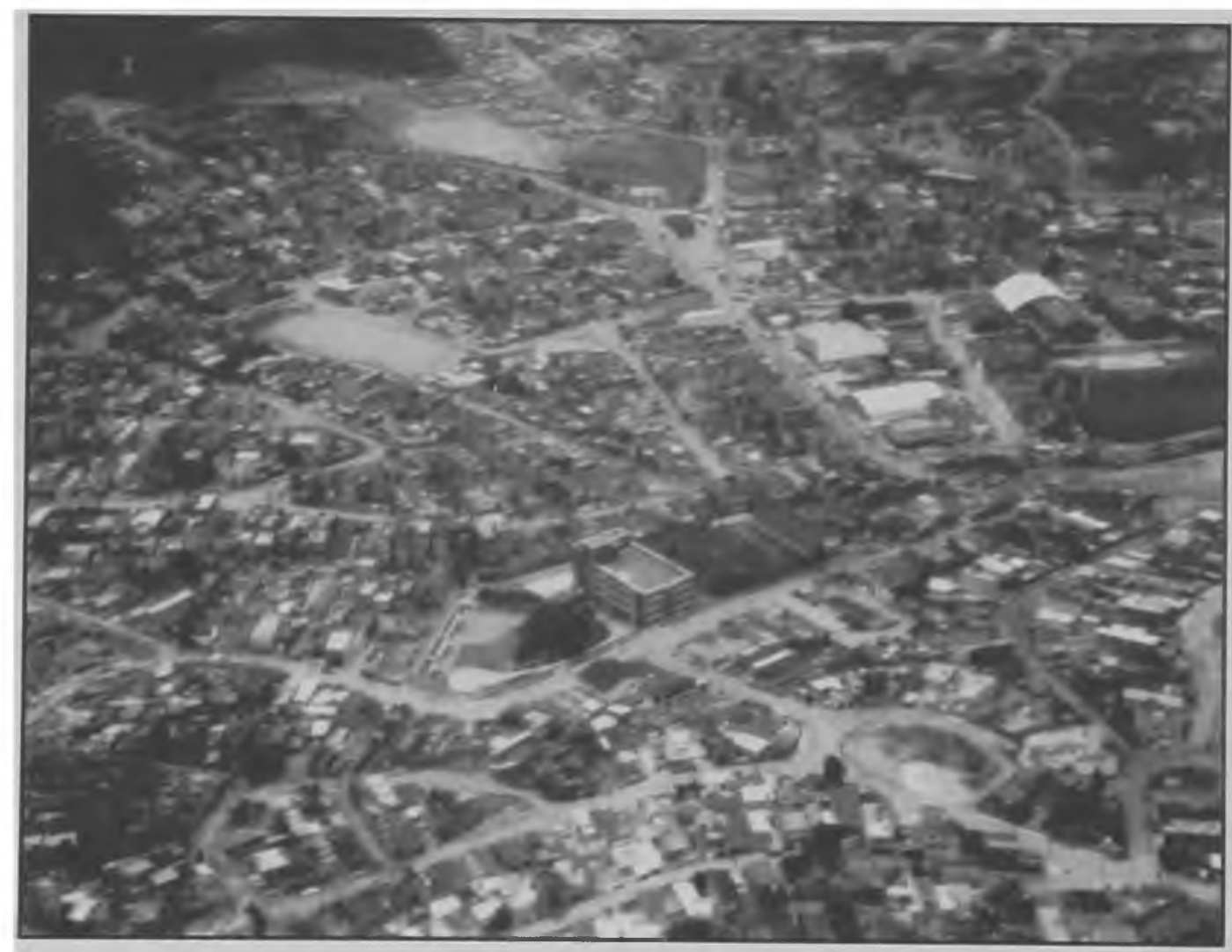

Vista de trecho da zona sudoeste da cidade de São Paulo, vizinho ao Parque do Estado (à esquerda da foto). A foto apresenta o resultado do processo de "destruição reconstrução" da área, no qual a vegetação primitiva foi totalmente erradicada e o espaço remodelado pela sociedade Foto: Sílvio Soares Macedo

(10) "Entendemos o tecido como organizaçāo de elementos urbanos cujo conjunto constitui uma zona urbanizada."

In: MAGNOLI, Miranda Martinelli. Espaços livres e urbanização - Uma introdução a aspectos da paisagem metropolitana. p. 67

\begin{tabular}{|c|c|c|}
\hline 142 & Paisagem & São Paulo n. 11 p. 131202 dez. 1998 \\
\hline & $\begin{array}{l}\text { Ensaios } \\
11\end{array}$ & \\
\hline
\end{tabular}



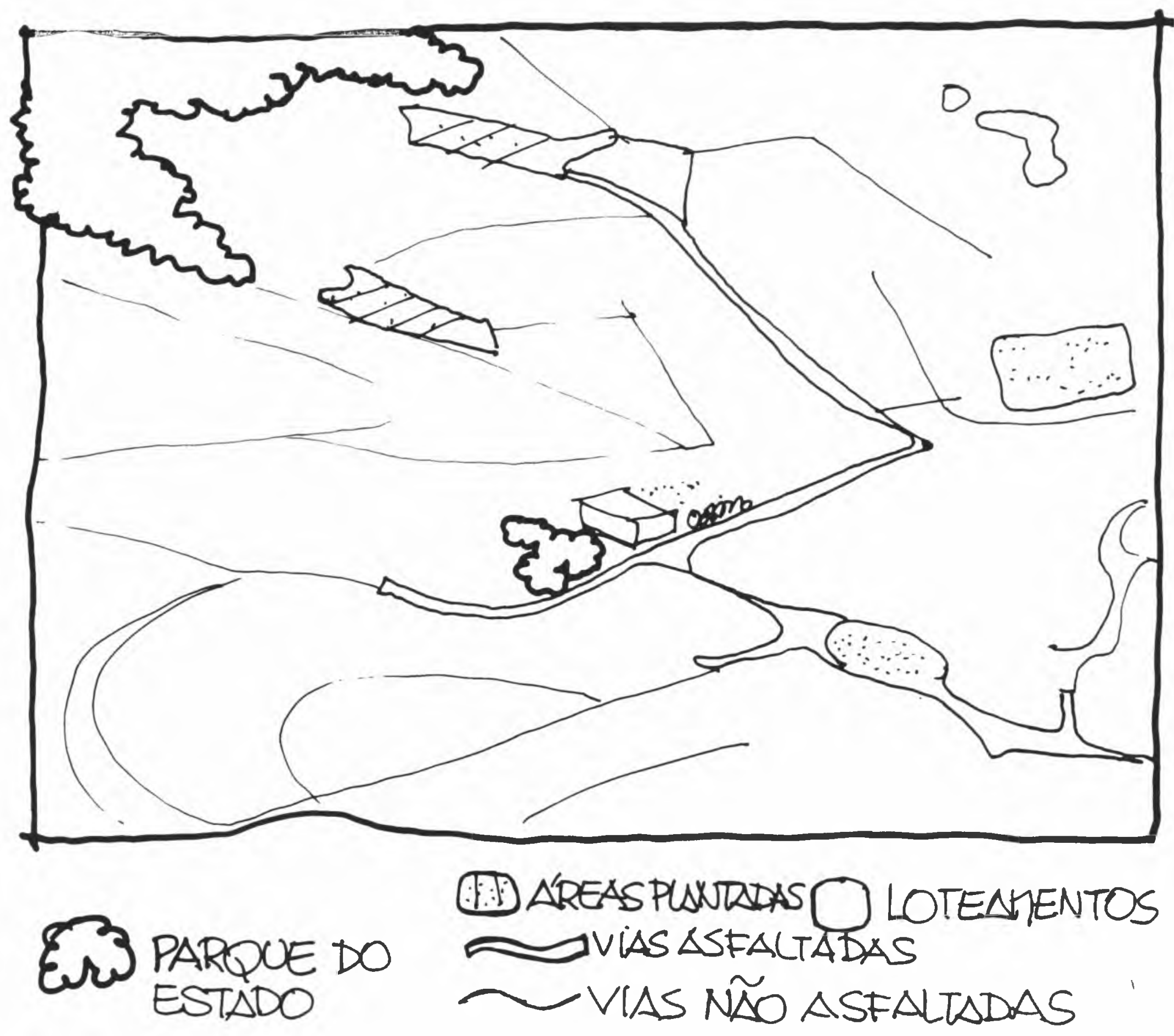

Esta incompatibilidade entre o modelo de urbanização e o meio existente se deve ao fato da malha urbana tradicionalmente implantada - seja ela reticulada ou curvilínea - exigir, tanto pelas técnicas utilizadas pelos empreendedores, como pelos partidos de projeto utilizados, uma grande modelagem do terreno.

Para consolidação deste processo (ao fim do qual o solo está todo impermeávell é necessária a erradicação da vegetação nativa e a transformação e controle significativos na drenagem, ou seja, uma grande alteração do suporte físico e da cobertura vegetal existente.

Mesmo as áreas públicas de lazer criadas (praças ou pequenos parques) raramente incorporam a vegetação nativa, pois sāo construídas sobre situações já altamente processadas pela urbanização. Nestes casos, 
dificilmente a vegetação nativa não foi totalmente erradicada, com a conseqüente e definitiva perda de estruturas de alto valor ecológico e paisagístico ${ }^{11}$

\section{Estas eventuais exceçōes em praças, parques e até em alguns loteamentos mostram que existem possibilidades reais, tanto projetuais quanto econômicas, de se aproveitar os recursos naturais já presentes em assentamentos humanos, inclusive em áreas urbanas densamente povoadas.}

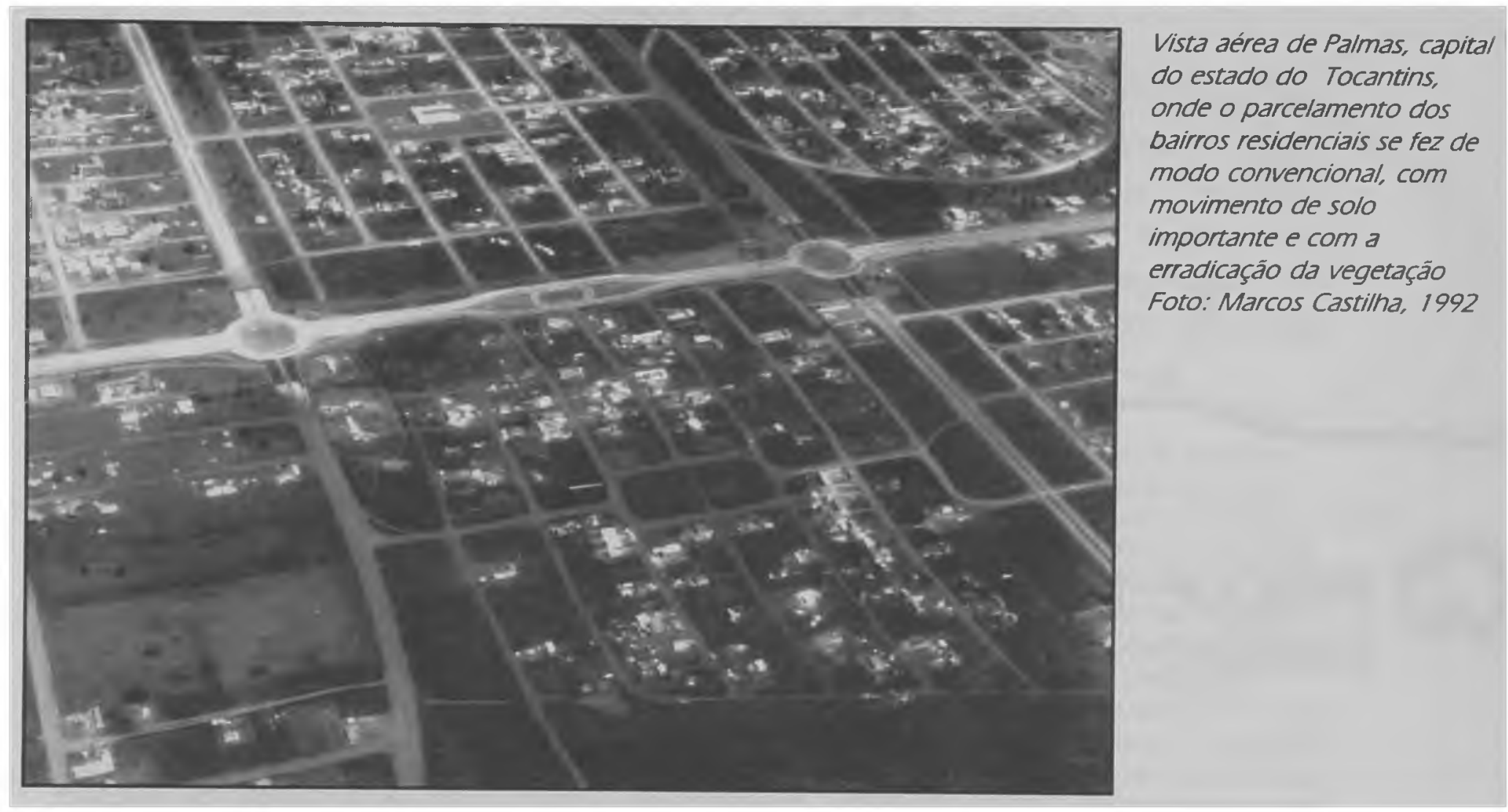

11 1) Fugindo a estes padrōes tradicionais, todo o sistema de parques de Curitiba (Paraná) foi implementado sobre remanescentes de bosques de araucárias e muitos de seus parques lineares conservam a arborização lindeira aos cursos d'água, do mesmo modo alguns dos parques municipais criados na década de 70 em Sāo Paulo, como o Bosque do Morumbi e o Parque da Previdência, no município do mesmo nome e o Parque do Pedroso em Santo André, foram implantados sobre antigos remanescentes de Mata Atlântica.

"Estes assumem formas diversas a partir da consolidação do edifício isolado no lote como modelo urbano. variando sua configuração de acordo com o momento histórico e seus valores sociais, mas mantendo mais ou menos os mesmos programas de uso - o jardim ou pátio - como áreas social e de lazer e o quintal ou área de serviço, destinado a atividades domésticas ao ar livre.

Chão limpo batido de terra, as plantas, suas flores e frutos, fartos por toda a redondeza só entravam na cidade para satisfazer a necessidade ou o gosto do dono de alguma propriedade.

In: MARX, Murilo. Cidade brasileira, p. 67

"Apesar da importância da paisagem verde para o bem-estar do povo ser há muito tempo reconhecida, a reação humana perante as paisagens não tem permanecido a mesma na história."

In: LYLE, John T. Design with human ecosystem, p. 208. 
As alterações se manifestam em todos os sentidos e o próprio modelo de bairro-jardim, que se difunde pelo país é uma simplificação dos originalmente construídos em São Paulo pela Cia. City. Nos exemplares implantados posteriormente, muitos não possuem mais malhas dotadas de um sistema sinuoso de vias e as praças e jardins públicos são drasticamente eliminados, resumindo a figura original à casa isolada no lote, com amplos espaços livres privativos, e as ruas arborizadas.

Nas áreas litorâneas estas simplificações são extremamente freqüentes, pouco restando do modelo original.

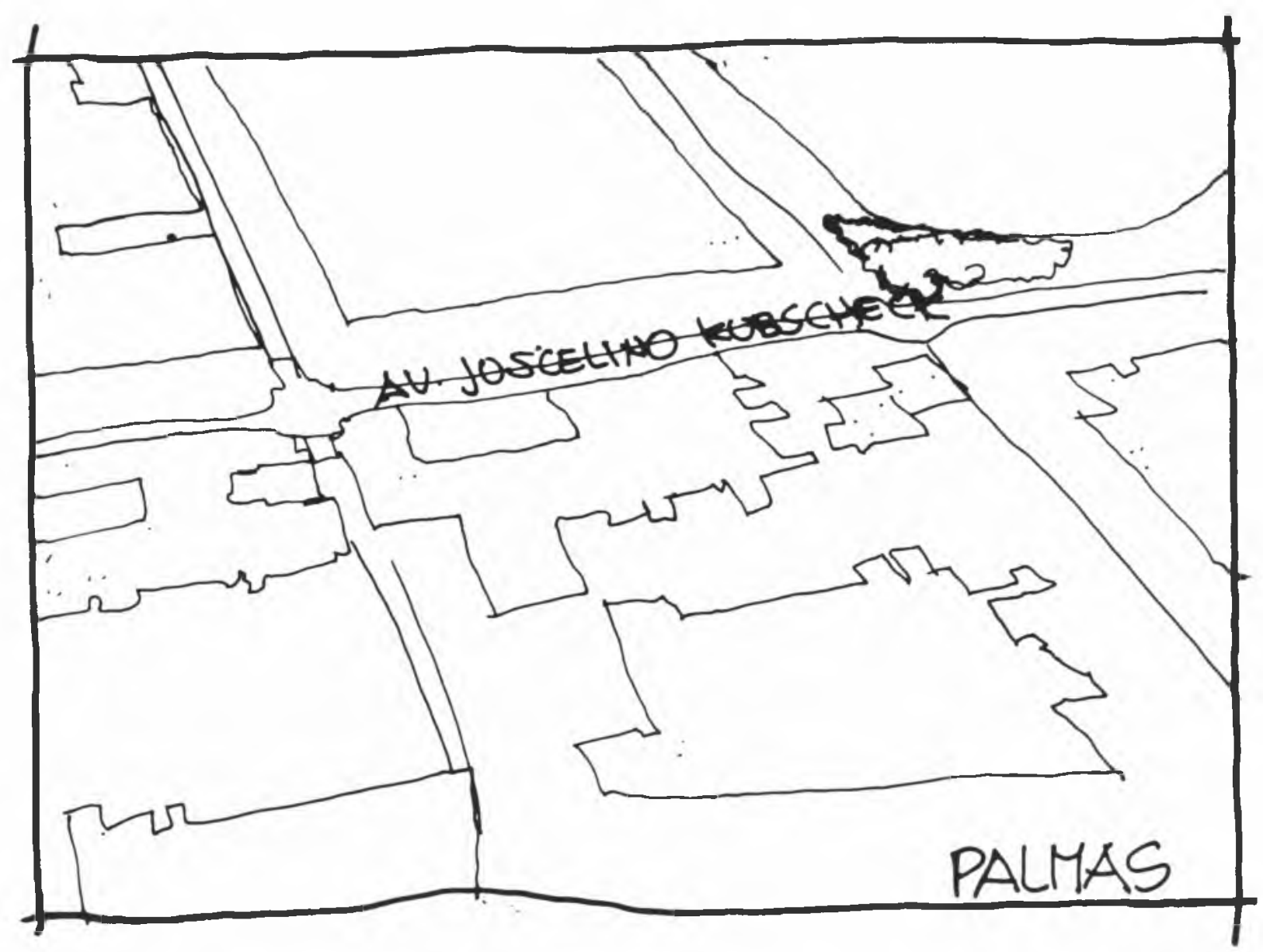

\section{I áreas processadas s/vegetagego GS ÁREAS AINDA CNUEGETACZOO NATINA} A'REAS DE LOTES-EI PROCESSO DE imPERMEABILIZSCAÓ E AJAPDINAMENTO 

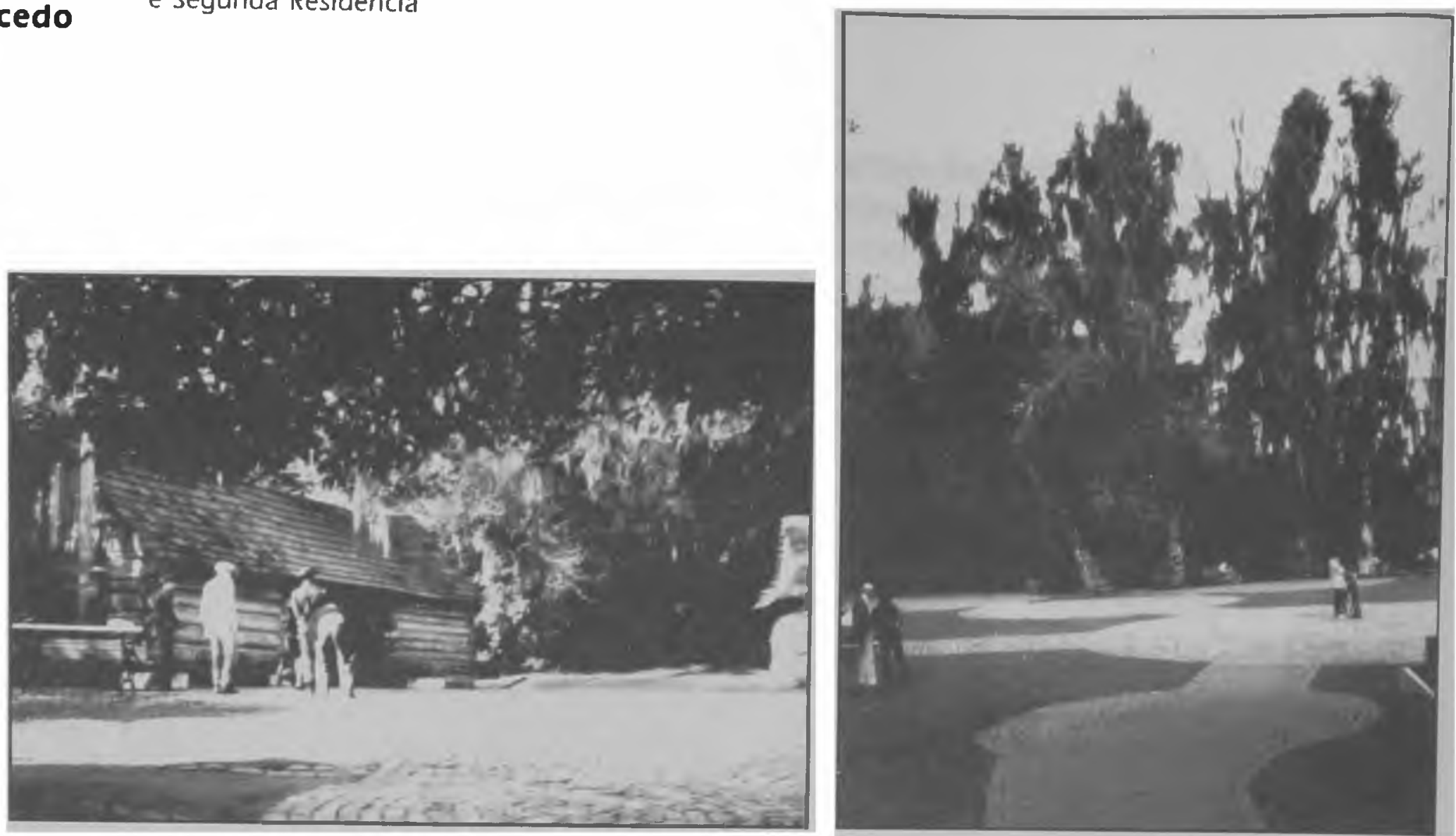

O Parque João Paulo ll, na área central de em Curitiba, é um bom exemplo de projeto de paisagismo elaborado com a vegetação nativa

Fotos: Sílvio Soares Macedo

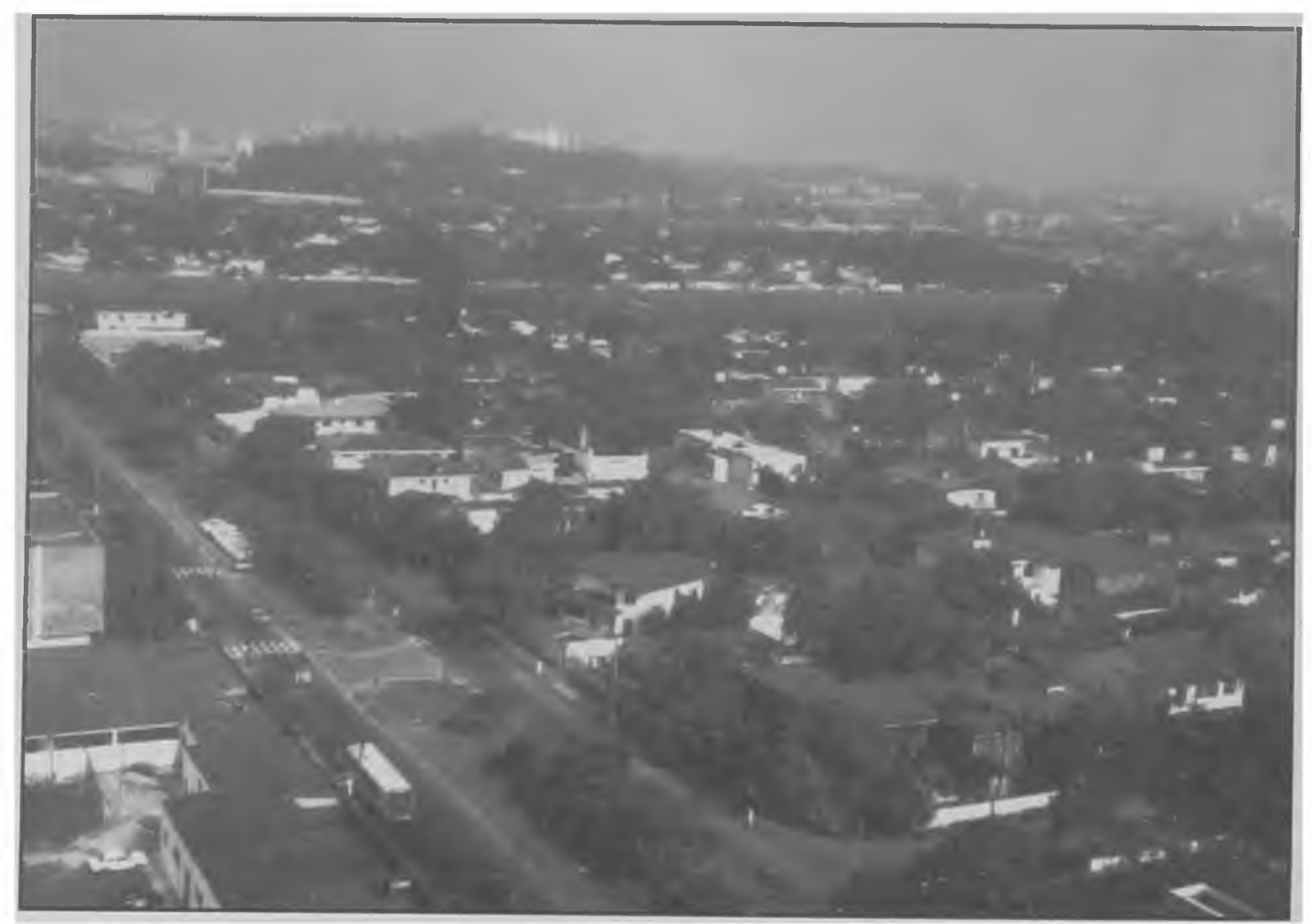

Vista geral do bairro Alto de Pinheiro, um dos últimos bairros-jardins a ser construido em São Paulo, que como seus congêneres apresenta grandes lotes, muita arborização e largas calçadas gramadas Foto: alunos AUP-222, 1992. Arquivo GDPAFAUUSP 


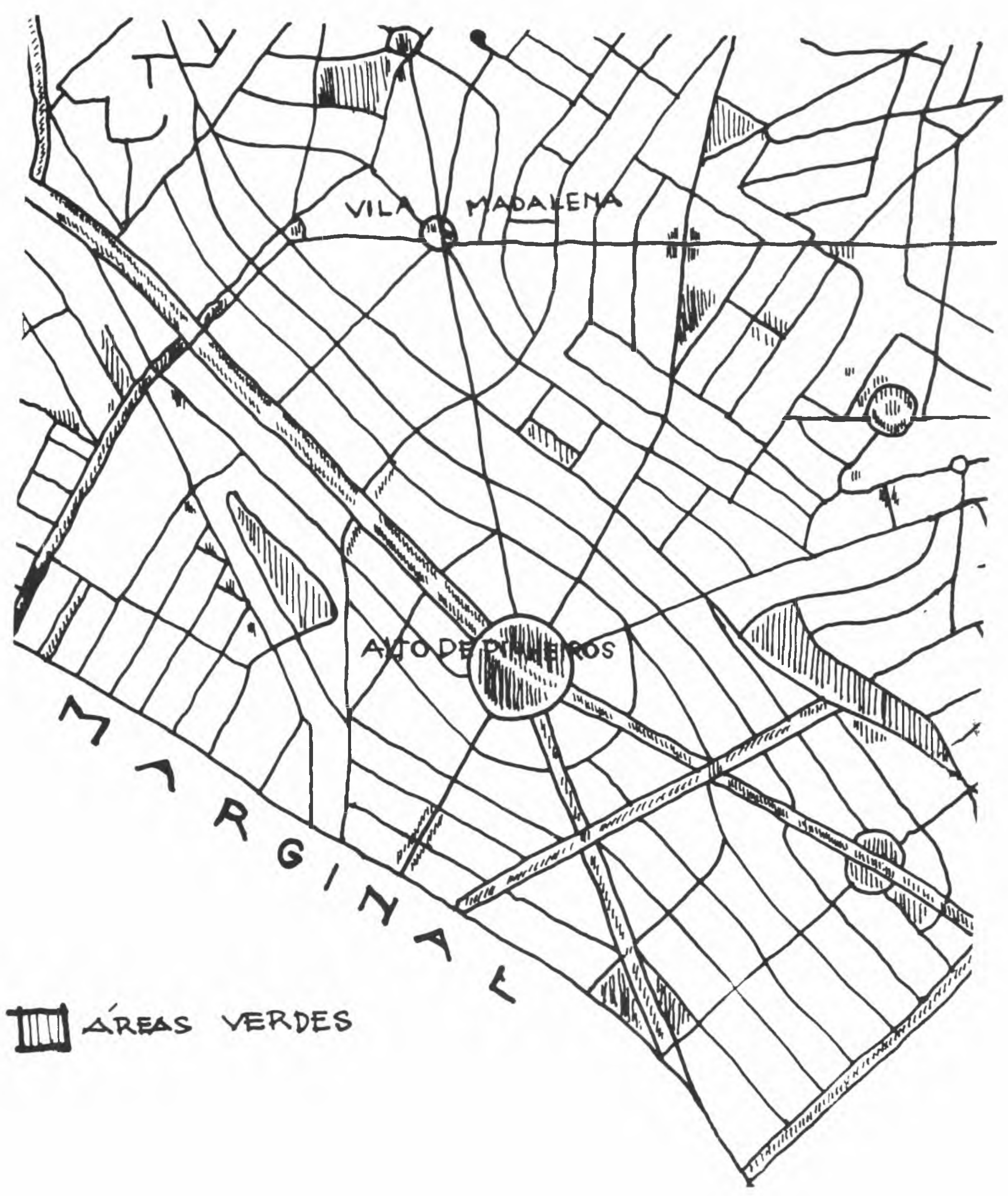


Sílvio Paisagem, Modelos Urbanísticos e

Soares as Áreas Habitacionais de Primeira

Macedo

e Segunda Residência

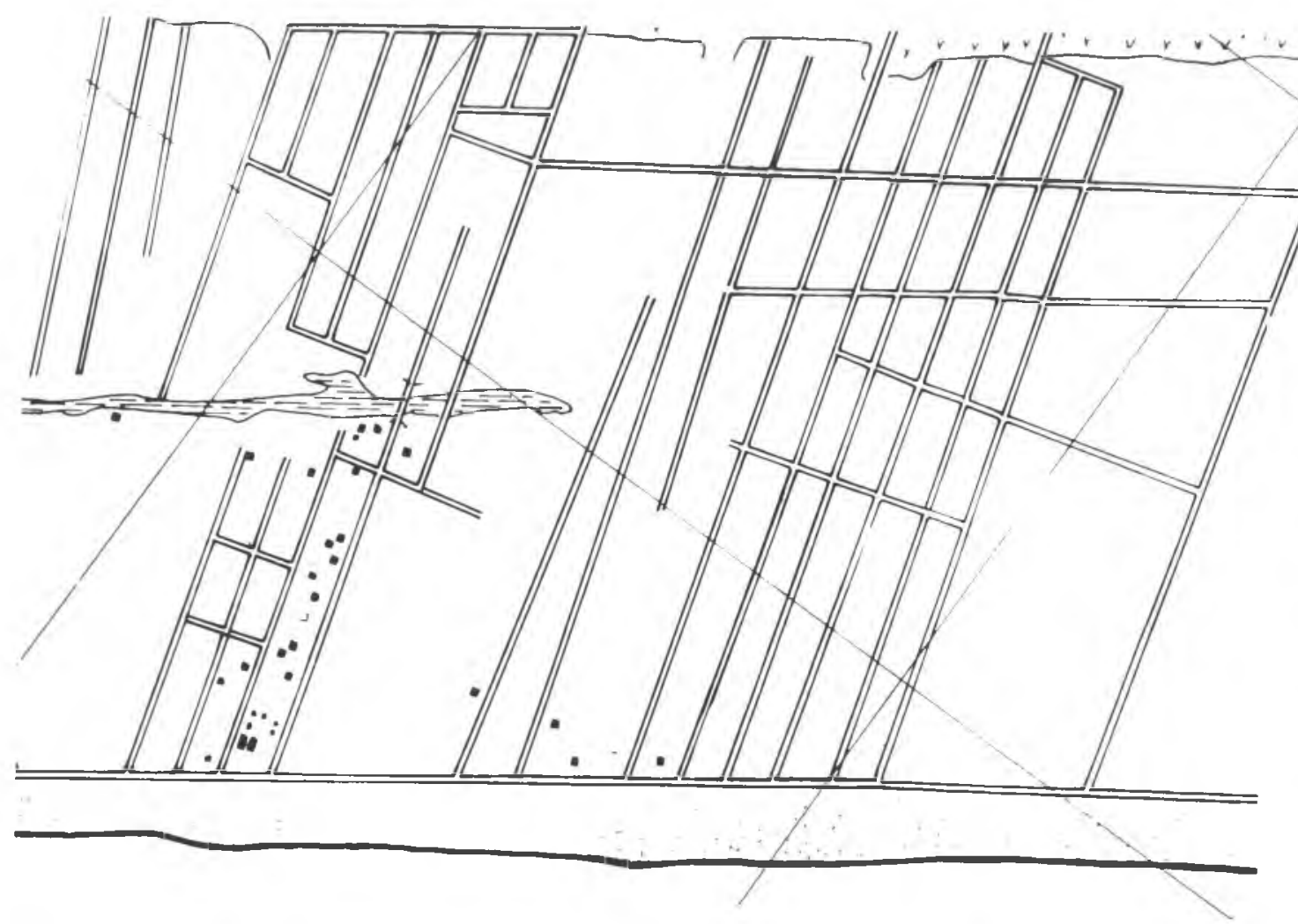

$\circ$

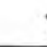

12

2

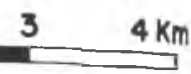

$\|$ A ARRUAMENTOS ABERTOS

$\square$ PRAIA

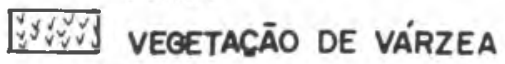

ALAGADICOS

TANGUE

...* edificacōes

ILHA COMPRIDA ( SP - SUL) LOTEAMENTOS IMPLANTADOS

FONTE: SEMPLA 89

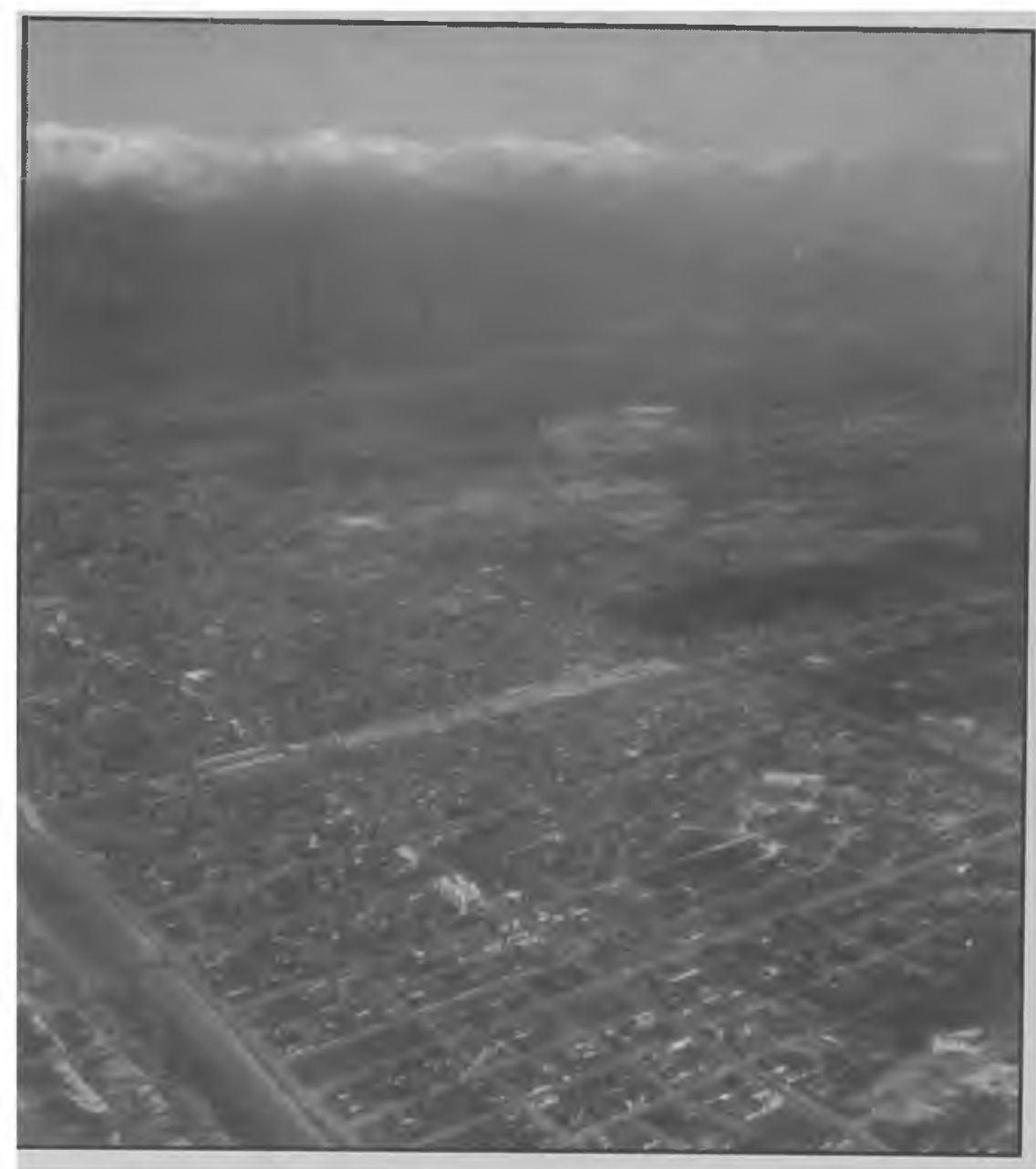

Iguape - loteamento em fase inicial de implantaçāo Foto: Silvio Soares Macedo

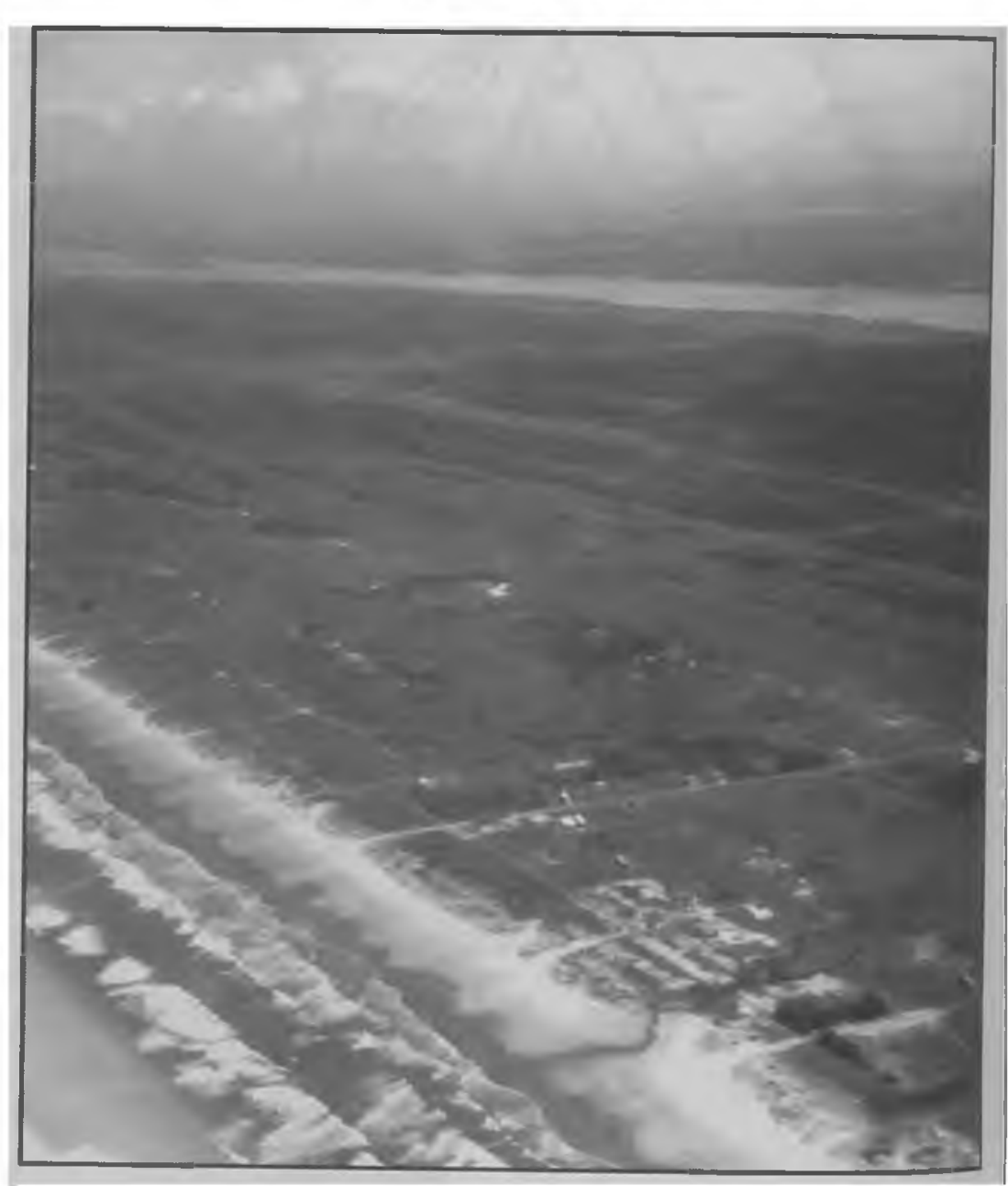

Vista geral da ocupação padrāo de uma área turística costeira - Iguape, São Paulo

Foto: Silvio Soares Macedo 


\section{4 vegetação e as formas de assentamento de carāter habitacional}

O conceito do bairro-jardim incorpora a presença da vegetação ao ambiente urbano de forma generosa, seja no tratamento de seus espaços livres, tanto públicos quanto privados. Nestes casos, a vegetação utilizada é a "urbanizada" - adquirida e criada em viveiros onde é processada para estar de acordo com padrões estéticos aceitos pela sociedade.

O elemento nativo ou natural - em especial a mata típica do país - é tradicionalmente considerado como uma estrutura perniciosa, um mato que deve ser limpo e extirpado e da qual só algumas espécies sāo assimiladas e utilizadas no tratamento dos jardins ${ }^{12}$

Sāo raros os casos de empreendimentos imobiliários /de caráter habitacional ou nãol ou proprietários individuais que tenham privilegiado a existência da vegetação nativa na urbanização de sua propriedade, sendo esta idéia de convívio e conservação dos elementos preexistentes restrita a uma pequena parcela da sociedade.

Normalmente dá-se preferência ao uso dos gramados, arbustos floridos e árvores com disposições preestabelecidas que mais facilmente configuram o ideal estereotipado de jardim. As imagens a seguir mostram uma destas exceções, a residência de $D$. Nininha Magalhães no bairro da Gávea, Rio de Janeiro, onde o jardim tradicional se funde e interage com a mata pertencente à propriedade, formando um todo homogêneo. O espaço tem um belo projeto (de Roberto Burle Marx) e um proprietário com recursos que garantem a sua existência com uma esmerada manutenção.

\footnotetext{
(12) "Era então uma massa florestal impressionante dominada por árvores cuja altura sobrepassa os 50 metros, como jequitibás.

"Sua expressão paisagística era de tal força que a estratégia dos desbravadores era destruí-las, pelo machado e pelo fogo, criando áreas de segurança desvegetadas, afastando índios, animais ferozes e peçonhentos e micropredadores (mosquitos, mutucas, etc.).

"Esses temores, transmitidos de geração a geração, passaram ao inconsciente coletivo das populações que o sucederam, criando contigentes de brasileiros dendrófobos, para quem a devastação é tida como sinônimo de desenvolvimento, numa visão terrivelmente distorcida e danosa aos interesses da naçāo brasileira."

In: MELO FILHO, Luis Emygdio. A floresta Atlântica em Floresta Atlântica, p. 18.
}

\begin{tabular}{|l|ll|l|l|}
\hline São Paulo n. 11 p. $131 \quad 202$ & dez. 1998 & $\begin{array}{l}\text { Paisagem } \\
\text { Ambiente }\end{array}$ & 149 \\
\cline { 3 - 4 } & Ensaios \\
11 & \\
\hline
\end{tabular}




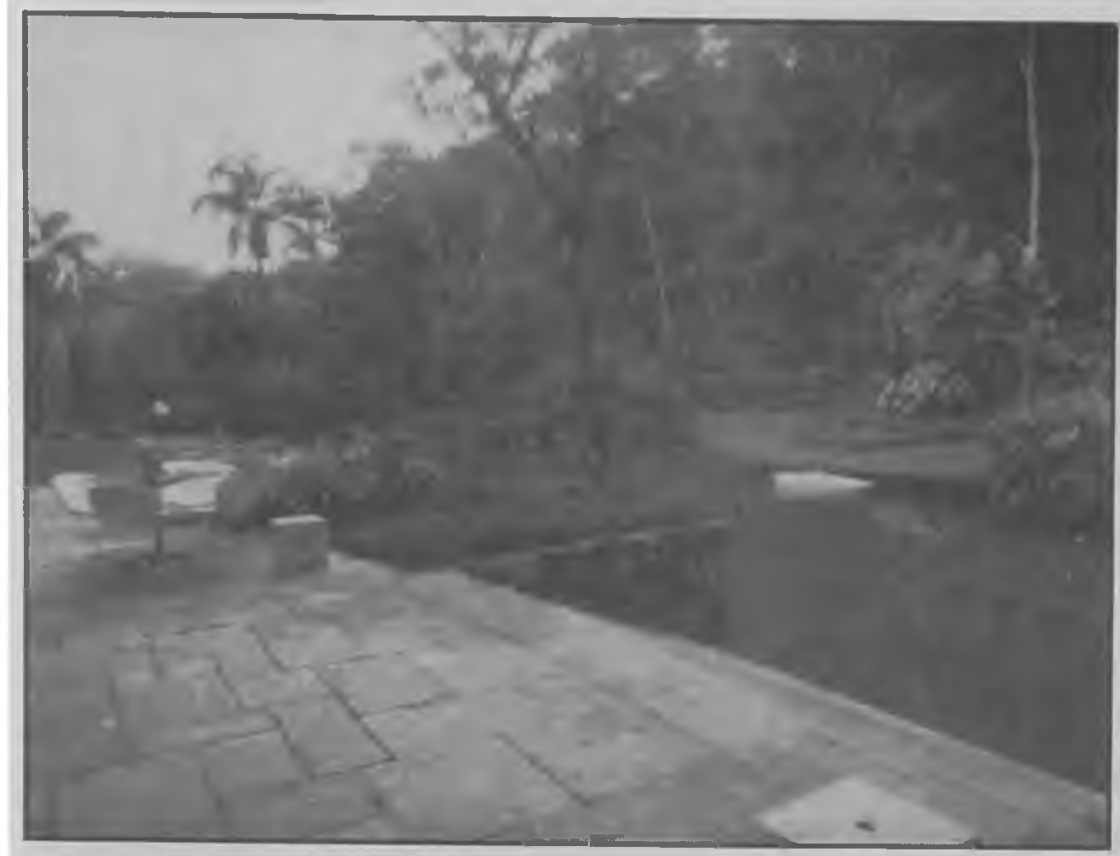

Pequeno lago formado pelo represamento das águas de um riacho Foto: Sívio Soares Macedo

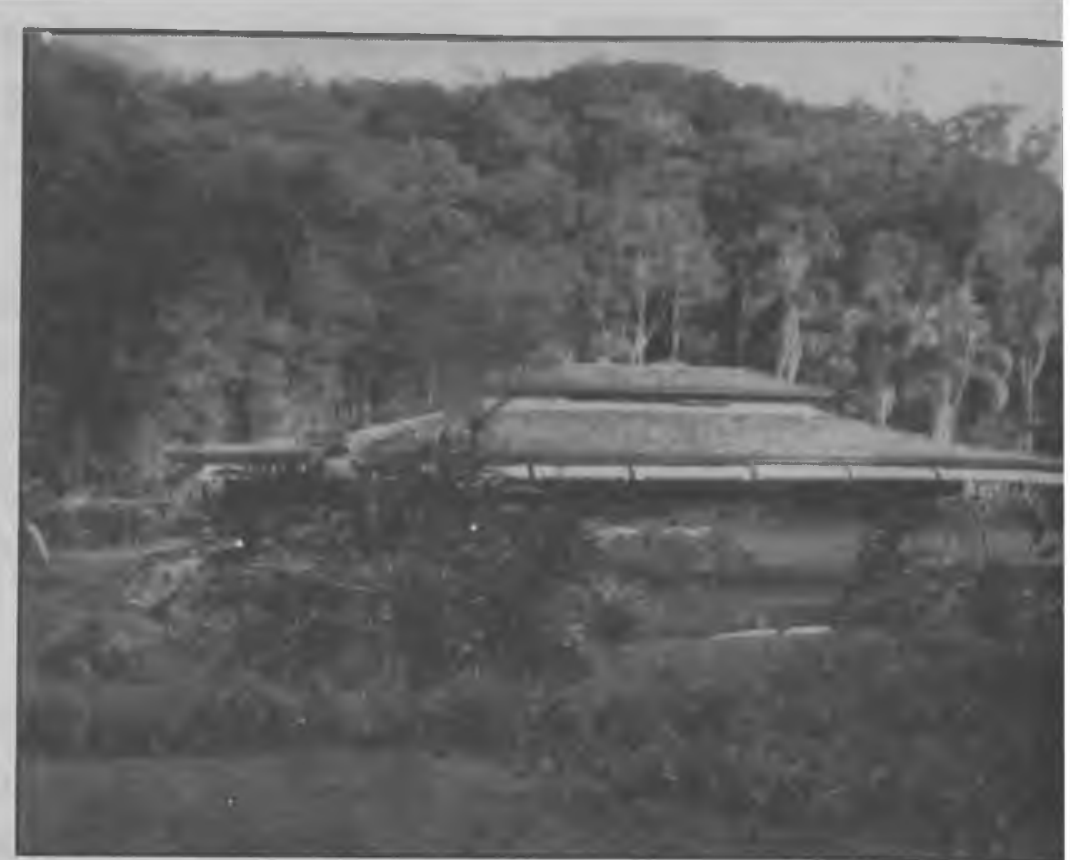

Foto: Arquivo Projeto MUB

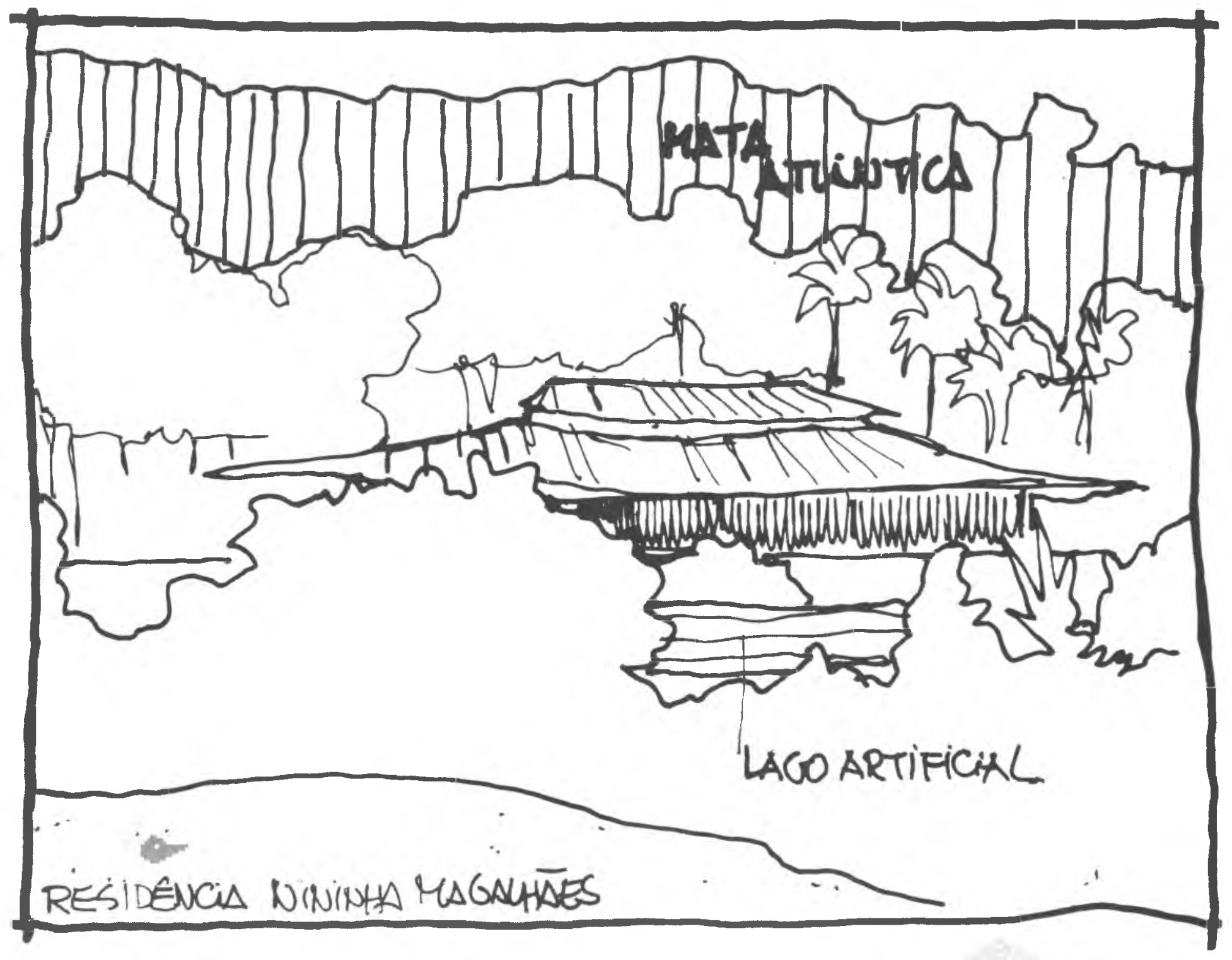


Não é pequeno o número de projetos que, apesar de vulgarmente considerados como "ecológicos" por conter muito "verde", não passam de assentamentos urbanos dotados de amplas e generosas áreas arborizadas, mas que para serem implantados, exigiram a destruição de recursos florestais significativos. É o que nos mostra, a seguir, um caso no litoral norte do estado de São Paulo.

As imagens mostram o condomínio Costa Verde-Tabatinga, em Caraguatatuba, que aparentemente poderia ser considerado como "ecológico". As edificações estão implantadas em meio a uma luxuriante vegetação (totalmente plantada), de modo a construir um jardim urbano com amplos gramados e alamedas. A vegetação antes existente, muito densa e típica de mata de restinga, foi totalmente extirpada para possibilitar a construção dos jardins tão típicos dos empreendimentos convencionais.

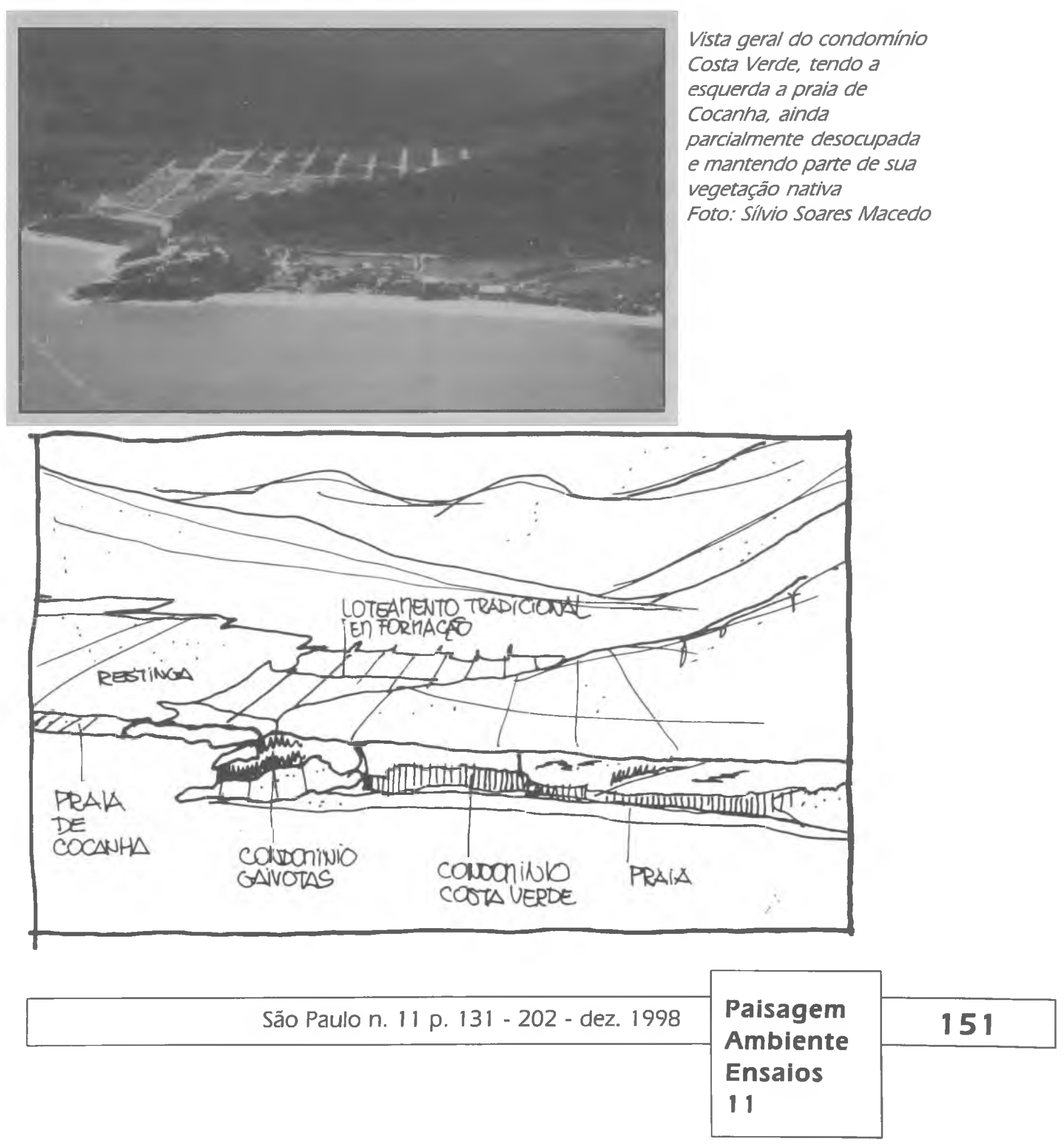




\section{(O) modelos de loteamento e o litoral - início e evolução}

Apesar da urbanização das áreas costeiras no Brasil, remontar ao início da ocupação territorial do país ${ }^{13}$ foi somente no início do século 20 que o loteamento de trechos significativos da orla marítima passa a ser socialmente aceitos como uma figura urbana. Podemos dizer que a abertura do bairro de Copacabana na cidade do Rio de Janeiro é um marco deste processo ${ }^{14}$

O bairro possui uma malha em xadrez adaptada à enseada na qual se localiza e se organiza em função de duas vias principais paralelas entre si; uma bordejando a praia (avenida Atlântica) e a outra interna (avenida Nossa Senhora de Copacabana), às quais estão perpendiculares ou paralelas às demais vias.

Copacabana era a princípio um subúrbio carioca; um bairro distante onde veraneavam ou moravam famílias abastadas. Durante a primeira metade do século 20 consolida-se como uma das mais importantes áreas habitacionais do país, tornando-se um padrão de ocupação urbana à beira-mar.

(13) "A cidade brasileira foi fundada, evoluiu e se consolidou na costa mais oriental das américas.

"Trechos da costa foram eleitos para as fundações urbanas em função da sua latitude, das suas possibilidades de abrigo aos navegantes, da sua ligação com o interior, misterioso e desafiante.

In: MARX, Murilo. Cidade brasileira, p. 12, 14 e 15.

(14) Sobre este fato, no Rio de Janeiro, Flávio Villaça faz as seguintes colocações:

"Talvez o fator único, que mais tenha influído na atual estrutura territorial do Grande Rio tenha sido uma transformação de costumes: o surgimento e vulgarização do banho de mar, e a conseqüente valorização da praia como local residencial."

“Nenhum deles (se refere o autor aos bairros de Higienópolis em São Paulo. Vitória e Graça em Salvador e Moinho de Ventos em Porto Alegrel chegou a exercer sobre tantas camadas sociais um fascínio como o de Copacabana. Ocupada no início do século XX por camadas da burguesia, seu prestígio social e sua beleza tiveram rápida divulgação; a preferência daquelas camadas fez com que os serviços públicos e 0 acesso ao bairro como a zona sul em geral fossem aprimorados. Copacabana já estava arruada e loteada pela burguesia e para ela, no terceiro quartel do século passado."

In: VILLAÇA, Flávio. Estrutura territorial da metrópole sul brasileira, p. 157 e 170. 


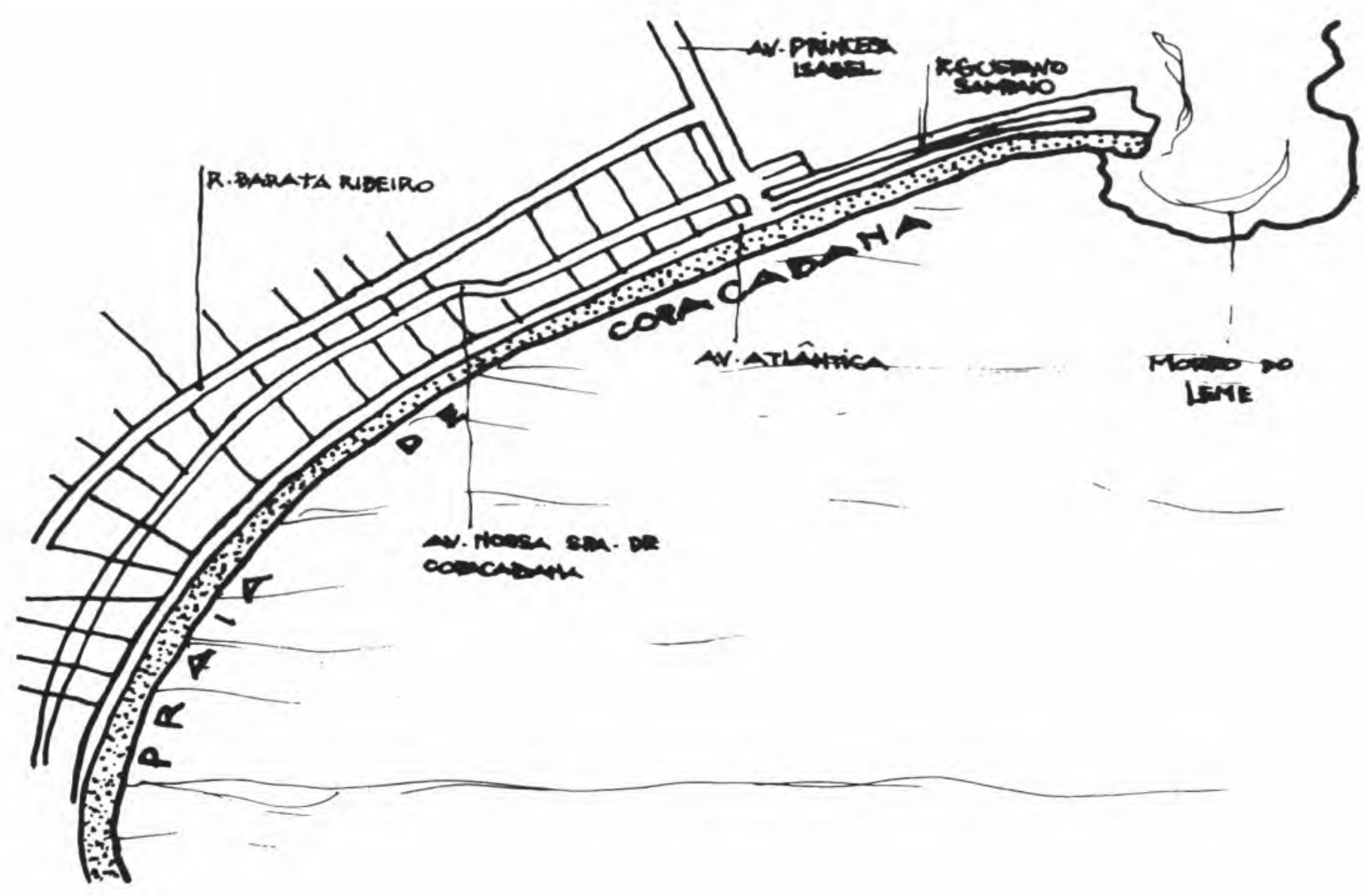

O mar como valor cênico e paisagístico, e a praia como espaço para o lazer, são incorporados nesta época ao repertório urbano brasileiro. Refletiam ideários provenientes do continente europeu e dos Estados Unidos, onde o usufruto das praias já se consolida no final do século $19^{15}$ e início do século $20^{16}$. Esta figura urbana é introduzida na então capital da República, vindo a acarretar a constituição de espaços urbanos similares pelo país.

Possuir um imóvel ou passar as férias em frente ao mar vira sinônimo de status e por todas as cidades de porte - capitais ou não - surgem bairros que foram construídos à semelhança de Copacabana. A via beira-mar transforma-se em pólo aglutinador da população e a praia assume a função urbana do parque, sendo utilizada como centro de lazer por um público amplo.

Juntamente com a consolidação do bairro praiano nas cidades costeiras, semelhantes a Copacabana na sua fase inicial de implantação lentão um bairro constituído por uma volumetria baixa, de residências

(15) "Foi a partir da segunda metade do século XVIII que o homem europeu das classes altas passou a valorizar a emoçāo do banhista, as caminhadas e cavalgadas pela areia, as temporadas de veraneio.

In: CORBIN, Alain. O território do vazio - A praia e o imaginário. Introdução.

O livro em questão mostra as primeiras formas de ocupação e uso da beira-mar pela elite européia nos séculos 18 e 19 .

(16) "Foi um longo período de gestação, que cobre quase dois séculos, da segunda metade do século XVIII até os anos 30, com a eclosāo do turismo popular, registrando-se uma mudança radical do comportamento do homem-lazer, do veranista e da ocupaçāo do espaço do litoral."

In: CAZES, G.; LANQUAR, R.; RAYONARD, Y. - L'aménagement touristique. p. 51. 
Sílvio Paisagem, Modelos Urbanísticos e

Soares as Áreas Habitacionais de Primeira

Macedo

recuadas e isoladas nos lotes), surge uma outra figura urbana, a do loteamento costeiro que, bordejando praias e costões, instala-se e multiplica por todo o país.

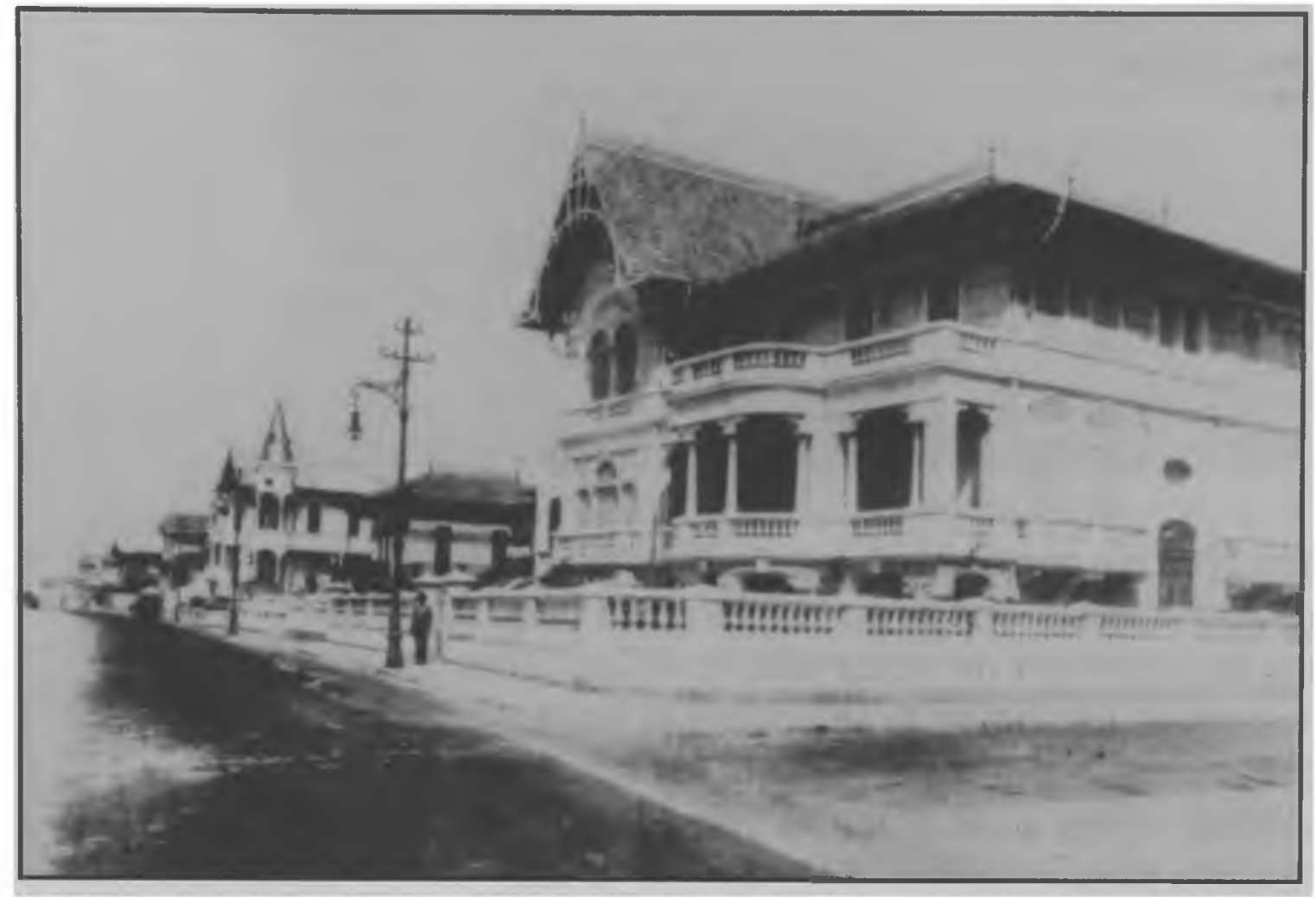

Vista da avenida Atlântica (RJ) no início do século, com as residências isoladas dentro do lote. Foto extraída do livro $O$ Rio de Janeiro em cartóes postais. p. 153 Foto: Sílvio Soares Macedo

\footnotetext{
Vista de Copacabana no início do século 20

O calçađão, obra do prefeito Pereira Passos, estava recémimplantado, junto à figura de avenida beira-mar como se conhece. Foto extraída do livro $O$ Rio de Janeiro em cartóes postais, p. 162. Foto: Silvio Soares Macedo
}

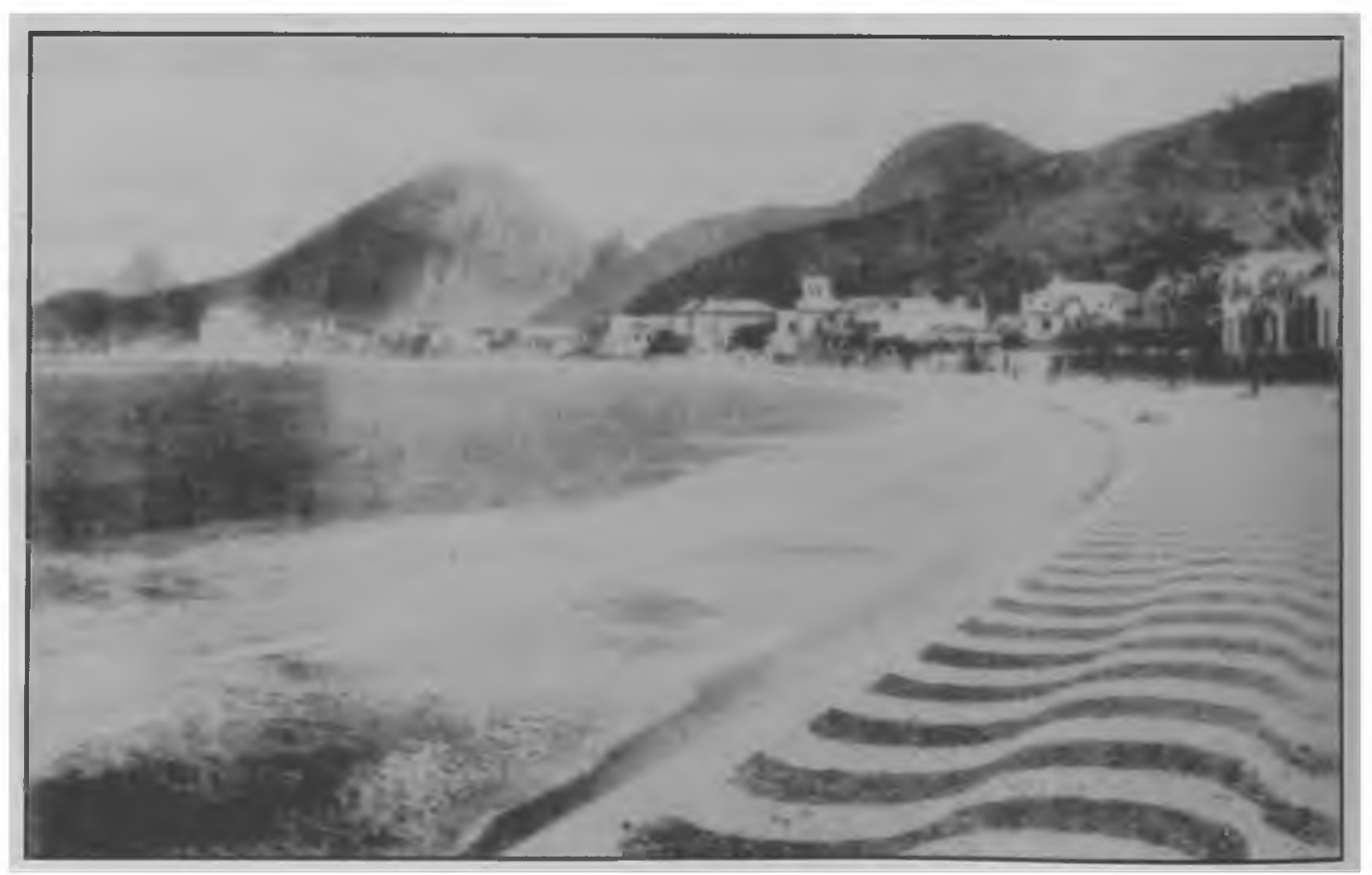


Este tipo de loteamento - ao contrário de bairros como Copacabana ou Icaraí (Niterói) - destina-se predominantemente ao lazer sazonal. O próprio bairro de Boa Viagem (Recife), era até poucos anos atrás uma área destinada a esta finalidade. Esta forma de ocupação é encontrada por todo o litoral, ora constituindo subúrbios distantes de cidades maiores, como por exemplo os bairros de Canasvieiras e Armação em Florianópolis (no estado de Santa Catarina), ora tomando parte da trama urbana de pequenas sedes municipais como Prado ou Alcobaça na Bahia.

Vista aérea de Copacabana. no final dos anos 80 Fotos: Silvio Soares Macedo
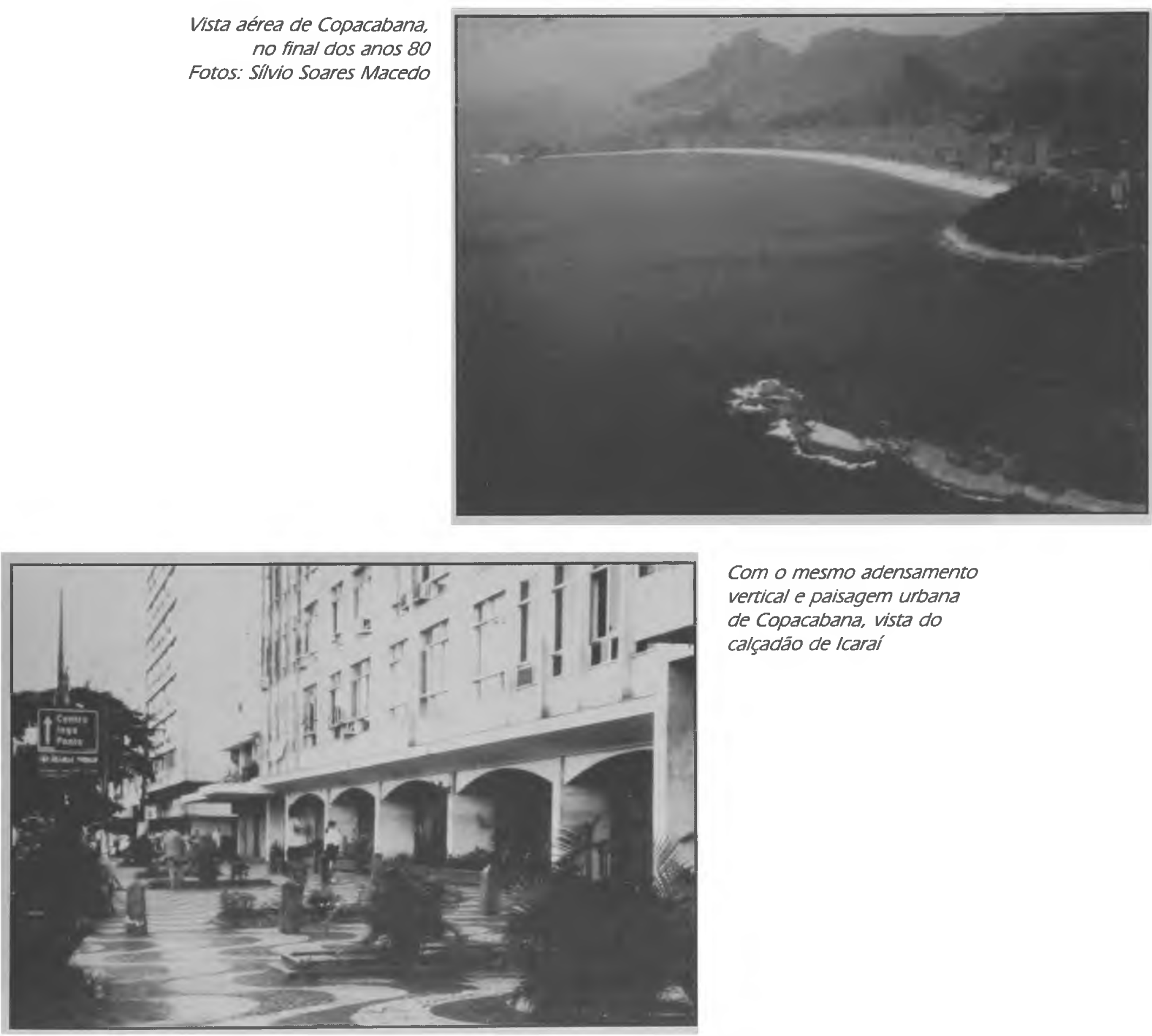

Com o mesmo adensamento vertical e paisagem urbana de Copacabana, vista do calçadão de Icaraí 
Como conseqüência de seu uso exclusivamente sazonal, tais áreas apresentam características próprias, sendo a principal o total desvinculamento de grande parte da sua população de veranistas (donos da maior parte das residências) com o município em que estão instaladas suas propriedades. Muitos destes proprietários residem em municípios distantes do lugar onde possuem sua habitação de veraneio.

Este fato se reflete diretamente na forma de estruturação da trama urbana, que em geral é ineficiente para receber os elevados contigentes de veranistas, que durante o ano multiplicam em muitas vezes a população destas cidades.

As deficiências são muitas: desde a inexistência de serviços de abastecimento adequados de água, até a ausência total de esgotos. Por muitas vezes a vida urbana e até mesmo a economia da cidade e do município estão estruturadas em função exclusiva da temporada de verão.

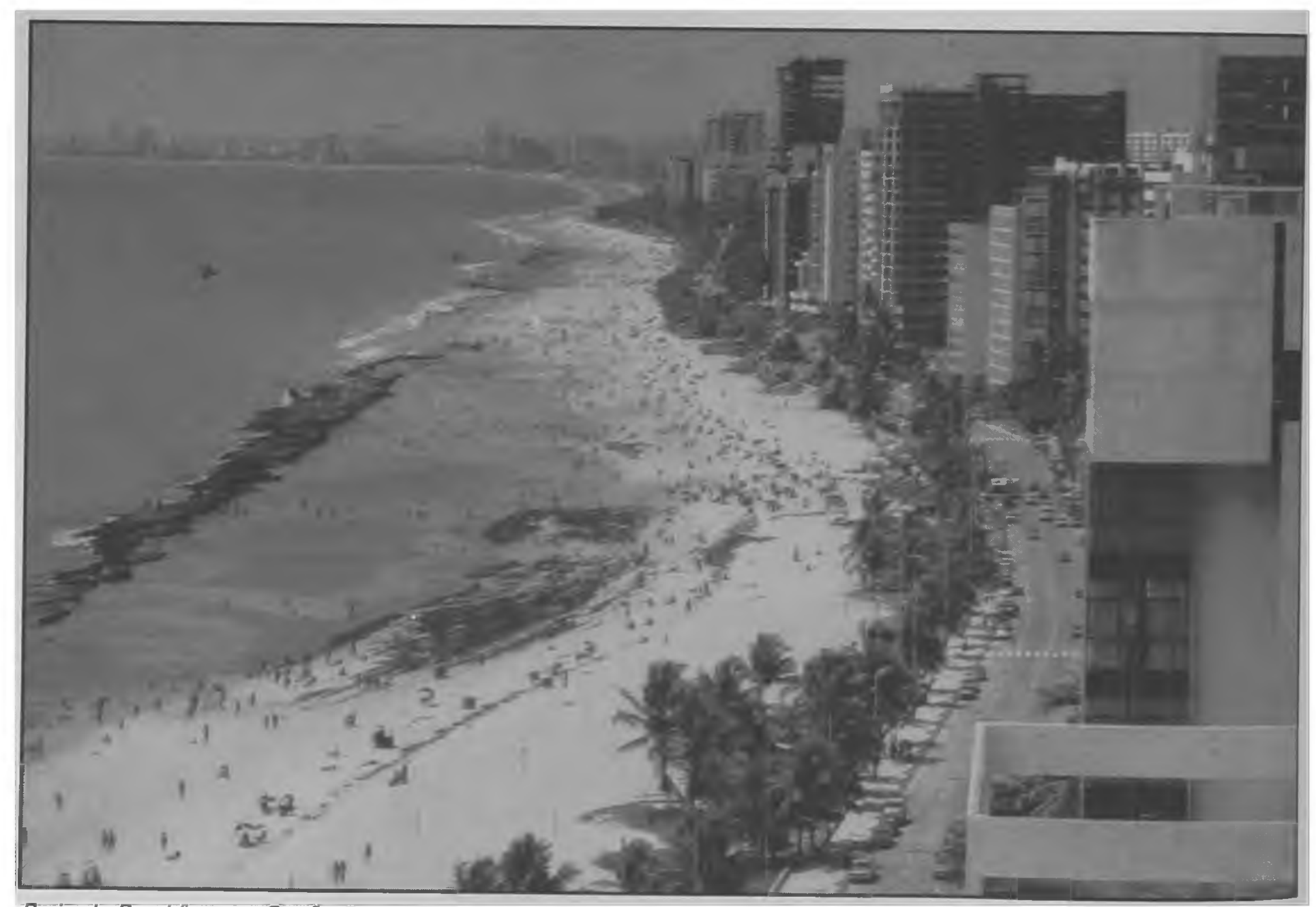

Praia de Boa Viagem. Cartáo Postal

Foto: Arquivo Sívio Soares Macedo 
Por outro lado, poucos são os municípios que conseguem aparelhar suas sedes para atender contingentes tão grandes de população unicamente com a renda advinda deste tipo de turismo. Observa-se, na maioria dos casos, um estado de deficiência crônica em quase todos os setores, que além dos problemas citados, englobam redes viárias precárias, sistemas de espaços livres (se existentes) mal-aparelhados, abastecimento insuficiente...

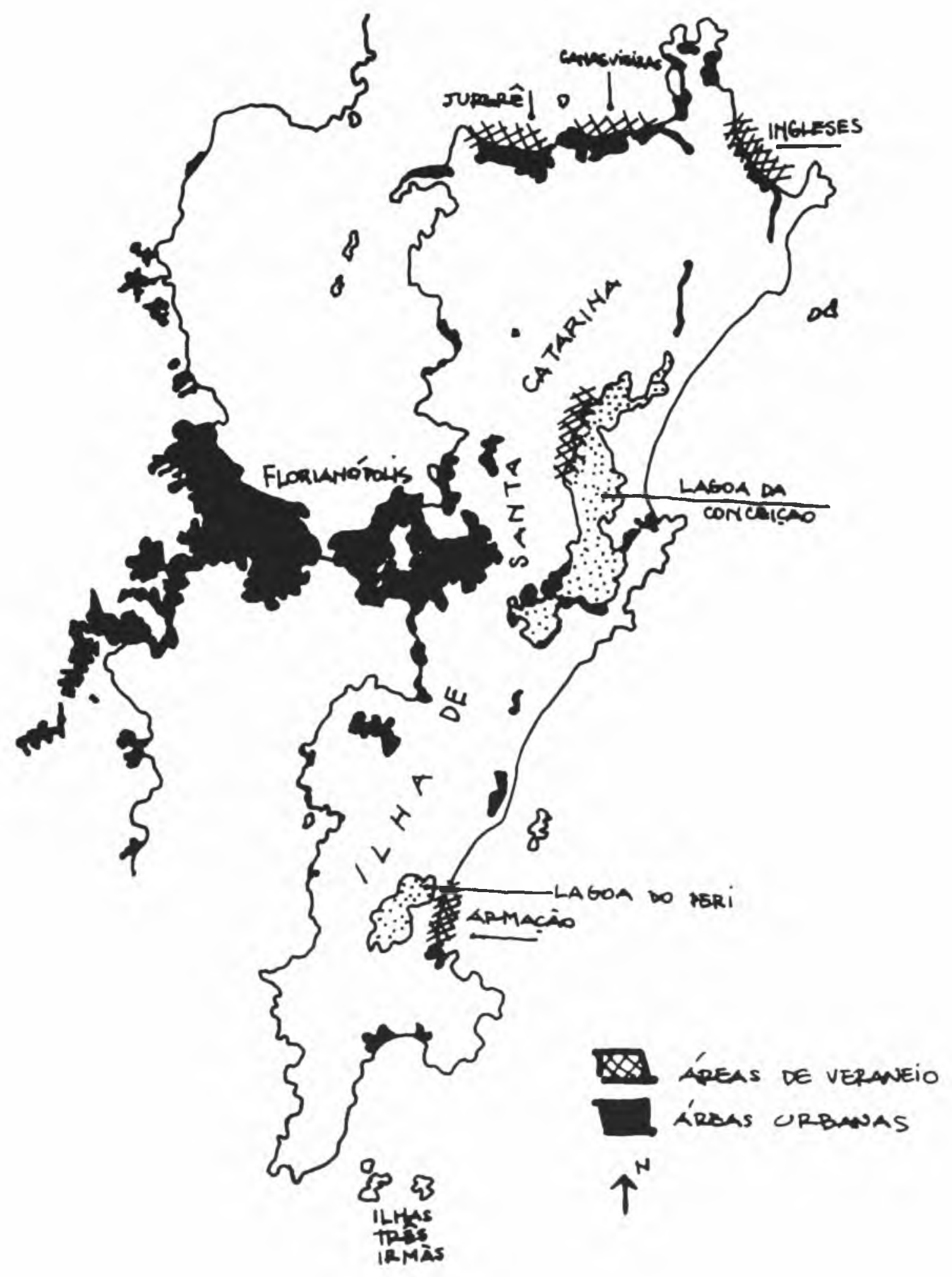


Toda a ocupação é voltada para a exploração máxima dos valores paisagísticos ligados à praia e ao mar, pois estes são os focos de atração deste tipo de ocupação. Em função destes atrativos, vão sendo construídos ao longo da linha da costa, caminhos que servem de apoio ao assentamento dos loteamentos, e que hoje representam um importante papel na indústria imobiliária.

As áreas planas junto às praias apresentam maior facilidade de acesso ao mar e de construção preferidas para a implantação deste tipo de loteamento e somente quando esgotados tais espaços é que se ocupam as áreas mais internas ou os costões. Estes últimos têm grande procura, pois contam com a vantagem da posição a cavaleiro em relação ao oceano e possibilitam belos visuais. Os demais valores paisagísticos e ambientais, como barras de rios, manguezais e matas, não são objeto de atenção imediata nem para o empreendedor, nem para a maioria do público consumidor e são eliminados quando necessário ${ }^{17}$

O grande alvo deste tipo de empreendimento litorâneo são as camadas médias e altas da população. O seu crescimento a partir do surto econômico da segunda metade do século explica a expansão deste ramo do mercado imobiliário, que se expande constantemente, criando novos produtos e abrindo novos campos de atuação.

Esta forma de ocupação se configura, primeiramente a partir dos anos 50 e 60, nos estados do Rio de Janeiro (pela região de Cabo Frio) e São Paulo (principalmente na Baixada Santista) e rapidamente se difunde por todo o país. Três décadas depois espalha-se por quase todo o litoral brasileiro, ocupando áreas extensas, lineares e muitas vezes contínuas.

(17) Sobre a organização espacial das áreas turísticas e dos impactos causados pela sua urbanização, Krippendorf pondera:

"Certamente constataremos que, num grande número de setores, o custo suportado pela sociedade, pela economia e pelo meio ambiente ultrapassa largamente os benefícios alcançados. Esta constataçāo se aplica ao setor de lazer e viagens, como o demonstra o seguinte exemplo: criou-se na maioria das zonas de repouso e das regiões de férias, um mercado de construção que obedece a leis próprias e que se dissociou completamente do turismo. A liquidaçāo do solo, a produção de novos chalés, de apartamentos de férias, de prédios de apartamentos do tipo conjugado, hotéis e outras construçōes prosseguem em ritmo acelerado, e isto muito embora a taxa de ocupação das instalações existentes seja quase sempre fraca e diminua de ano para ano e as paisagens percam cada vez mais sua aparência natural."

In: KRIPPENDORF, Jost. Sociologia do turismo. p. 23 


\section{P adröes de assentamento}

Os loteamentos de praia seguem preceitos' básicos para a sua implantação.

1 Todos se organizam em função de uma via principal de acesso, seja ela uma rodovia ou uma simples via urbana, que pode ou não correr paralela à praia. Em áreas de costões é normal o assentamento ocorrer à medida que o relevo permite, mantendo-se ou não junto a esta via principal;

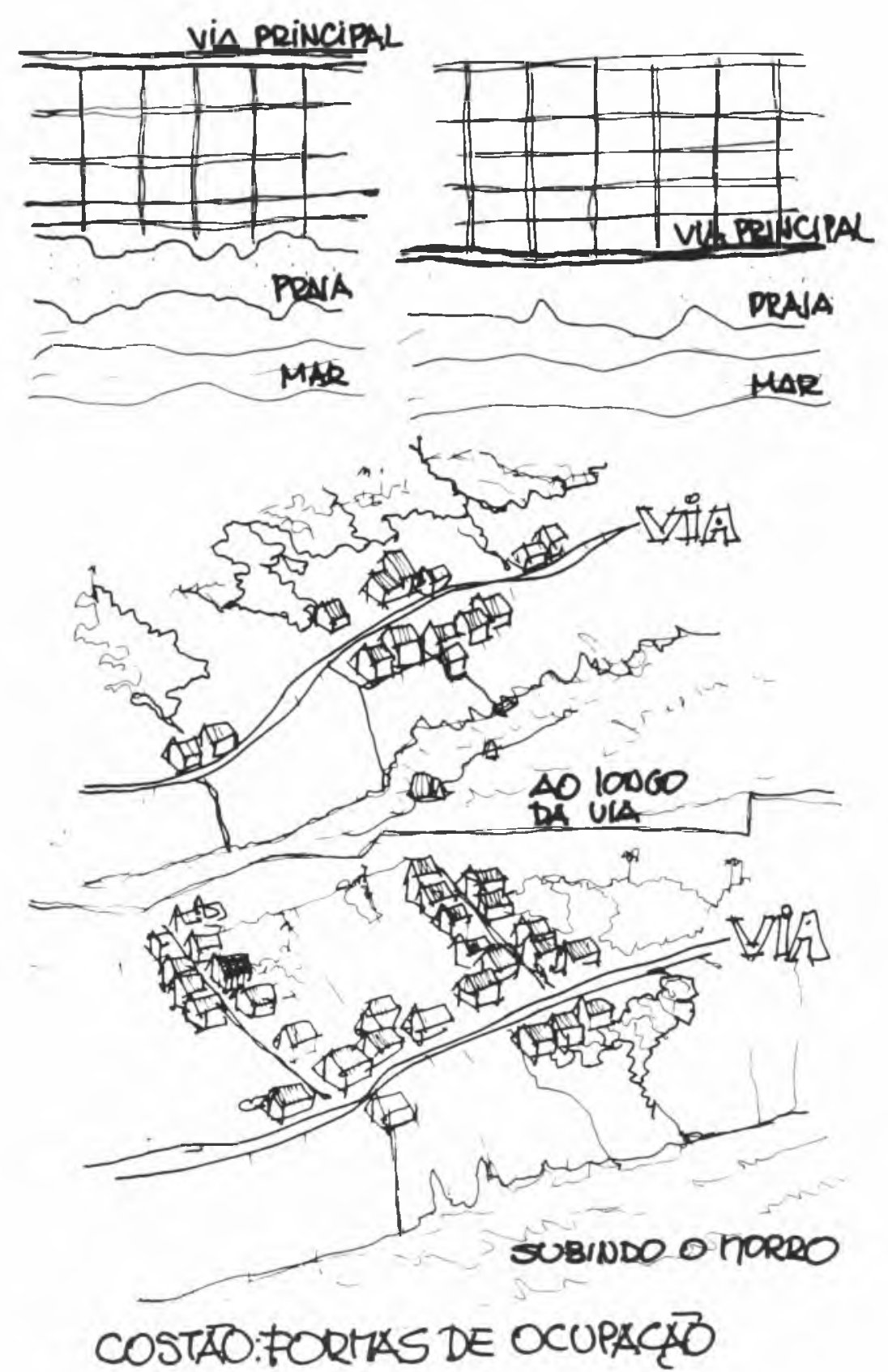


2. O seu sistema viário pode ou não estar ligado à praia. Nos loteamentos mais modernos, principalmente aqueles construídos a partir dos anos 70, muitas vezes as vias terminam antes de chegar na praia e servem somente de acesso às residências. O loteamento que possui uma via beira-mar denominaremos urbanização litorânea clássica e as demais formas, contemporâneas. Desta segunda forma, muitas variações são encontradas, sendo que algumas privilegiam a manutenção de faixas de vegetação nativa ou a criação de áreas ajardinadas comuns.

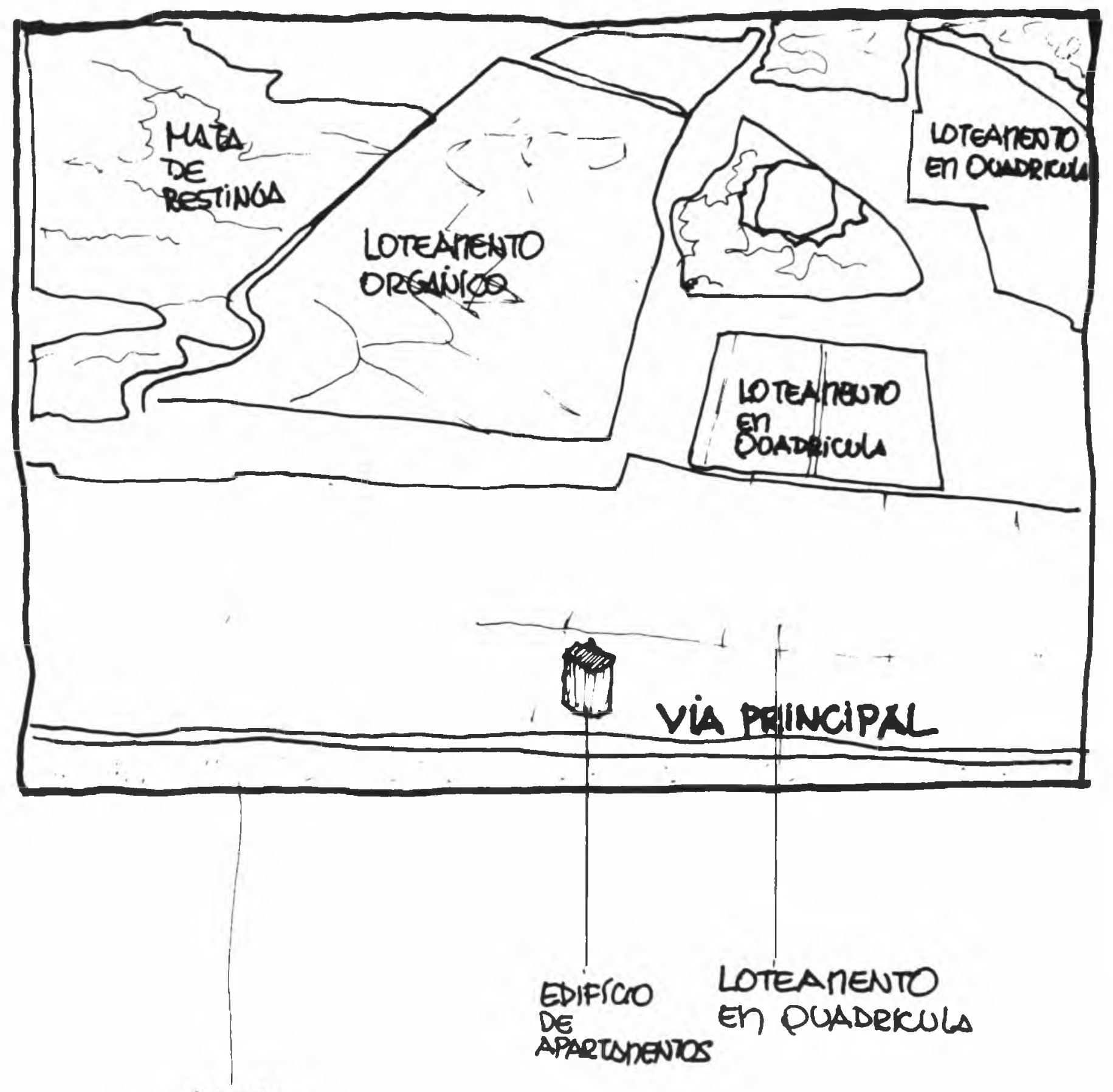

PRASA 


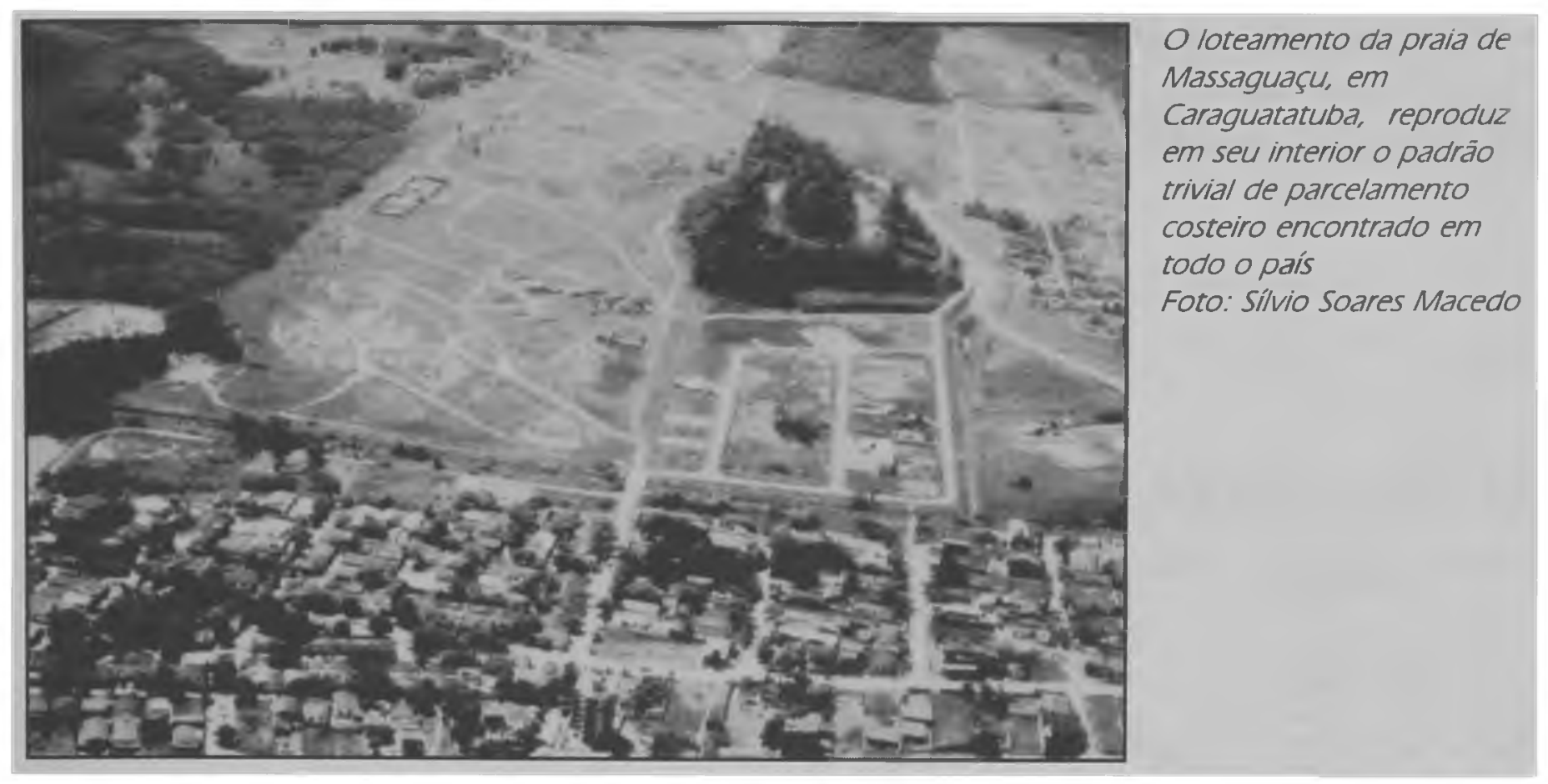

os loteatrentos sSO de preferenticis construidos E! A'REAS PLAUSS OO" EEITAS. PlaUAS

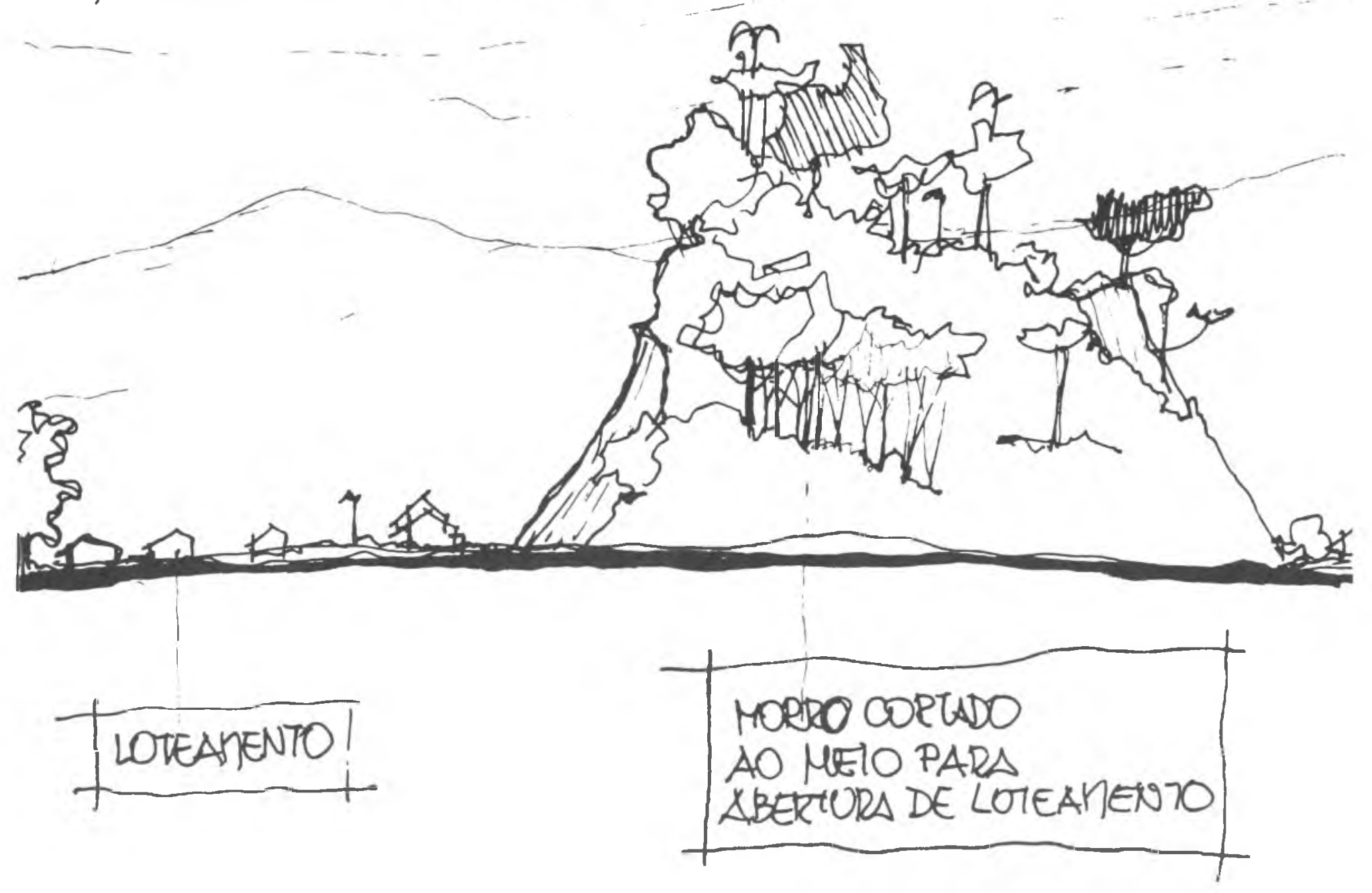


LOTEAMENTO CUSSSICO VIA PEINCPALL

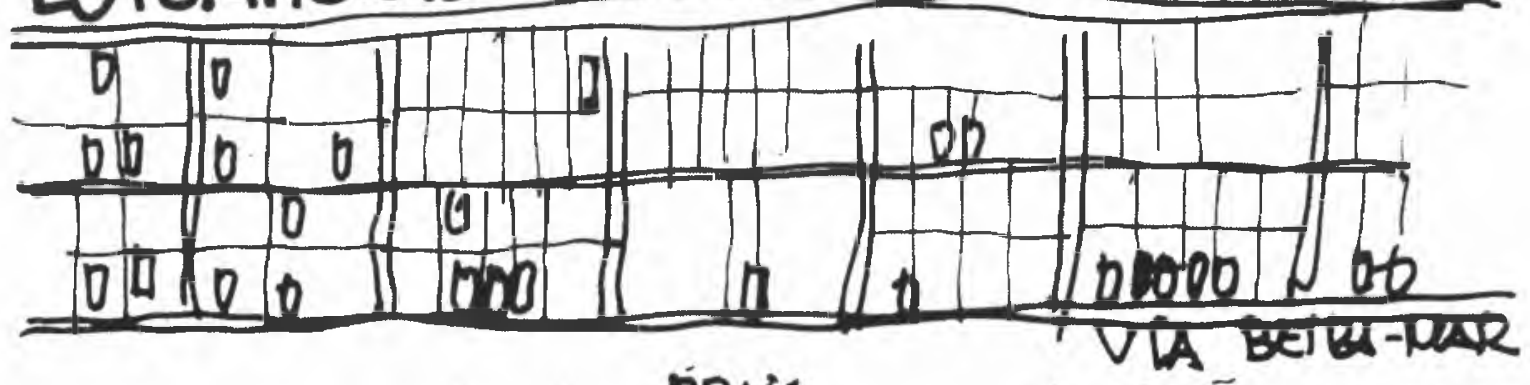

PRASA

\section{LOTEANENTO COVUENPORINED YIA PRINCIPAL}
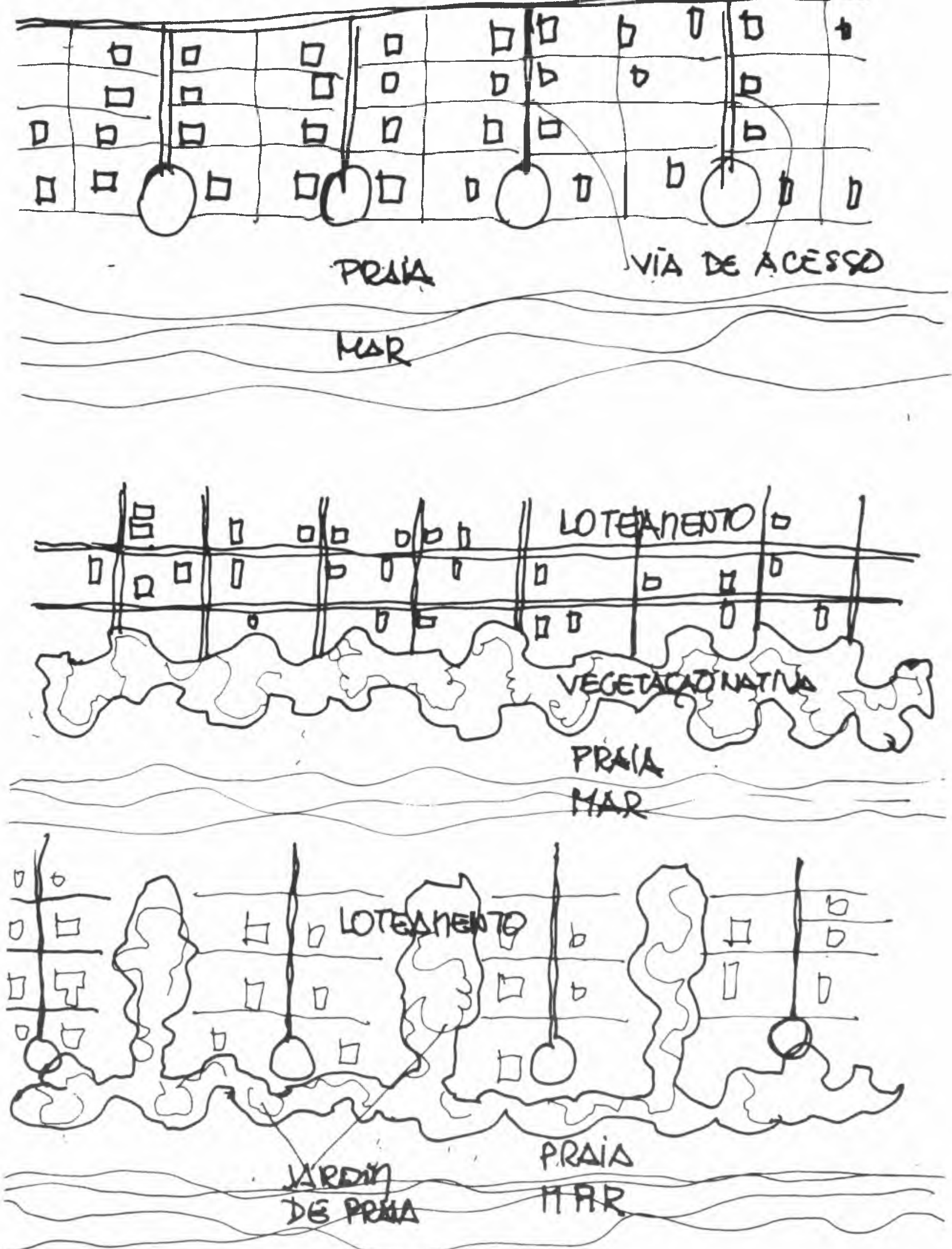
O esquema a seguir apresenta um típico loteamento contemporâneo na Praia Brava (Florianópolis), mostrando a consolidação deste tipo de estrutura em empreendimentos destinados a pessoas de elevado poder aquisitivo.
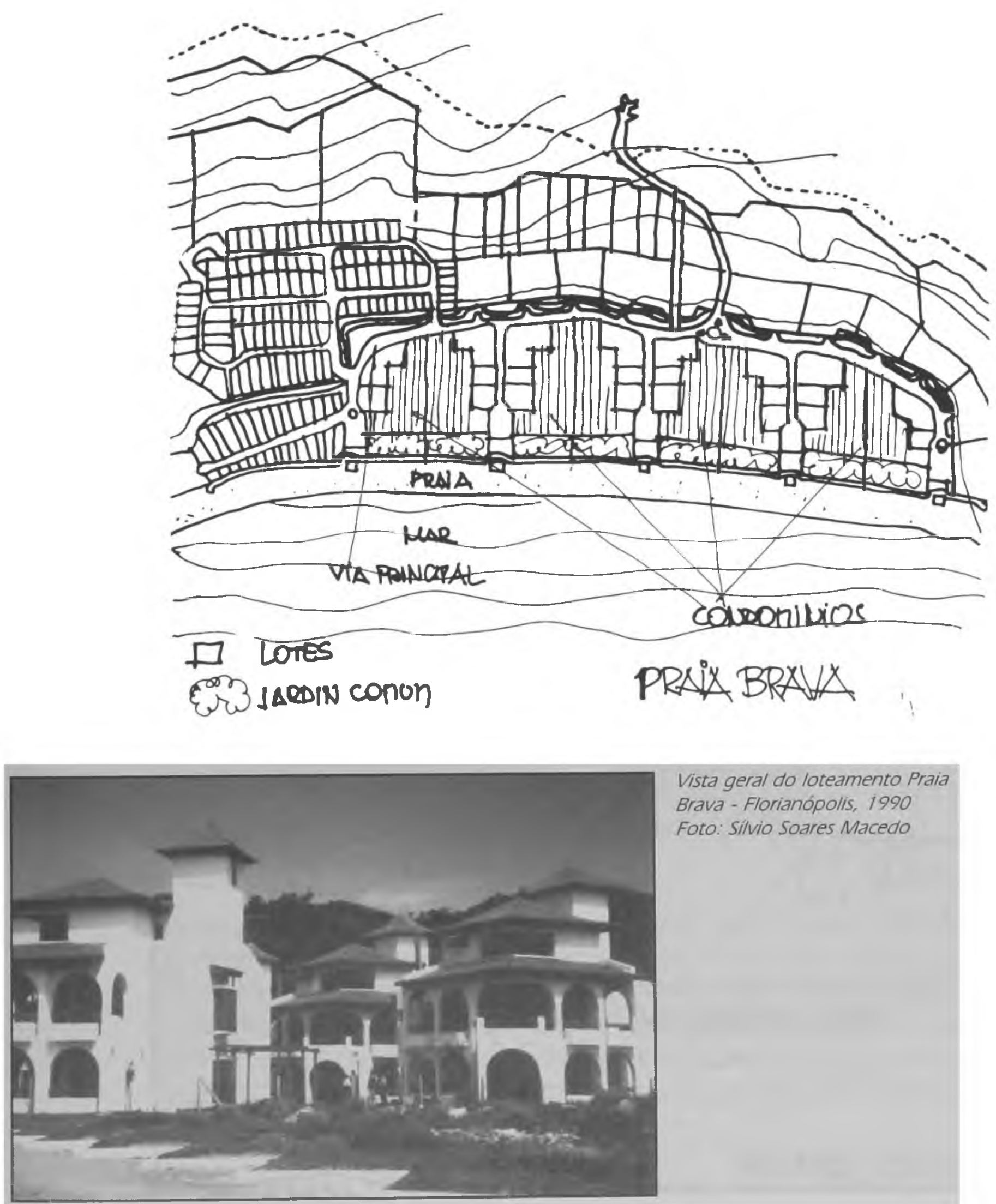

Vista geral do loteamento Praia Brava - Florianópolis, 1990

Foto: Silvio Soares Macedo 
Sílvio

Soares

Macedo

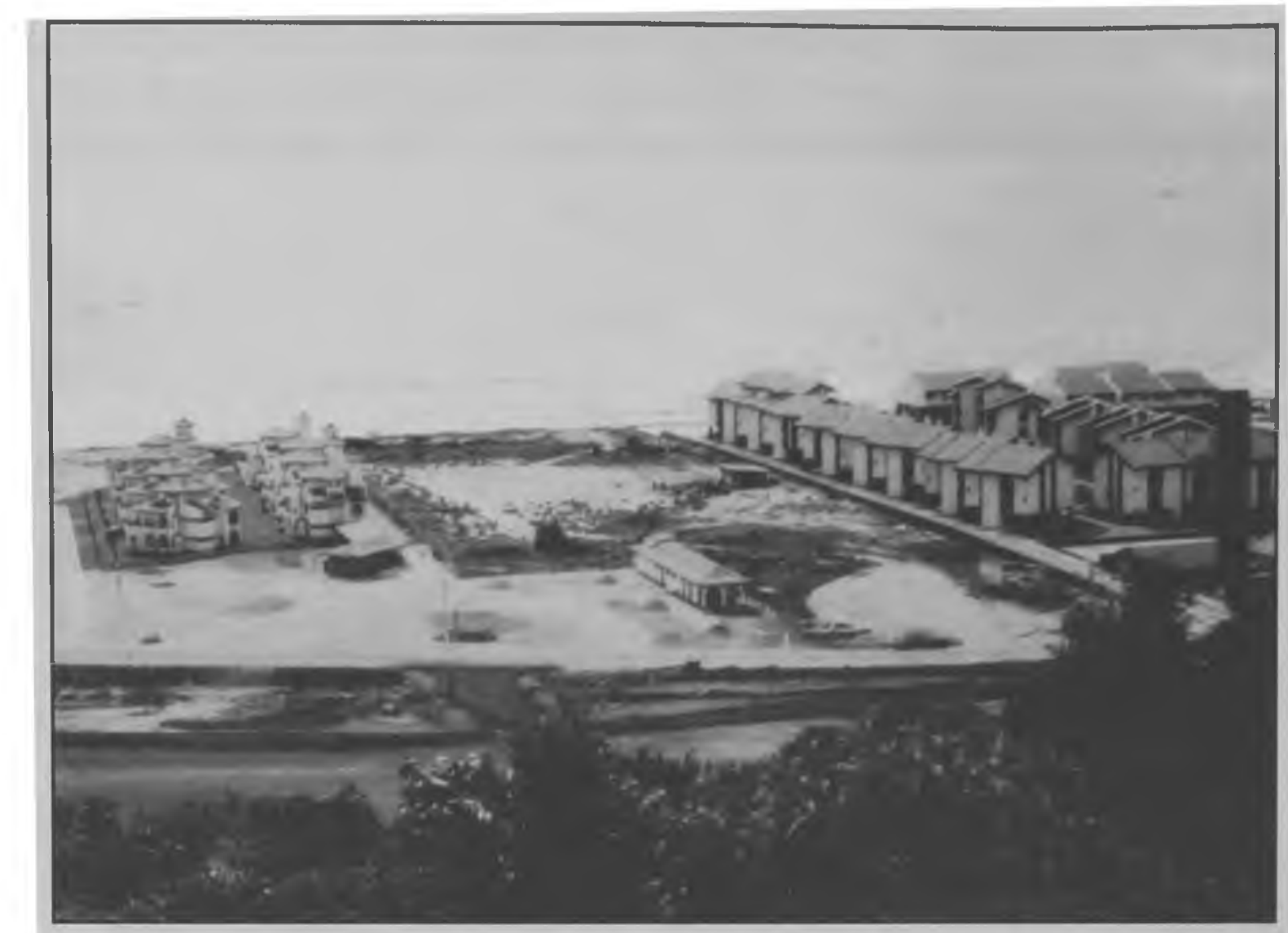

Vista geral do loteamento Praia Brava - Florianópolis, 1990 Foto: Sívio Soares Macedo

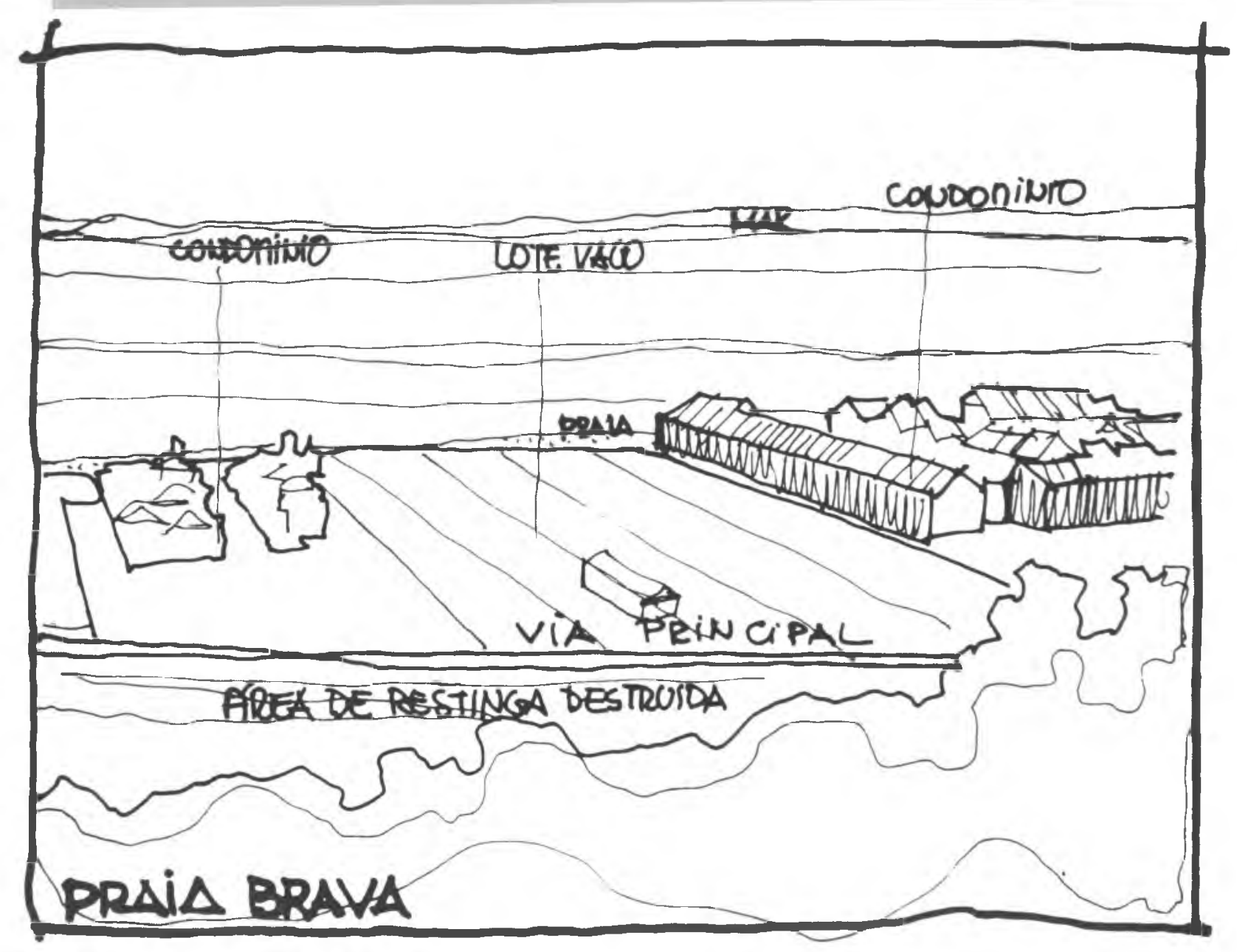


3. Podem ser encontrados, de acordo com sua estrutura morfológica, nas seguintes configurações:

3.1 Horizontal - constituem a grande maioria dos empreendimentos imobiliários existentes, compostos por habitações de não mais de dois andares. Estendem-se por grande parte dos municípios litorâneos destinados a fins exclusivamente turísticos. Aqueles inseridos em áreas urbanas de porte, como as capitais e cidades de porte médio possuidoras de uma atividade econômica diversificada, apresentam a habitação de primeira residência como forma básica de uso do solo. Nestas áreas as edificações são tradicionalmente implantadas com amplos recuos dentro de seus lotes.

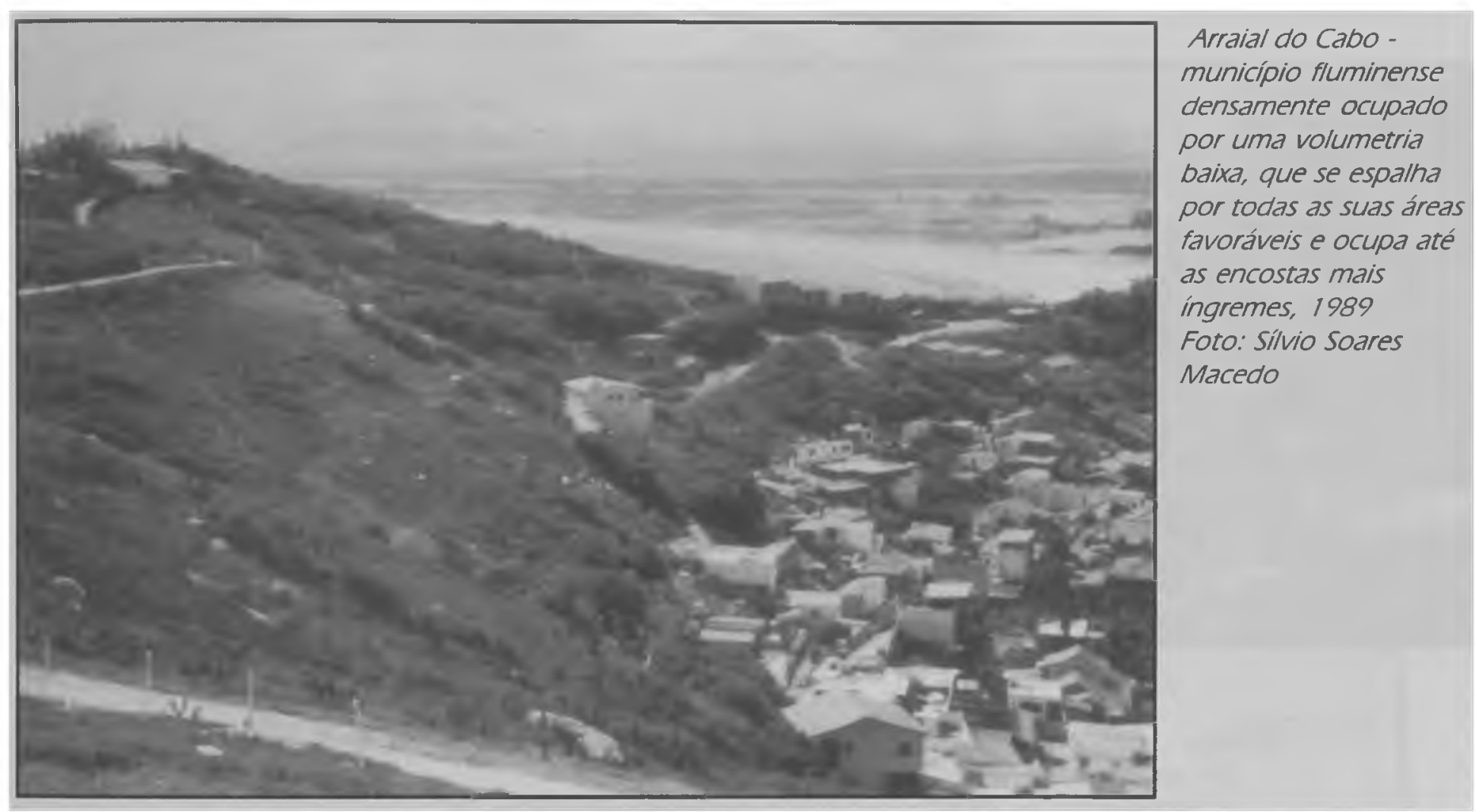

A implantação deste tipo de loteamento exige áreas planas e preferencialmente extensas. Espalham-se ao longo das praias sobre terrenos ocupados por areais, dunas e matas de restinga, que são então totalmente processados. Cria-se ao fim de alguns anos um novo cenário, uma nova paisagem, permanecendo somente a praia com configuração similar àquela existente antes da ocupação do lugar.

A expansão das frentes de atuação da indústria imobiliária é constante. O esgotamento das possibilidades de ocupação e a necessidade de 
novos empreendimentos têm provocado uma ampliação significativa das áreas já abertas e ocupadas, direcionando ainda em muitos trechos do litoral a ocupação de áreas de costão. Esta tem sido uma forma de urbanização corriqueira em diferentes trechos da costa, sendo que os melhores exemplos podem ser encontrados nas cidades do Rio de Janeiro (RJ) e Guarujá (SP), além de todo o trecho de litoral entre Santos e Angra dos Reis.

O custo mais elevado de assentamento de uma casa em local de costões é um fator que proporciona ao seu usuário, além de vistas panorâmicas, uma privacidade sem par $\mathrm{O}$ acesso às praias - quando existentes - geralmente é restrito aos donos das residências, de certa forma privatizando-as.

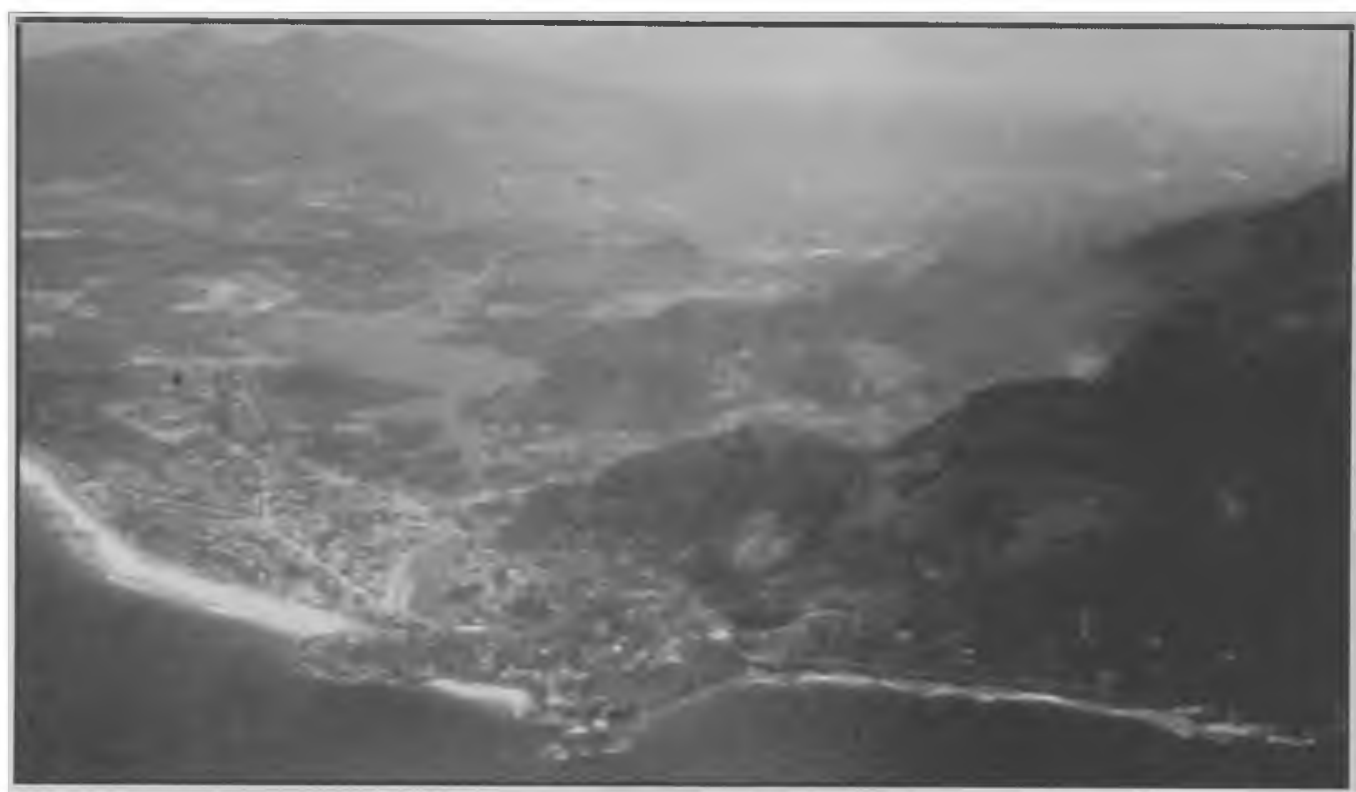

Rio de Janeiro - Vista da ocupação do costão na Barra da Tijuca, cuja área já está totalmente desmatada

Foto: Silvio Soares Macedo

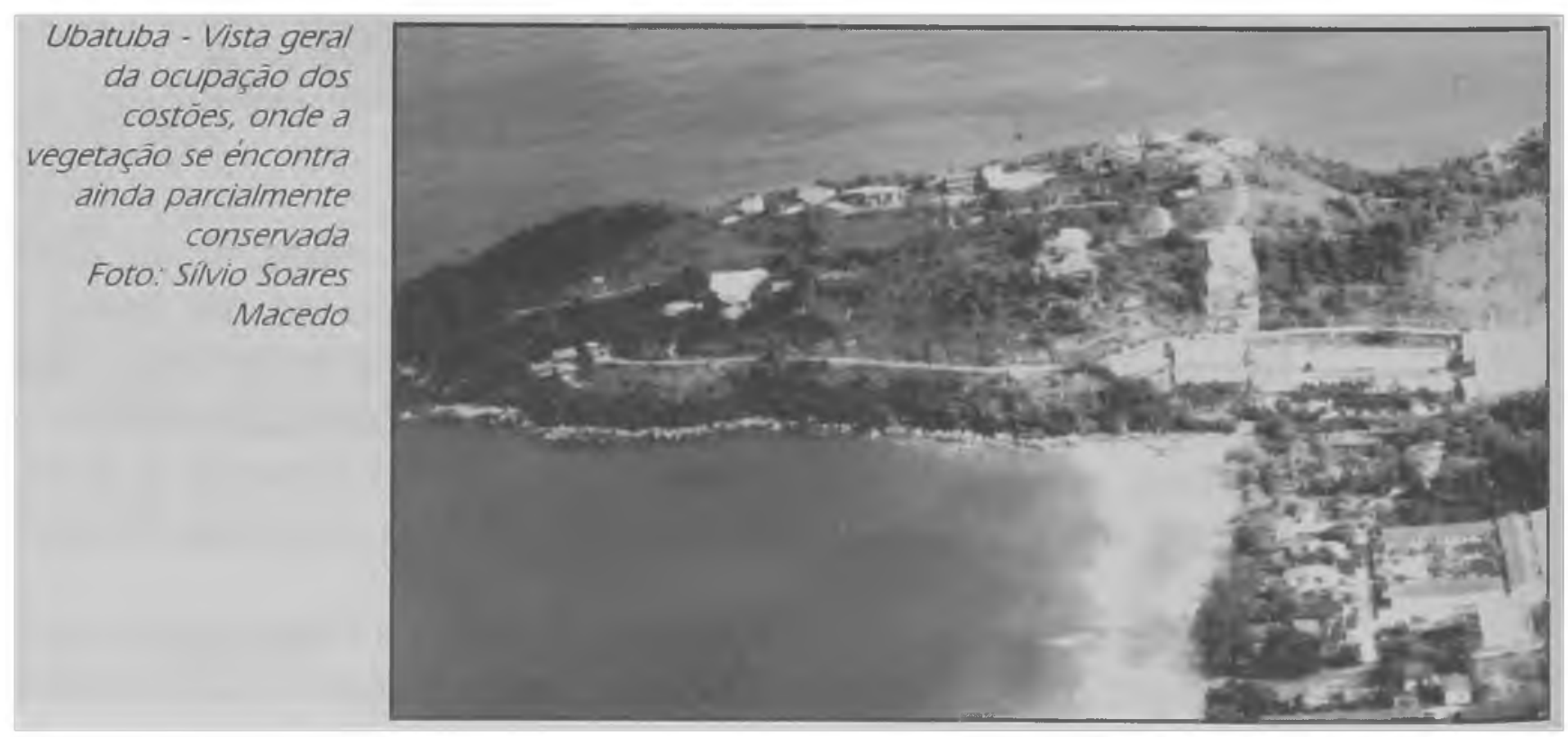


Todo loteamento horizontal apresenta as características gerais do bairro-jardim brasileiro, com edifícios isolados nos lotes, ruas arborizadas, jardins e quintais particulares, áreas públicas e semipúblicas comuns e toda a sua estrutura voltada para o aproveitamento máximo das áreas de praia. A paisagem obtida quando um destes loteamentos se consolida é praticamente a mesma, de um bairro convencional de uma cidade qualquer do interior do país.
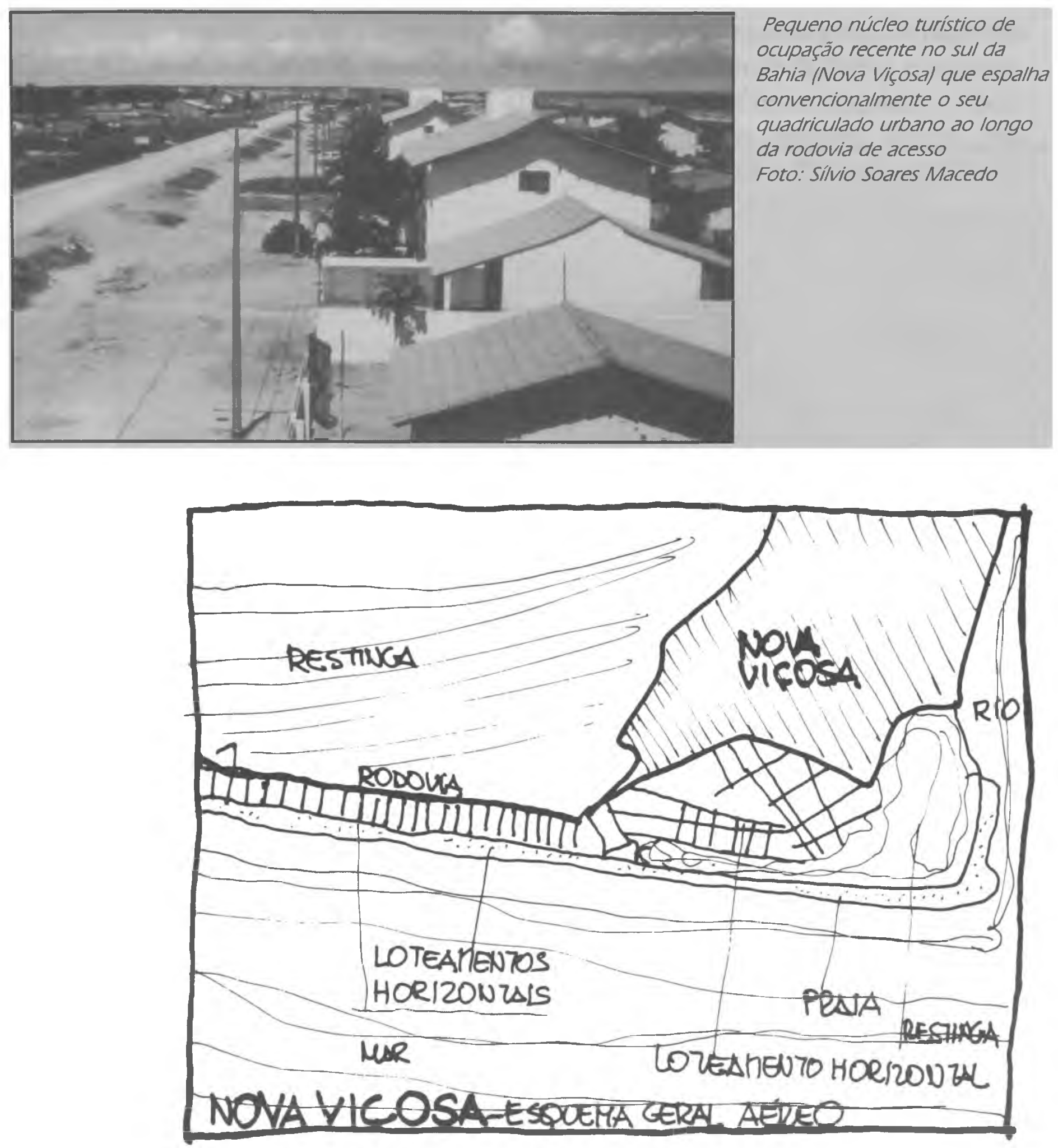
3.2. Vertical - poucos são os loteamentos previstos desde o início para assumir tal configuração. Em geral o surgimento de prédios corresponde a uma etapa posterior de ocupação de um loteamento horizontal qualquer Muitas municipalidades ainda restringem o gabarito de suas áreas litorâneas, de modo a conferir à paisagem um caráter menos urbanizado (ou pelo menos de bairro-jardim), impedindo assim a construção de edifícios de muitos andares.

Os bairros verticalizados litorâneos estão geralmente inseridos, em estruturas urbanas complexas de cidades de médio e grande portes, onde a atividade econômica é diversificada. São também encontrados em alguns grandes centros turísticos, tais como Guarapari (ES), Caraguatatuba (SP) e Camboriú (SC).

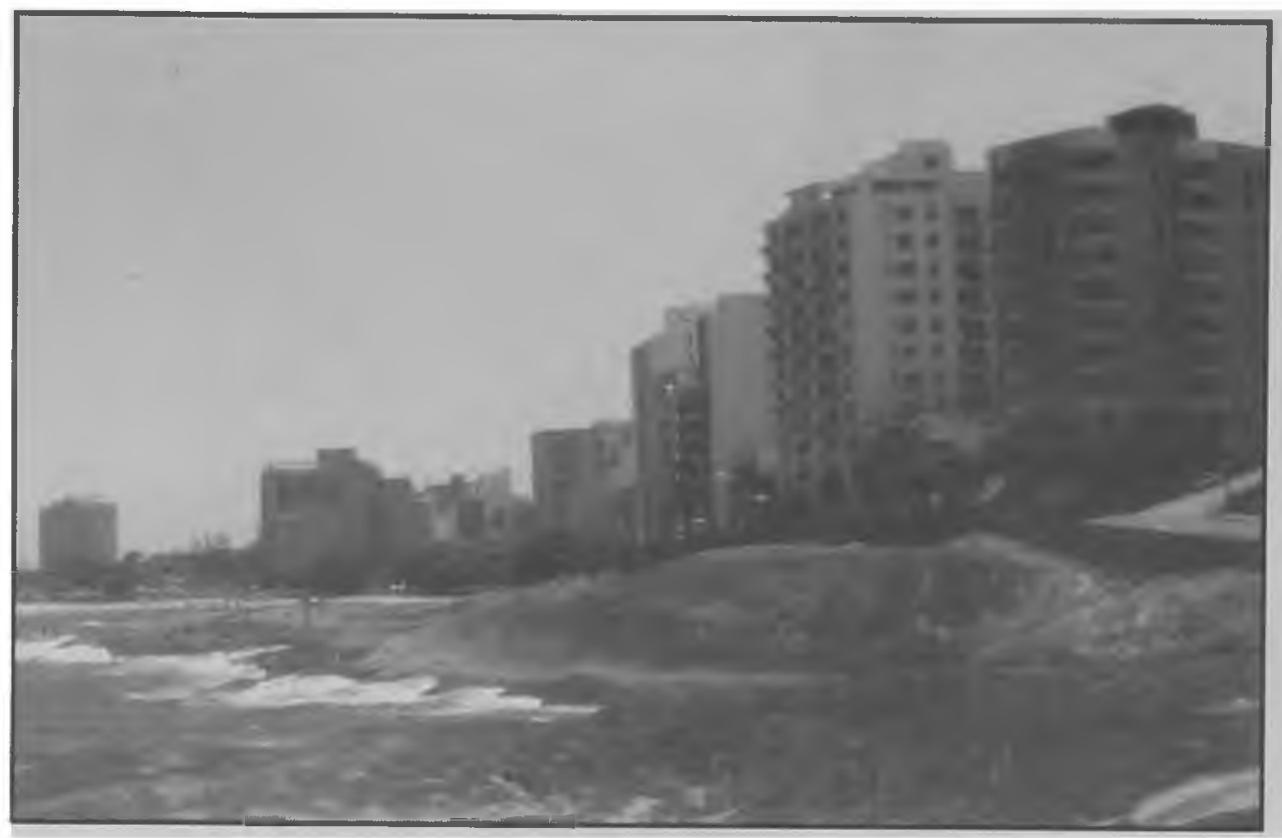

Guarapari - a intensa expansão urbana deste centro turístico nacional conduziu a uma eliminação total da cobertura vegetal original. As edificaçōes ocupam inclusive parte do costão, uma das últimas áreas costeiras a ser urbanizada Fotos: Silvio Soares Macedo

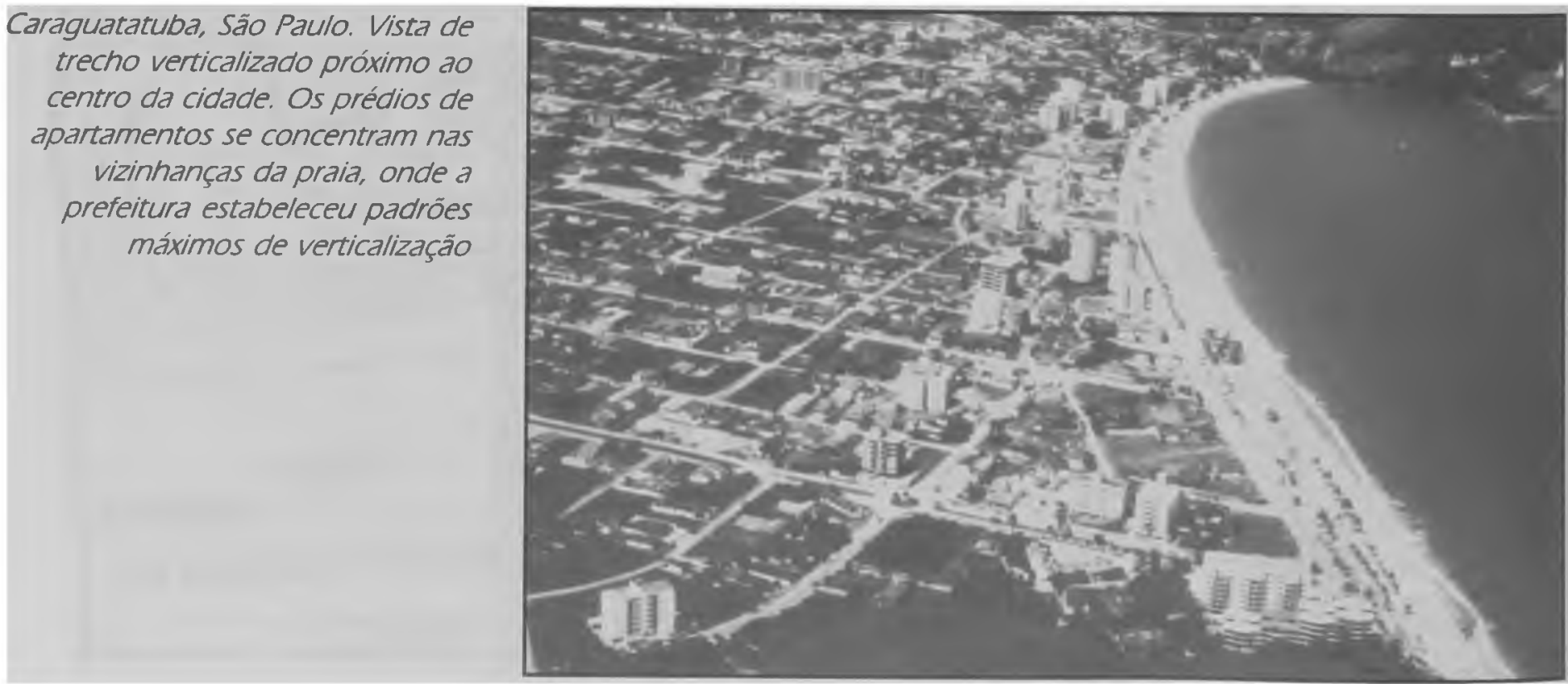


Na maioria dos pólos turísticos do litoral não se encontram estruturas verticalizadas completas, mas sim estruturas mistas, onde edifícios de apartamentos, agrupados ou isolados, são construídos em meio a um tecido horizontal convencional.

O exemplo da foto, típico de área verticalizada, mostra também o convivio destas duas formas de ocupação urbana do litoral apresentando todos os elementos de um loteamento costeiro tradicional: casas e prédios isolados, avenida beira-mar, desmatamento total da área loteada, recortes de morros...

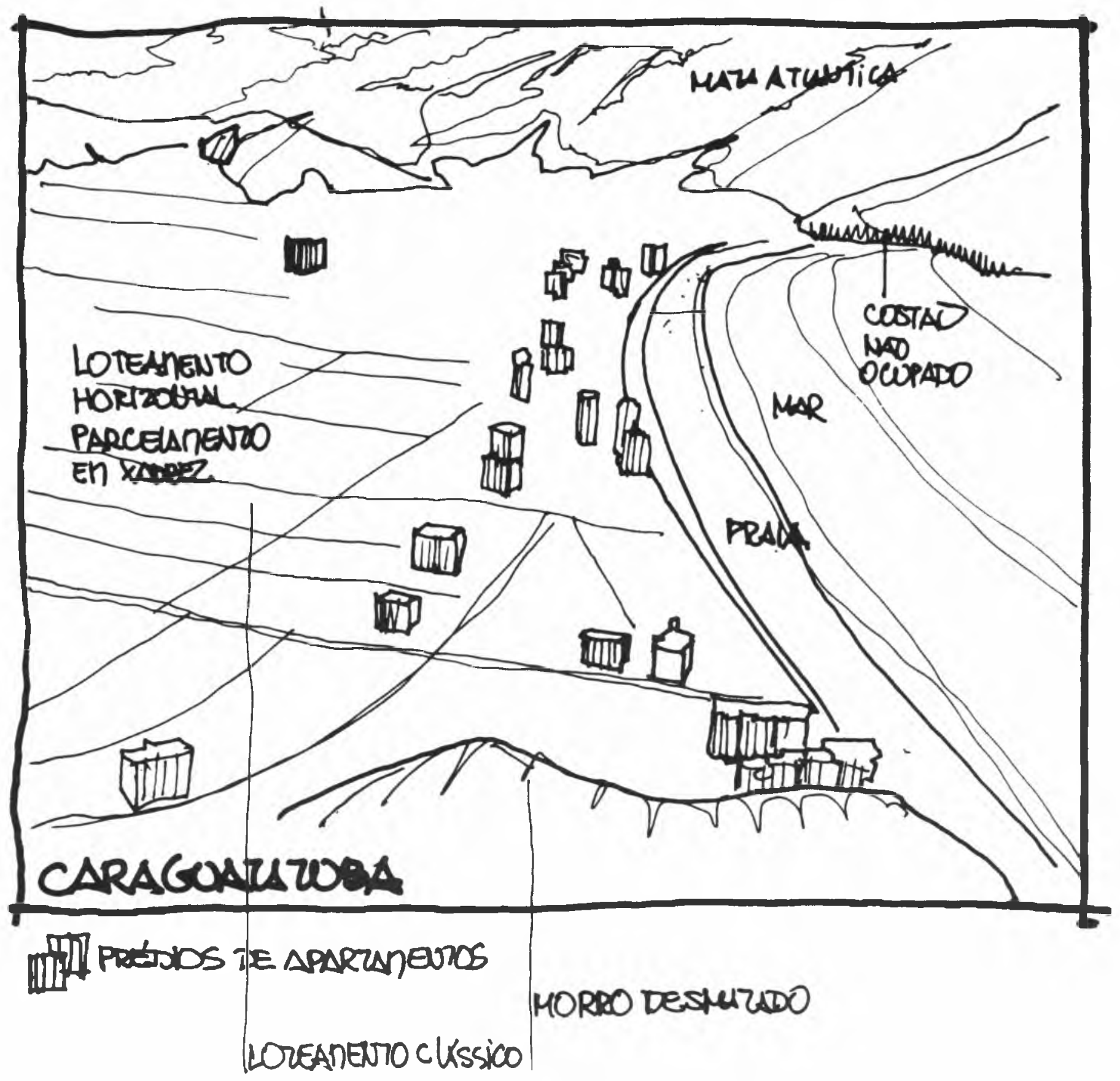


Ambas possuem utilizações diferentes. Aquelas que estão inseridas em cidades de porte, como Rio de Janeiro, Santos ou Vitória, e que são constituídas em bairros convencionais, têm seus espaços constantemente utilizados. As que estão localizadas em áreas exclusivamente turísticas apresentam uma ocupação restrita às temporadas de verão e são usadas primordialmente por moradores das cidades vizinhas, - caso das áreas de veraneio nas proximidades de Natal, Aracajú ou Florianópolis.

A forma de ocupação está ligada à distância e à acessibilidade em relação aos grandes centros populacionais. Núcleos turísticos como Praia Grande (SP) e o conjunto de praias de Angra dos Reis, possuem uma intensa utilização, que se estende por todo o ano. No extremo oposto, Itaúnas (ES) e Rio do Fogo (RN) são pequenos núcleos distantes de qualquer grande aglomeração urbana e têm uma pequena utilização.

Pode-se agregar a estas duas formas de ocupação do litoral uma terceira, ainda incipiente no país: a constituição de centros de recreação isolados, geralmente centrados em volta de um clube, hotel, ou mesmo de um condomínio, que se instalam em uma região pouco povoada e que representam a médio e longo prazos em pontos de atração para outros investimentos turísticos. Um exemplo é o Hotel Transamérica em Comandatuba, cujo complexo turístico foi edificado na ilha de mesmo nome, próximo ao município de llhéus, no estado da Bahia ${ }^{18 .}$

Morfologicamente estas situaçōes urbanas procuram trabalhar com os elementos existentes com baixos índices de processamento, mantendo a princípio intactas parcelas consideráveis da paisagem nativa, que é utilizada por seus empreendedores como chamariz de turistas - tanto compradores como visitantes.

(18) Hubert Macé classifica as estruturas urbanas habitacionais litorâneas em três tipos:

1. Ocupação extensiva e desordenada - correspondente aos trechos horizontais.

2. Muralhas litorâneas - denominadas Manhattan balnearias lequivalentes aos nossos trechos verticalizados, às quais relaciona Miami Beach como modelol.

3. Ocupação modular - núcleos isolados lque aponta como destinados a camadas de maior poder aquisitivol.

In: CAZES, G.; LANOUAR, R. e RAYONARD, Y. L'aménagement touristique. p. 56 e 57.

\begin{tabular}{|l|l|}
\hline 170 & Palsagem \\
Ambiente \\
Ensaios \\
11
\end{tabular}

São Paulo n. 11 p. 131202 dez. 1998 


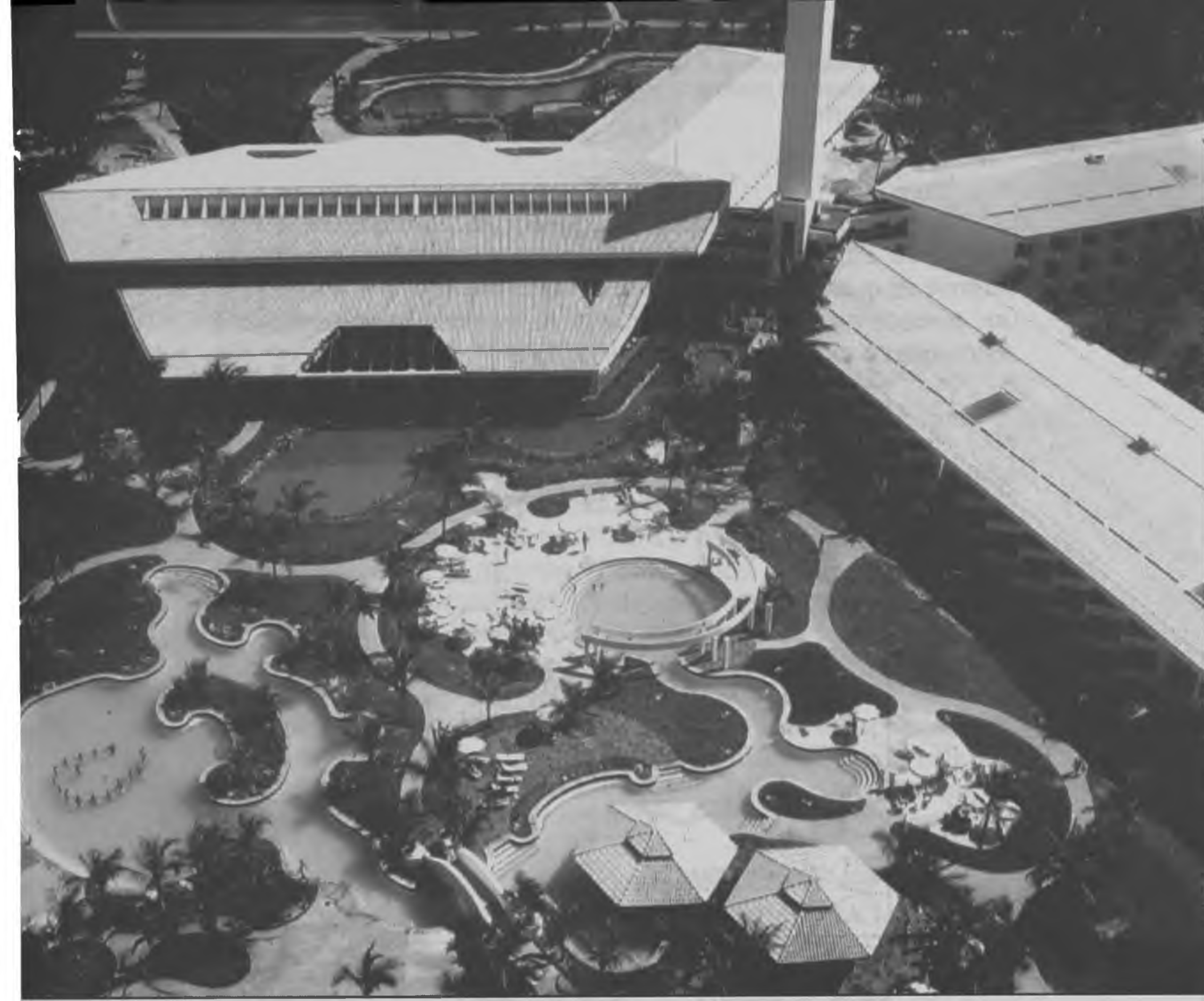

Hotel Transamérica, Bahia - situado em meio a extensos coqueirais, oferece como atrativos básicos o mar e a paisagem natural pouco processada.

Cartão Postal: Coleção Juliana Sztraijtmann

Dentro desta categoria pode ser arrolada uma série de empreendimentos imobiliários pioneiros que, à medida que são inseridos em malhas urbanas, tomam a forma de tecidos horizontais ou verticais convencionais. Geralmente são implantados dentro (ou em periferias) de área de proteção ambiental e são objeto de uma discussão da sociedade sobre a conveniência de seu assentamento.

Este é o caso do empreendimento "A península" no município de Peruíbe, próximo aos limites da estação ecológica Juréia - Itatins no estado de São Paulo. O condomínio foi alvo de moção popular contra sua construção, visto que ocuparia uma área de costão considerada ecologicamente frágil.

São Paulo n. 11 p. 131202 dez. 1998

Palsagem
Ambiente
Ensalos
11


O pequeno conjunto turístico, por si só não constitui um perigo imediato à estação ecológica, pois apresenta todas as normas de controle de qualidade ambiental desejáveis, mas a sua presença abriria um precedente à futura construção de outros, favorecendo um adensamento urbano não desejável no local ${ }^{19}$
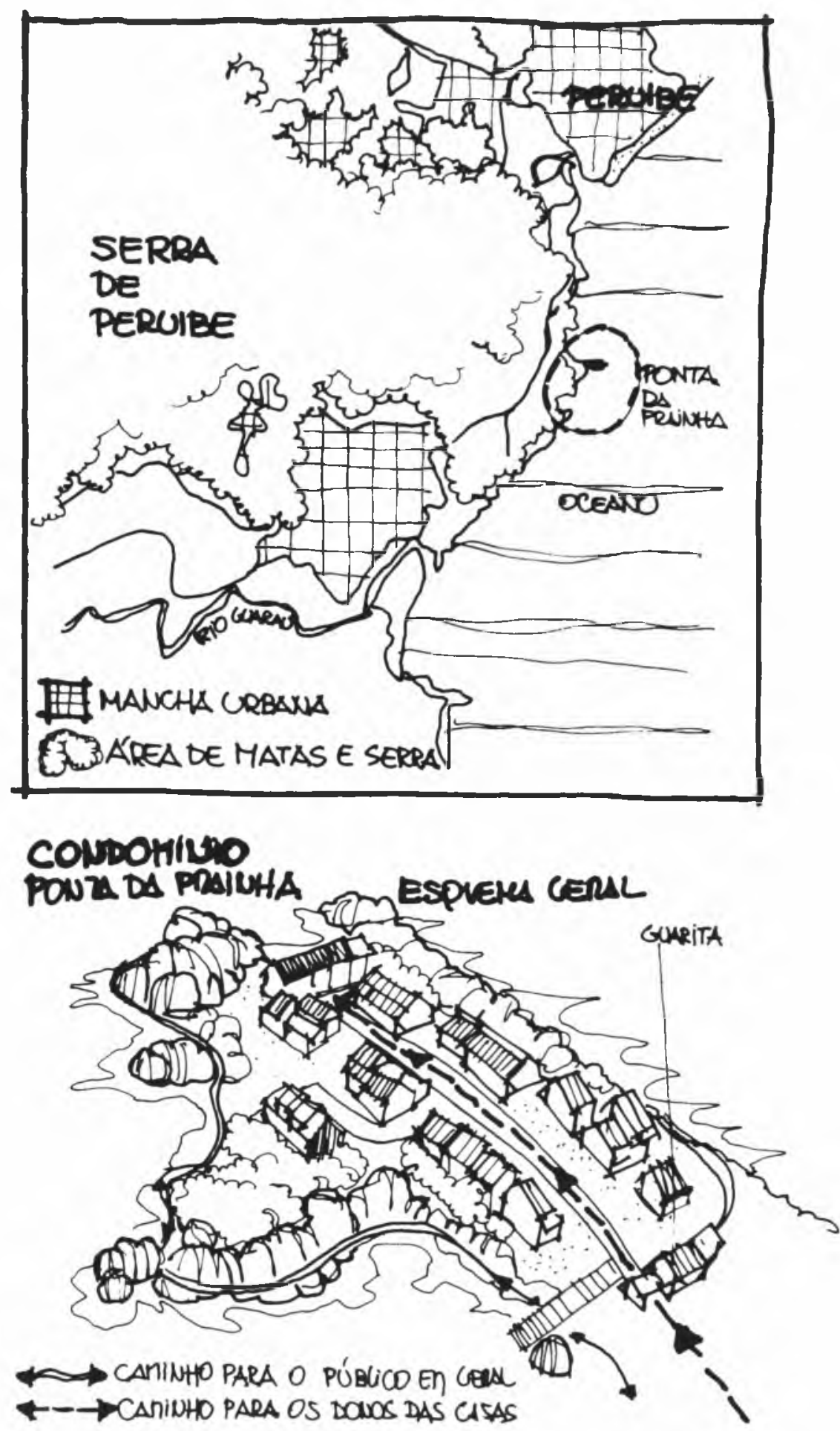

(19) O caso em questão foi objeto de estudo por solicitaçāo do Ministério Público de uma subcomissāo da CEPA - Comissão de Estudos Ambientais da Universidade de São Paulo no ano de 1988, que concluiu a não conveniência da instalação de tal empreendimento, devido justamente ao fato de se abrir um precedente de ocupação em área tāo frágil.

Vide CEPA Comissāo de Estudos Ambientais. Relatório Ponta da Prainha. 


\section{5}

ormas de utilização e estruturação morfológica

O uso da praia apresenta-se no século 20 com as características e a morfologia de um grande parque local linear, onde a população busca um lazer alternativo às suas atividades do cotidiano urbano 20 . Esta idéia se configura, a princípio, como uma imagem antagônica àquela normalmente atribuída a um parque, que é tradicionalmente definida por arvoredos, relvados e lagos. Porém, a praia abriga em suas águas, areias e vegetação as mesmas funçōes sociais de lazer do parque _ jogos, repouso, caminhadas, contemplação e encontros, reconstituindo o parque urbano moderno e propiciando ainda de modo especial, o contato direto e constante ao usuário com a água 21

O início deste processo está associado ao surgimento dos primeiros loteamentos urbanos à beira-mar (como Copacabana e outros mais, no início do séculol consolidando-se desde então como padrão para as cidades litorâneas brasileiras.

O "espaço praia" consiste em um local onde se desenvolvem as formas de lazer urbano, tanto ativo - como jogos, pesca, natação, remo, como passivo - contemplação do mar e da paisagem. Torna-se então palco de uma série de situaçōes de relacionamento social, como o namoro, a conversa, a troca de informaçōes, o comer em grupo em bares e restaurantes.

Esta apropriação social exige uma estruturação espacial diferente para cada situação, variando de organizaçōes muito simples, rústicas, até outras altamente elaboradas, como as encontradas nos calçadões à beira-mar das grandes cidades.

Os esquemas gráficos, a seguir, indicam algumas das tipologias mais comuns da costa brasileira, com diferentes graus de processamento.

(20) Vide MACEDO. Silvio Soares. Os espaços livres de edificação e o desenho da paisagem urbana em Anais do II SEDUR, p. 106.

(21) Miranda Magnoli coloca as diversas etapas de uso e apropriação do espaço urbano-parque. caracterizando como atividades de importância para estes espaços no século 20, as atividades de lazer ativo com a criação maciça de quadras e outras áreas apropriadas para esportes. No caso a referência é - parque americano, mas é apontada e claramente perceptível em todos os projetos de parques contemporâneos no Brasil a influência dessas linhas conceituais.

Vide MAGNOLI, Miranda M. E. M. O parque no desenho urbano. In: Anais do II SEDUR, p. 111 a 120.

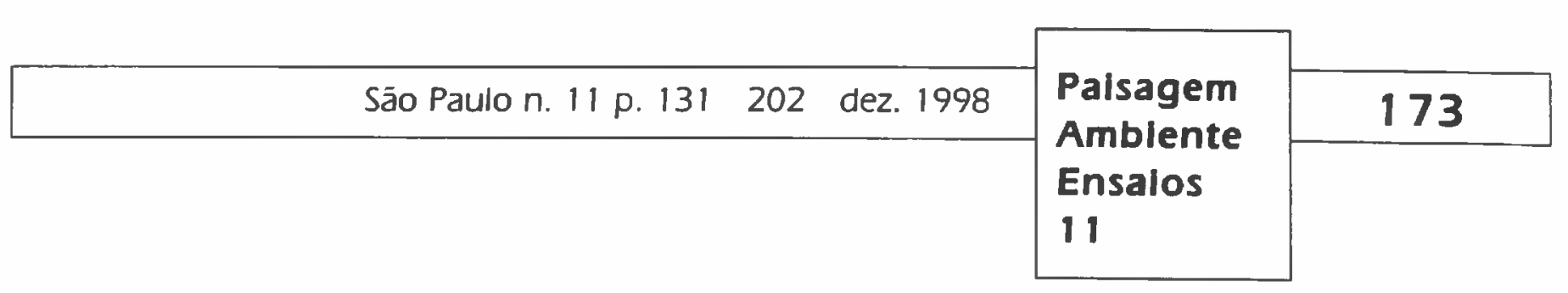




\section{Rústico}

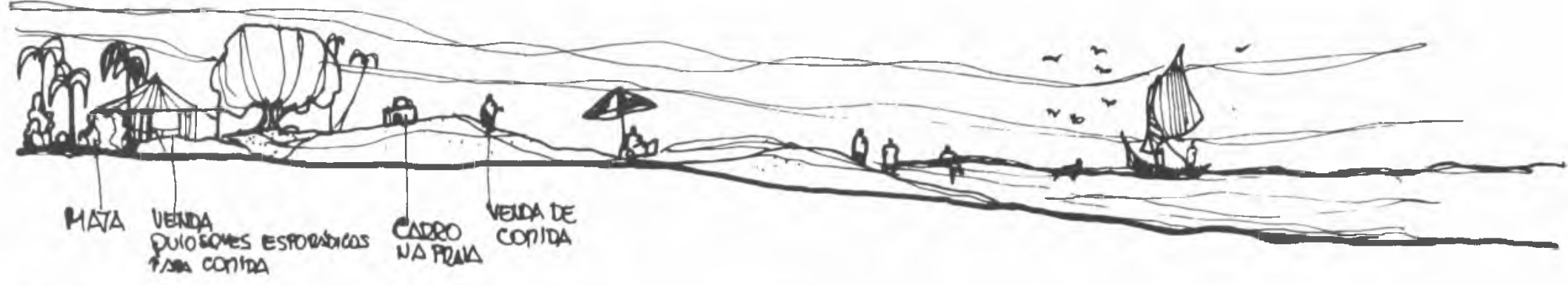

2. RúsTico

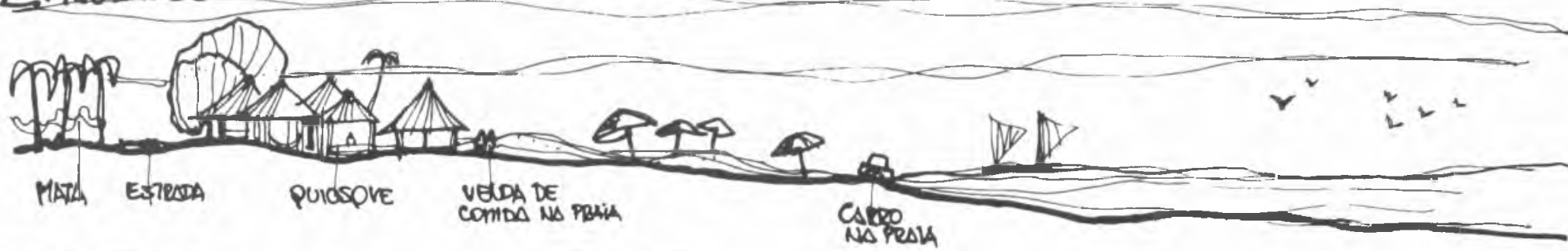

3. (1)

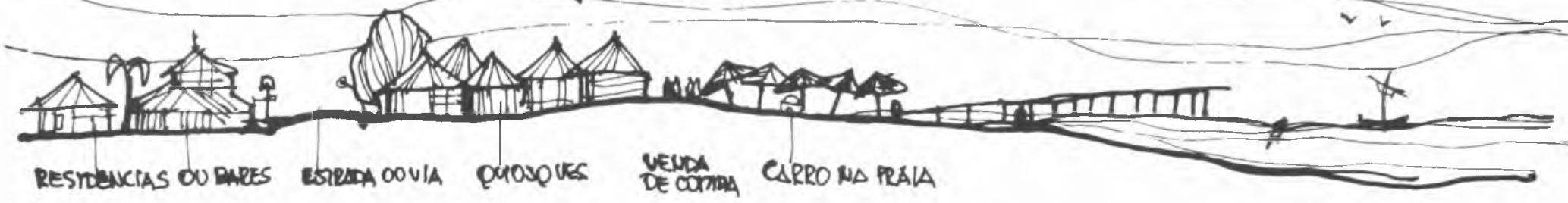

4. ORANO

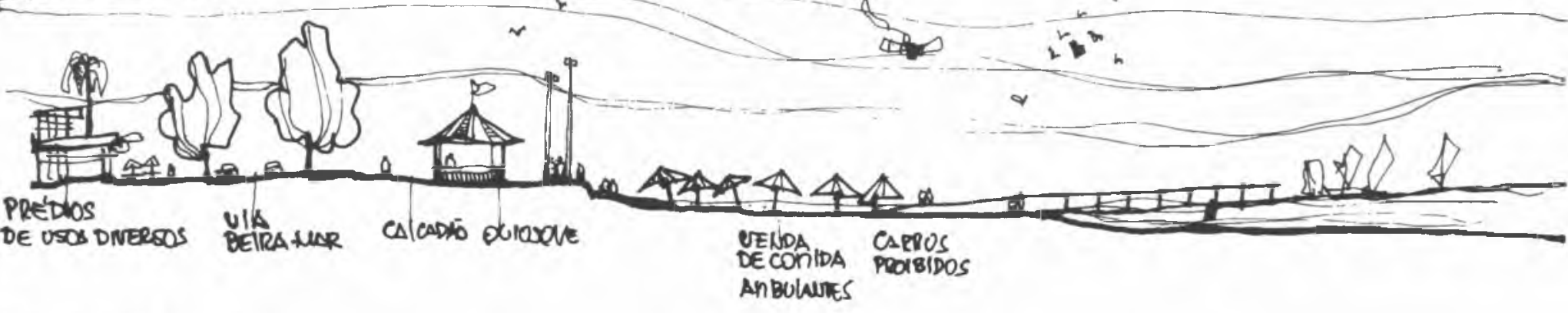

\section{Oreano}

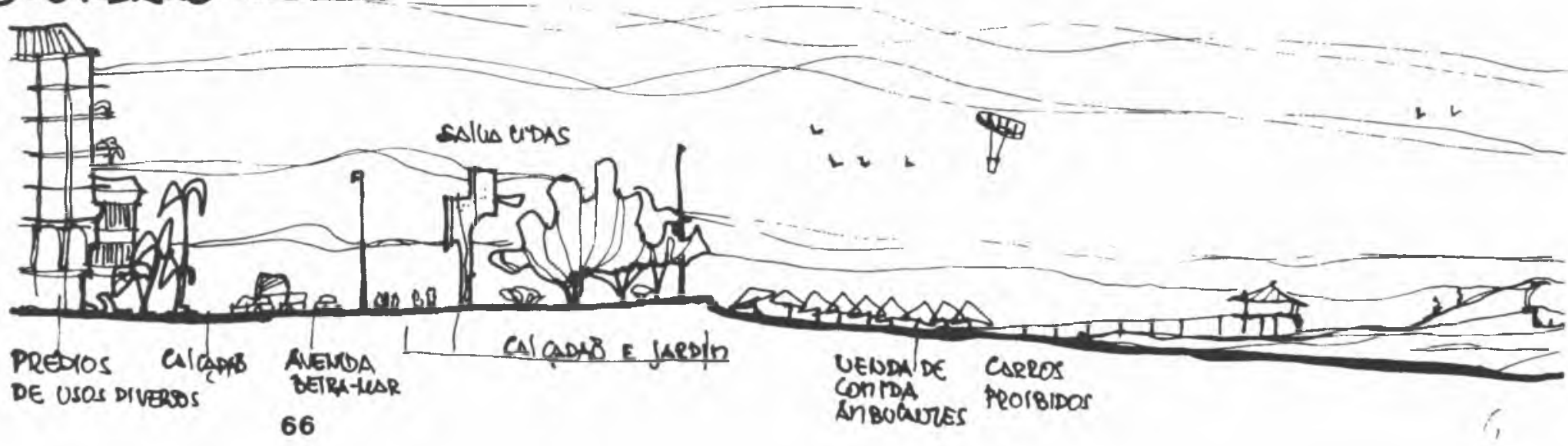


Estas representações mostram que, a partir de um núcleo básico, podese equipar um local para receber um número maior de usuários e oferecer-Ihes mais e melhores serviços apesar de ter como objetivo o banho de mar22. o visitante pede também a existência de bares, restaurantes e outros estabelecimentos de apoio.

A partir destas fórmulas espaciais, inúmeras outras foram construídas e são comuns em toda a costa. As mais significativas e questionáveis são aquelas que, de um modo ou de outro, prejudicam ou inibem o acesso à praia aos veranistas não proprietários de terrenos ou residências no local. Para tanto são utilizados desde artifícios de projeto, como barreiras de acesso de veículos à praia e a ausência de vias beira-mar, até a proibição municipal de excursões e piqueniques.

A eliminação da via beira-mar é um grande paradoxo, pois é uma posição urbana saudável que acaba com o movimento excessivo de veículos, mas por outro lado facilita o fechamento e a privatização de muitas praias.

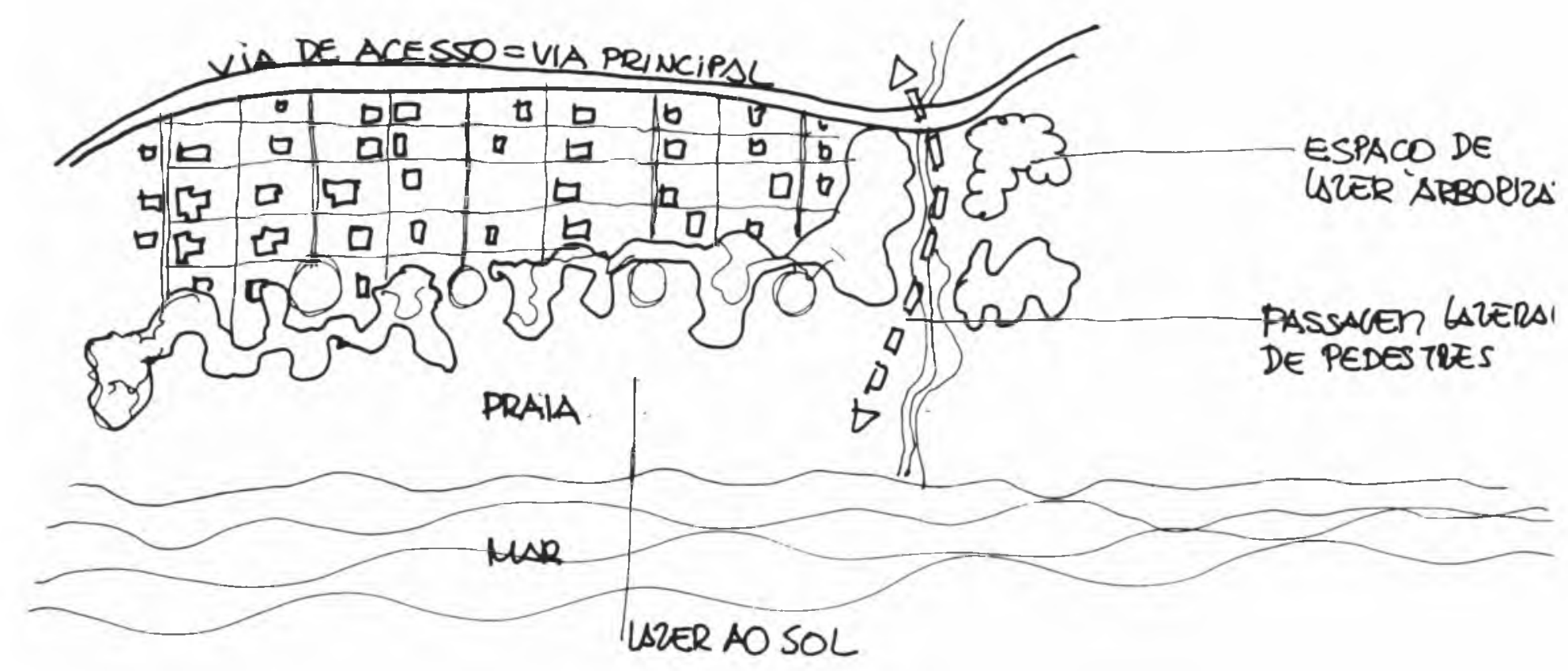

(22) O contato com o mar se transforma em ideário para o lazer e para as férias da população moderna. Jost Krippendorf, em uma pesquisa de 1985 sobre as atividades preferidas para as férias, obteve $65 \%$ de resposta que indicavam o banho de mar.

In: KRIPPENDORF. J. Sociologia do turismo. p. 64.

No Brasil é tradicional a temporada de banhos de mar no verāo e várias publicaçōes, jornais e revistas dedicam amplo espaço para a divulgaçāo dos valores turísticos das praias do país.

Vide Praias, edição especial da Revista Ouatro Rodas, anos 1988, 1989, 1990, 1991 e 1992. 

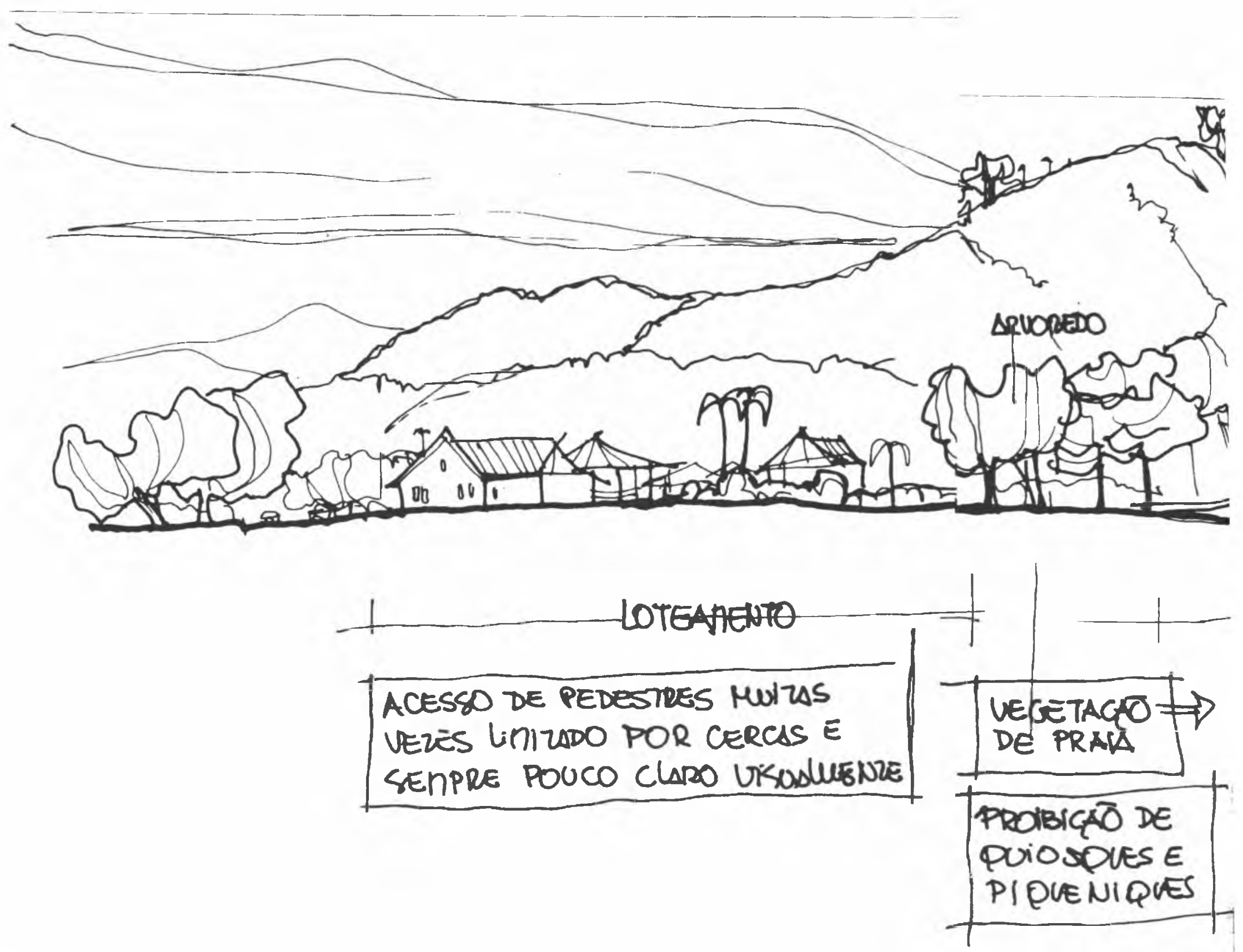


\section{$\mathbf{V}$} alores paisagísticos e a imagem associada

A estrutura morfológica de maior valor paisagístico de toda a zona costeira é o mar, cujos atributos qualificam uma praia e identificam a sua preferência por um determinado grupo social23

O mar contém praticamente todas as características para ser identificado como valor paisagístico:

Excepcionalidade - pois é uma estrutura paisagística incomum para grande parte da população que reside nas terras interiores;

Estética - no século 20 o mar é identificado culturalmente pelo seu alto valor cênico;

Afetividade - admirado e respeitado pelas comunidades que residem nas suas vizinhanças;

Simbolismo - assume para diversas populações um valor até mesmo mítico para muitos grupos sociais.

Cada trecho da zona costeira apresenta diferentes possibilidades de apropriação, sendo estas tanto mais amplas quanto respondam à trilogia qualitativa - isto é, sejam ambiental, funcional ou esteticamente assimiláveis pela comunidade.

Para o lazer, as praias de mar bravio com a rebentação próxima à areia, são mais adequadas aos esportes individuais como o surfe, e a presença de banhistas fica limitada à beira d'água. Em praias de mar tranqüilo as possibilidades de usufruto da água são maiores para todos e a natação, o remo e demais esportes náuticos podem ser livremente praticados.

Para a produção e pesca, as áreas de estuário apresentam condiçōes excepcionais de trabalho. Entretanto, não são sempre adequadas para

(23) No desenvolvimento da pesquisa "Paisagem, Urbanização e Litoral" que serviu de base para este trabalho, verificamos os indicadores turísticos das diversas praias do país, em especial daquelas situadas nas áreas de estudo. Para tanto consultamos os guias de praia Quatro Rodas, folhetos turísticos e cadernos de turismo do Jornal Folha de S. Paulo. 
as diferentes modalidades de lazer, pois por muitas vezes suas praias são parcas e lodosas e os turistas normalmente preferem praias mais limpas e de águas claras, mesmo que mais distantes ou de difícil acesso.

Temperatura - presença de recifes de coral e arenito e exposição ao vento são outros fatores que condicionam a qualificação das áreas litorâneas ao uso, inibindo ou atraindo a presença das grandes massas turísticas.

Temperatura - dependendo da temperatura do ambiente e da água as praias terão uso restrito a alguns meses do ano (Sul/Sudeste) ou uso intermitente (Nordeste)

Recifes de coral e de arenito - possibilita a existência de inúmeras praias de mar calmo (como por exemplo as dos estados de Pernambuco e Alagoas), propícias aos banhos de mar. Quando expostas (total ou parcialmente) são locais ideais para o passeio e a pesca, além de contribuir morfologicamente para a constituição da paisagem.

Além do mar, as áreas de maior valor paisagístico são aquelas ocupadas pelas praias, onde a população permanece durante a maior parte da sua estadia e nas quais as atividades sociais se desenvolvem plenamente 24

Em termos qualitativos, as praias destacam-se pela presença de inúmeras possibilidades de uso para as massas de veranistas, independente da estação do ano (o que não ocorre com o mar).

Morfologicamente identificam-se dois tipos de formação de praias:

Praias lineares - as denominadas praias grandes, que se estendem por quilômetros e que, a não ser por edificações e vilas, não apresentam nenhuma estrutura morfológica significativa que possibilite a sua imediata identificação pela população.

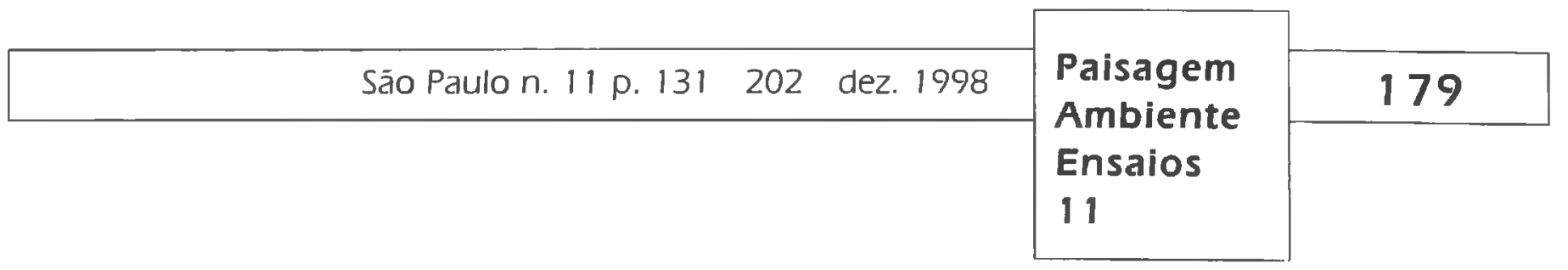


Sílvio

Soares

Macedo
Paisagem, Modelos Urbanísticos e as Áreas Habitacionais de Primeira

e Segunda Residência
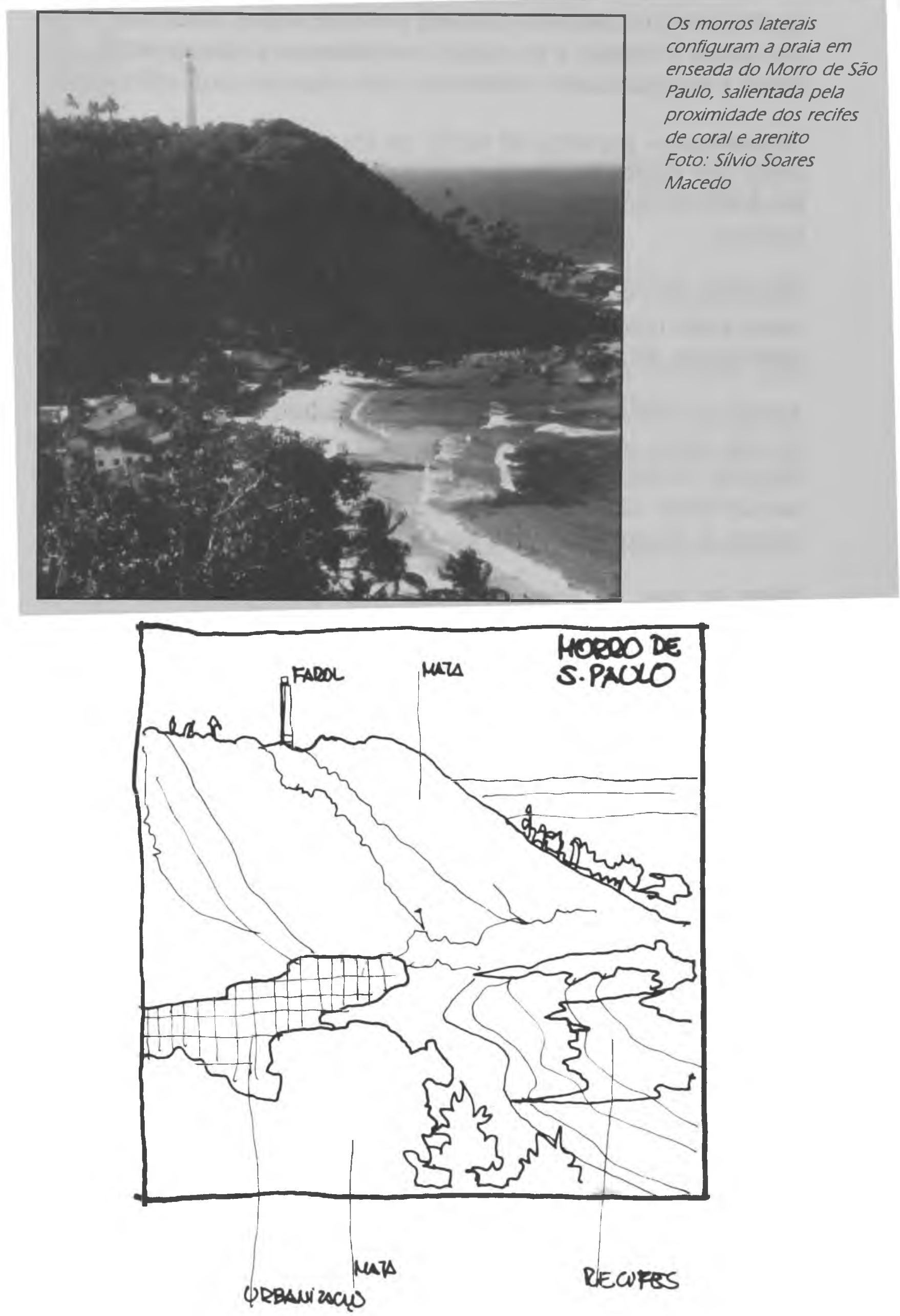

\begin{tabular}{|l|l|l|}
\hline 180 & $\begin{array}{l}\text { Paisagem } \\
\text { Ambiente }\end{array}$ & São Paulo n. 11 p. $131 \quad 202$ dez. 1998 \\
\cline { 3 - 3 } & $\begin{array}{l}\text { Ensaios } \\
11\end{array}$ & \\
\end{tabular}


Praias de enseada - a sua própria estruturação em arco Ihes confere identidade própria, favorecendo a sua caracterização imediata pela população.

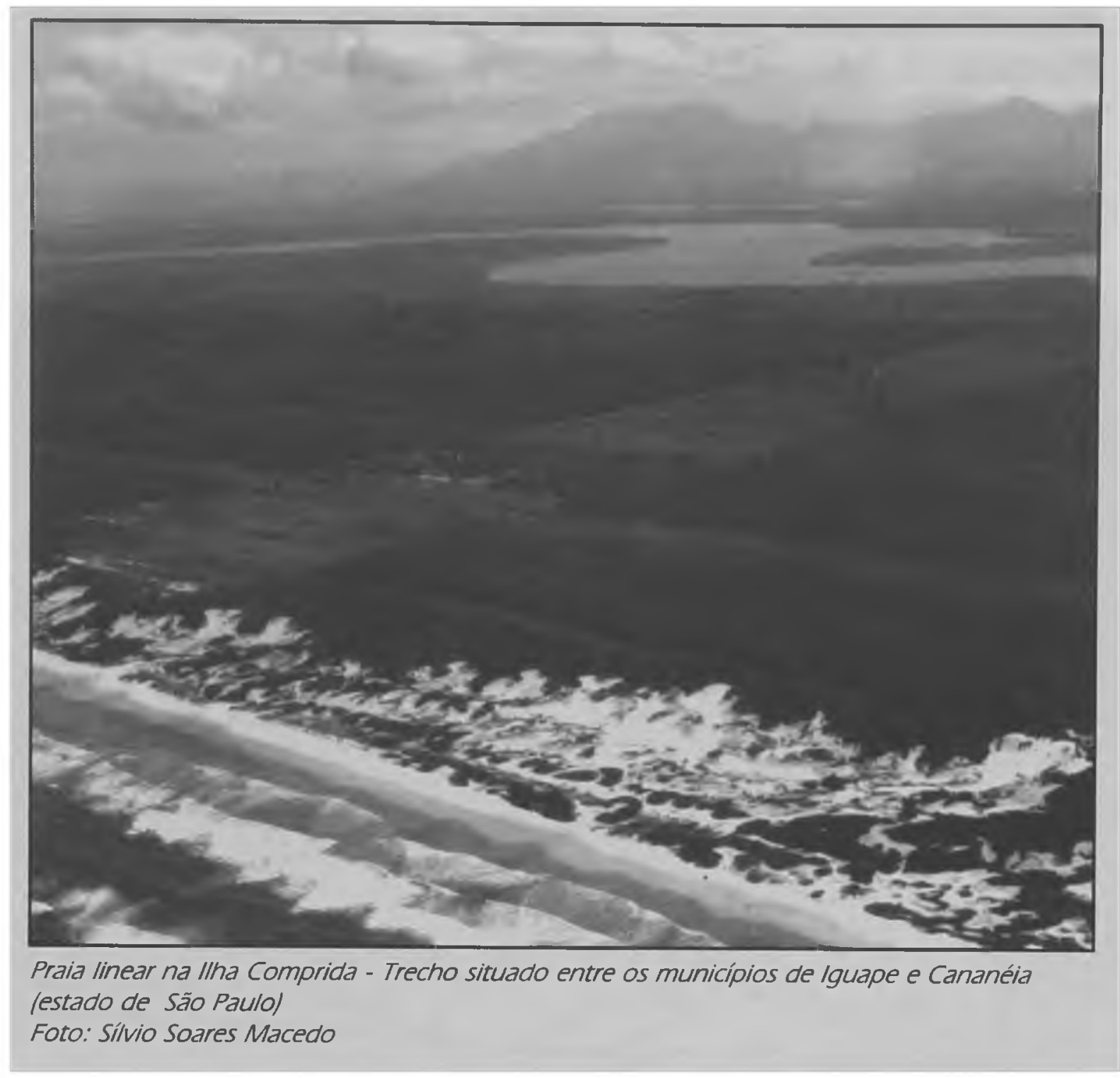

Os demais elementos que possam eventualmente estruturar a paisagem costeira são considerados como valores paisagísticos secundários. Dentro do ideal vigente. A vegetação (matas, manguezais ou coqueirais), os morros, lagoas e rios existentes por toda a costa do país são, do ponto de vista popular, relegados a um segundo plano, constituindo apenas cenários para as atividades sociais e de lazer, que se desenrolam nas praias. Os valores sociais essencialmente urbanos são então definidores da qualidade da praia, que tanto melhor será (em termos turísticos) quanto mais atrativos sociais oferecer: feiras de artesanato, festas populares, prática de esportes como mergulho, surfe, windsurfe, vela, pesca, passeios de "bugre" ultraleve, vida 
noturna, "badalação" condomínios, enfim, tudo que signifique a presença de gente.

Estes padrōes correspondem a estruturas morfológicas urbanas determinadas (vide esquema gráficos anteriores) e estão sempre associados à figura de praia típica brasileira, sendo sua paisagem caracterizada especialmente pela trilogia praia-mar-edificação.

A presença da vegetação urbanizada sob a forma de jardins é uma regra do modelo adotado, enquanto a vegetação nativa - quando não

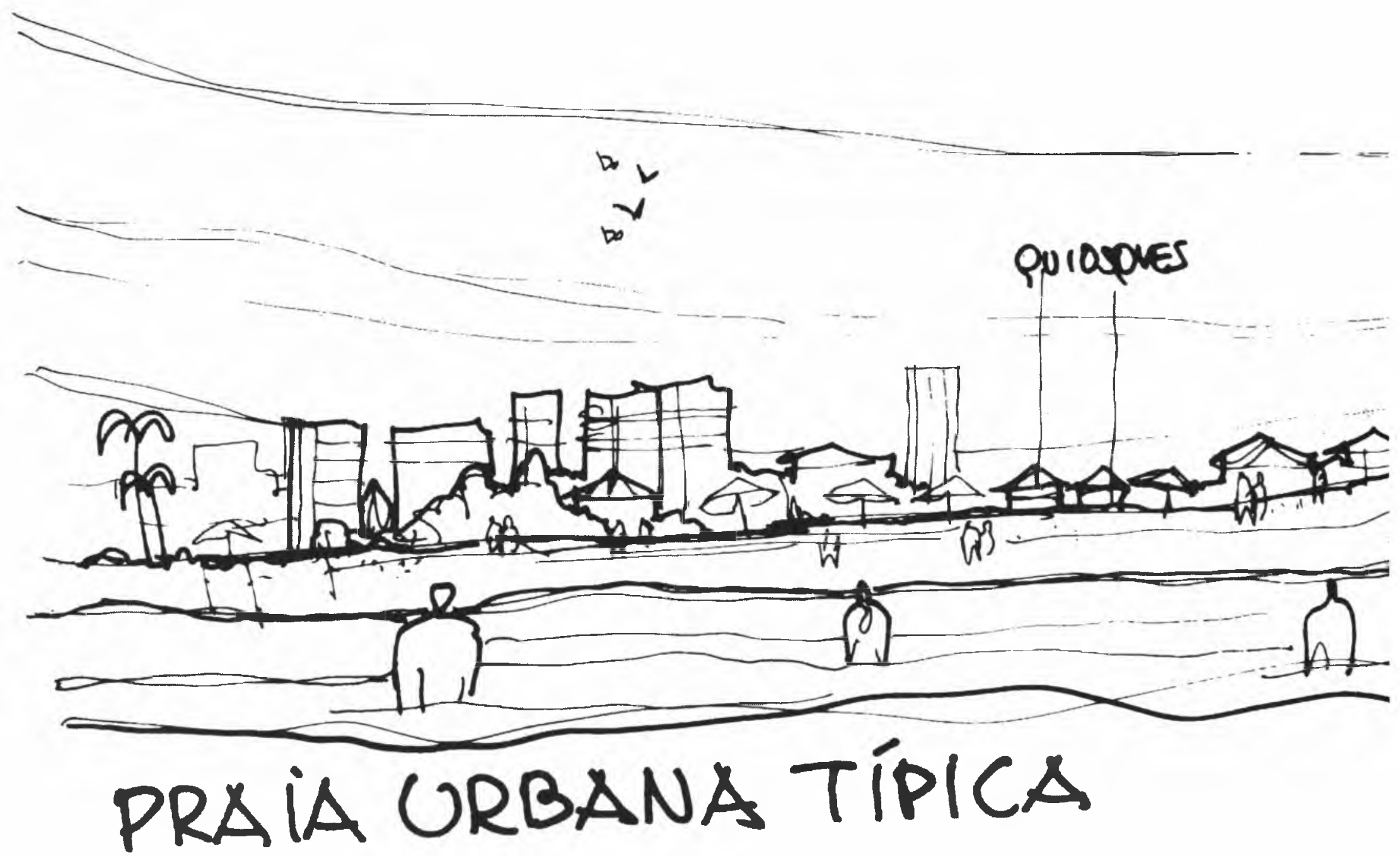


eliminada - é pelo menos tolerada apenas como um fundo distante. Este fato se observa mesmo em situações onde a presença da mata original é uma constante, como é o caso de llhabela, (município - ilha do estado de São Paulo), que possui a maior parte de seu território ocupado por Mata Atlântica. Neste município, em praticamente todas as áreas urbanizadas vizinhas à mata, os espaços livres de edificação foram ajardinados, pouco restando das espécies ali existentes. A mata, um grande cenário, restringe-se à área do parque estadual (que ocupa quase toda a área não urbana).

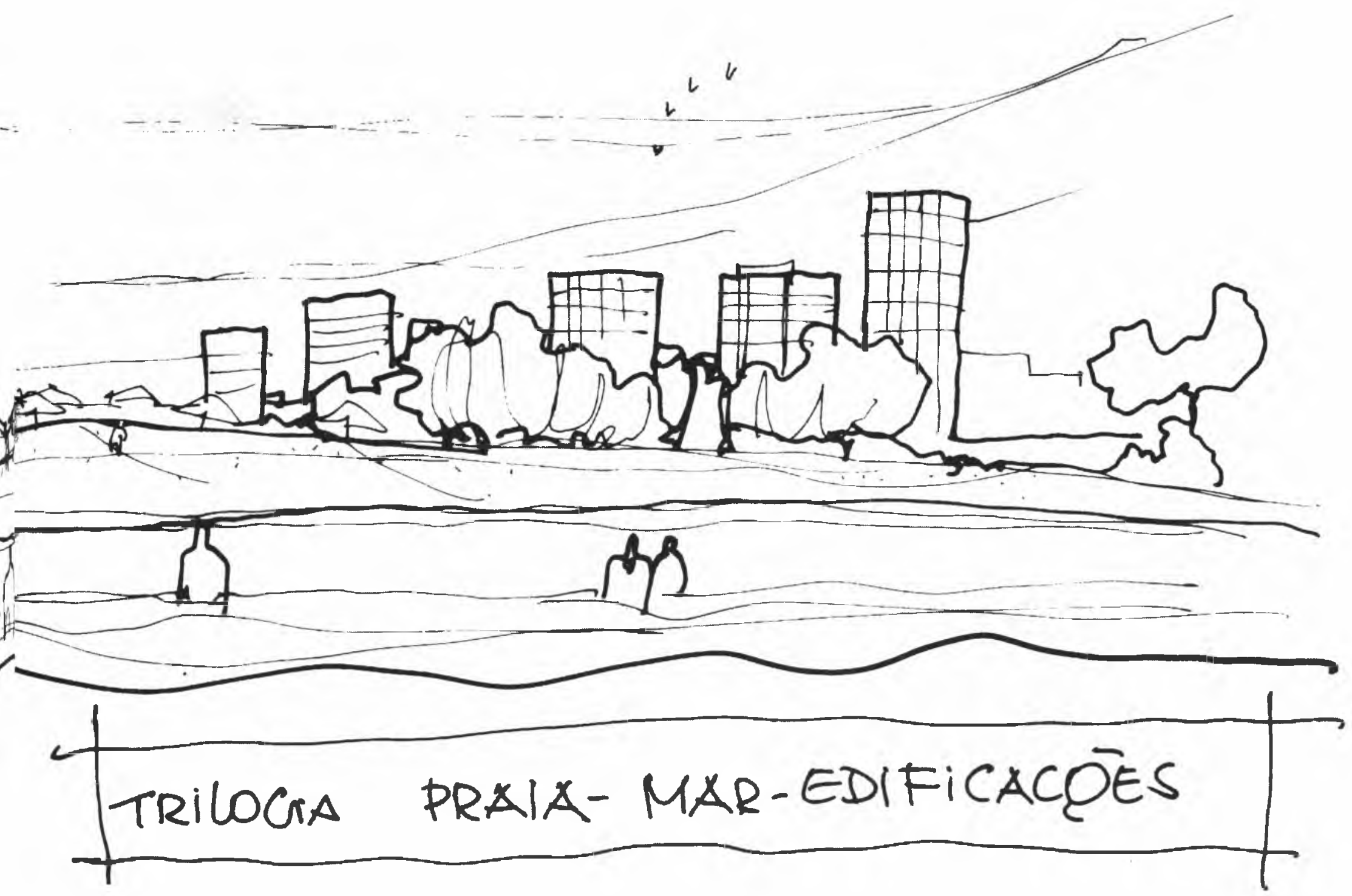




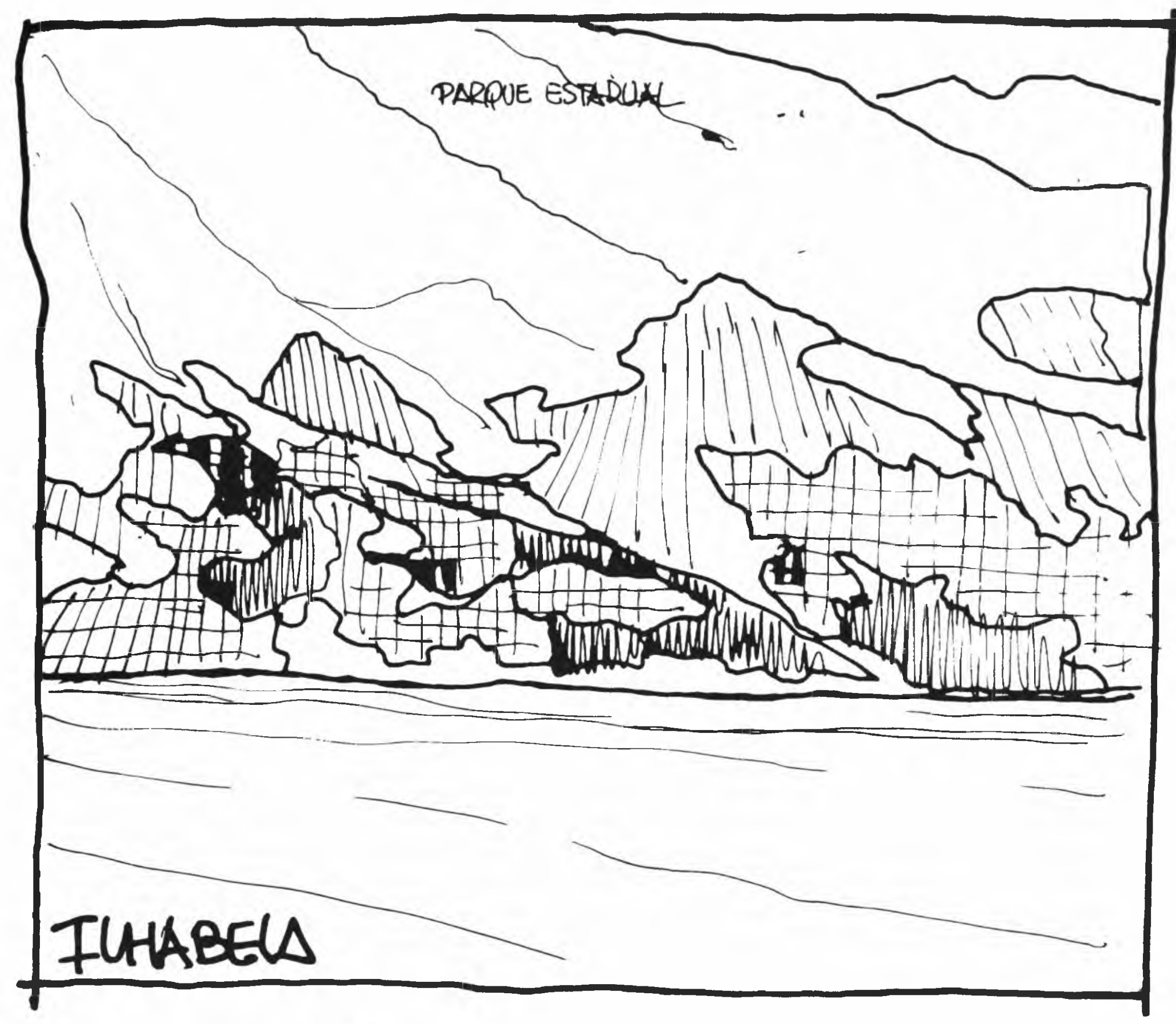

\section{\# MATA ATIÂTICA}

IIII ÁREAS DESTRATADAS

颃 VEGEZSCAO GRBANA

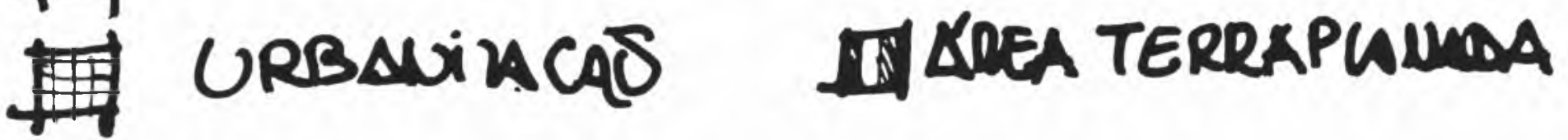


Sílvio

Soares

Macedo

desconhecimento do seu valor paisagístico e ambiental e também da dificuldade de acesso a tais áreas. Tal dificuldade deve-se principalmente à situação de constante alagamento de suas terras pela maré, de seu solo lodoso e do entrelaçamento de sua vegetação. Se por um lado, estas barreiras limitaram o seu uso pleno para o lazer, por outro lado barraram em diversos pontos sua ocupaçāo por assentamentos urbanos, conservando-o de qualquer forma, a própria morfologia do local já desanima qualquer grande empreendimento imobiliário 25

Somente nos anos 80, com o desenvolvimento de uma postura ecológica pelo país, é que os mangues passaram a ter reconhecida sua importância como banco genético e começaram a ser oficialmente preservados 26 . Apesar disto, continuam ainda pouco considerados pela maioria da população como área de grande valor paisagístico ${ }^{27}$ justamente pelas dificuldades de acesso e permanência.

(25) "Várzeas e mangues também constituíram empecilhos para o avanço do tecido urbano, que os evitou até que pudesse conquistá-los através de grandes obras de engenharia, ou melhor, até que tal conquista se fizesse necessária e desejável.

"Os mangues, que um dia protegiam a retaguarda do Rio de Janeiro e que compunham paisagens desoladas da Baixada Santista, foram ocupados depois de bem estudadas drenagens.

In: MARX, Murilo. Cidade brasileira, p. 70.

(26) A nova Constituição Federal, em seu capítulo VI sobre Meio Ambiente, parágrafo 4ํ. declara a zona costeira como patrimônio nacional. A partir deste posicionamento do governo federal de diversos estados declararam os manguezais como área de preservação permanente, como é o caso do estado de São Paulo no artigo 197 capítulo IV da sua nova constituição.

In: Constituição da República Federativa do Brasil, IMESP, p. 40 e Constituição do Estado de São Paulo. p. 31.

(27) Durante nossas pesquisas em periódicos especializados em turismo no litoral, apenas esporadicamente observamos a indicaçāo do manguezal como um fator de atração de um determinado trecho da costa, sendo que para os nossos quatro pontos focais de estudo. somente o litoral sul do estado de São Paulo os mangues foram apontados como elementos significativos. 


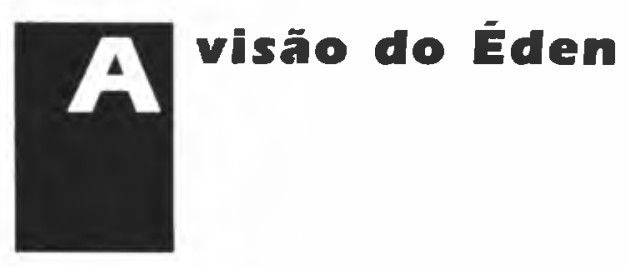

Como contraponto à imagem da praia urbana, definida pela trilogia mar-areia-edificação, massifica-se a partir dos anos 70, uma visão ambientalista como alternativa de valorização das paisagens naturais. Valoriza-se a idéia de estadia em ambientes não ocupados pelo homem, privilegiando o contato com a rusticidade, em locais onde a atuação humana se expressa de um modo discreto. Esta forma de dispender o tempo livre ficou conhecida como "turismo alternativo" exigindo a princípio muito pouca infra-estrutura para sua efetivação, já que pretendia conquistar poucos adeptos 28

A estes locais é então atribuído novos valores devido principalmente a dois atributos básicos: excepcionalidade e qualidade estética. Todos possuem altos e indiscutíveis níveis de qualidade ambiental, quase sempre associados a dificuldades de acesso e estadia. Tornam-se então pontos de atração turística compreendendo largos setores da costa ainda não urbanizados - praias extensas bordejadas de falésias e coqueirais, ilhas remotas, regiōes de mata densa, vilas de pescadores... Estes locais são um forte contraponto ao conjunto urbano constituído nas faixas litorâneas tradicionalmente ocupadas para fins turísticos.

A partir deste período muitas destas áreas rústicas foram pressionadas pelos seus usuários para tornarem-se áreas de preservação ou serem englobadas em parques nacionais e estaduais, de modo a conservar suas características naturais. Este é o caso, por exemplo, de Jericoacoara, no Ceará29 que tentou não repetir a invasão turística de Canoa Quebrada, antigo "paraíso turístico" Esta no final dos anos 70

(28) "Existem viagens e viagens, há aquelas destinadas ao grande público, propostas em todos os lugares e organizadas de acordo com esquemas anônimos. Existem também as viagens para as pessoas diferentes, que gostam de viajar de outra forma.

"O turismo alternativo não é uma noção bem definida. Este apelo é cada vez mais utilizado por toda uma opção de viagens de estudo ou viagens de aventuras, férias a pé ou viagens individuais dos globe trotters."

In: KRIPPENDORF, J. Sociologia do turismo, p. 77.

(29) "Yes, nós temos Jericoacoara. Recentemente, a Washington Post Magazine, revista semanal de um dos mais importantes jornais dos Estados Unidos, publicou reportagem garantindo que não existe outra praia tão bonita nos nossos 8 mil quilômetros de litoral. O ultimo paraíso brasileiro continua sem energia elétrica e é protegido da especulaçāo imobiliária por ser área de preservação ambiental.

Revista Quatro Rodas, ediçāo especial, n. 352, p. 124. 
era intensamente procurada pelas suas virtudes paradisíacas - dunas e dunas desertas junto ao mar e rapidamente foi incorporada ao processo de ocupação urbana tradicional do litoral, sendo que, no final dos anos 80 , já estava ocupada parcialmente por loteamentos convencionais.

Tal como o caso da conservação de Jericoacoara, se tem os casos da llha de Fernando de Noronha, que teve grande parte de seu território transformado em parque marinho; do parque das dunas de Natal e muitos outros....

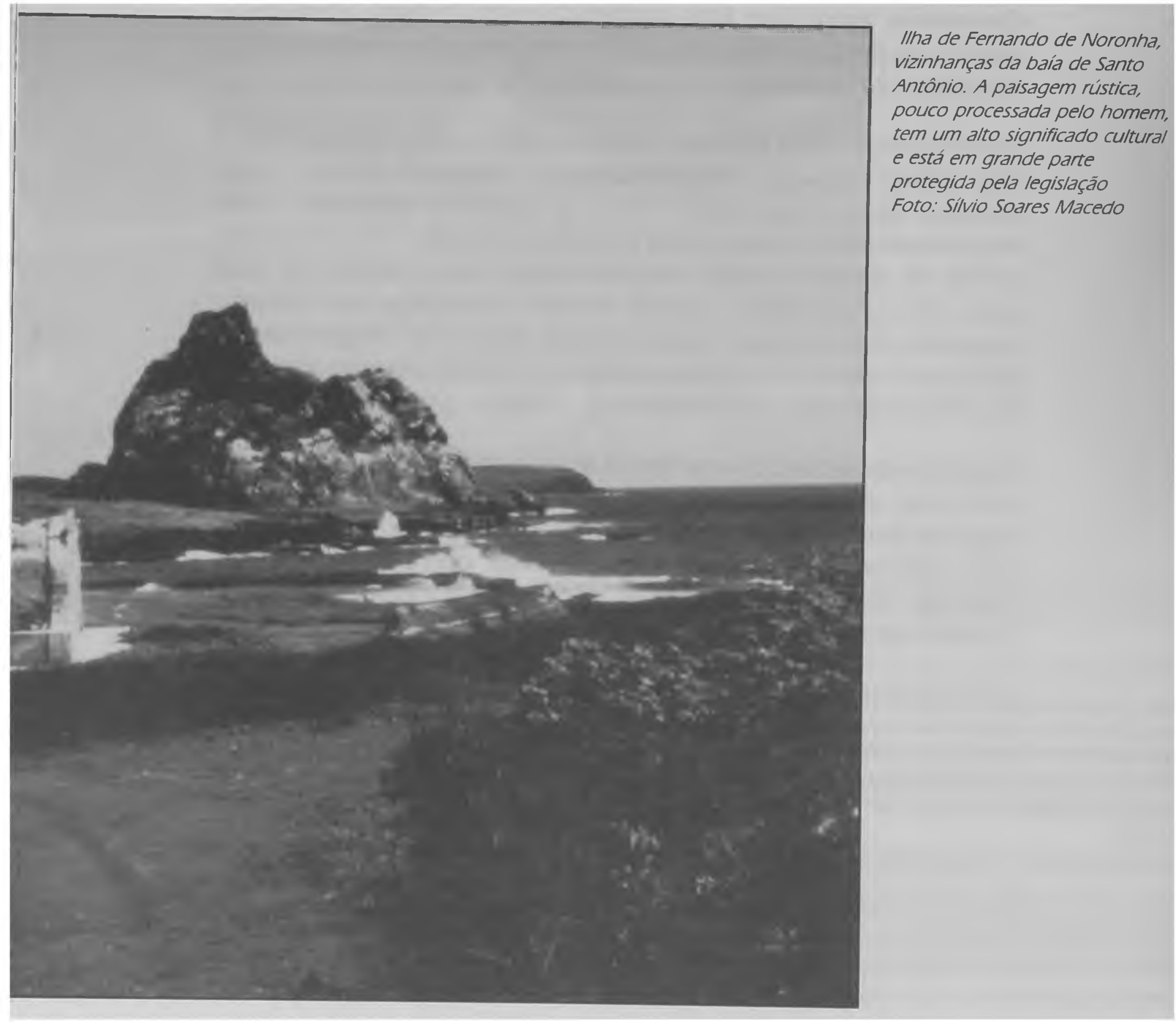




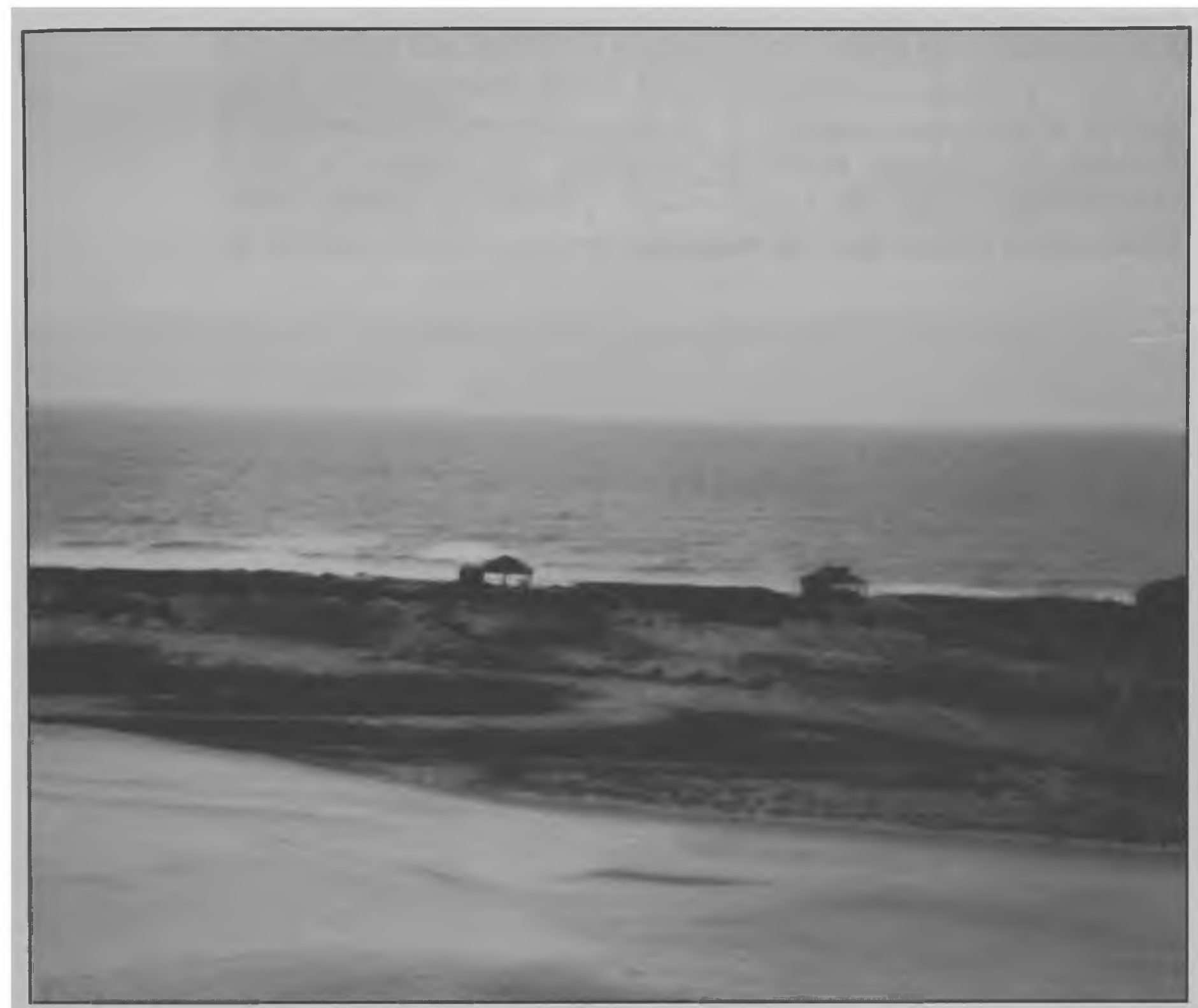

Parque estadual de Itaúnas (Espírito Santo). Região de dunas e extensa várzea, separadas por um riacho. As únicas construçōes permitidas na área são quiosques que pretendem manter o aspecto idílico do local Foto: Josefina Capitani, 1992

A cada novo ponto identificado como "éden" outros tantos antigos paraísos não protegidos por legislação são incorporados aos padrōes tradicionais de ocupação do litoral, à medida que são procurados por contingentes cada vez maiores de visitantes atraídos pela divulgação informal e em revistas especializadas 30

(30) "Sem querer, os turistas alternativos fazem o papel de batedores deste turismo de massa, ao qual justamente tentam escapar. Eles pōem em ação novos mecanismos de mercado, justamente quando um grande número deles sobretudo os jovens, são inimigos declarados da nossa ideologia de consumo. In: KRIPPENDORF J. Sociologia do turismo, p. 80. 
A transformação se efetiva rapidamente e é intensificada pela abertura de novas estradas possibilitando uma rápida integração do antigo paraíso à rede viária nacional e, conseqüentemente, favorecendo a chegada de maiores fluxos de visitantes. As imagens a seguir exemplificam o tipo de transformação possível, a primeira delas mostrando a orla da sede do município de Porto Seguro, que até 20

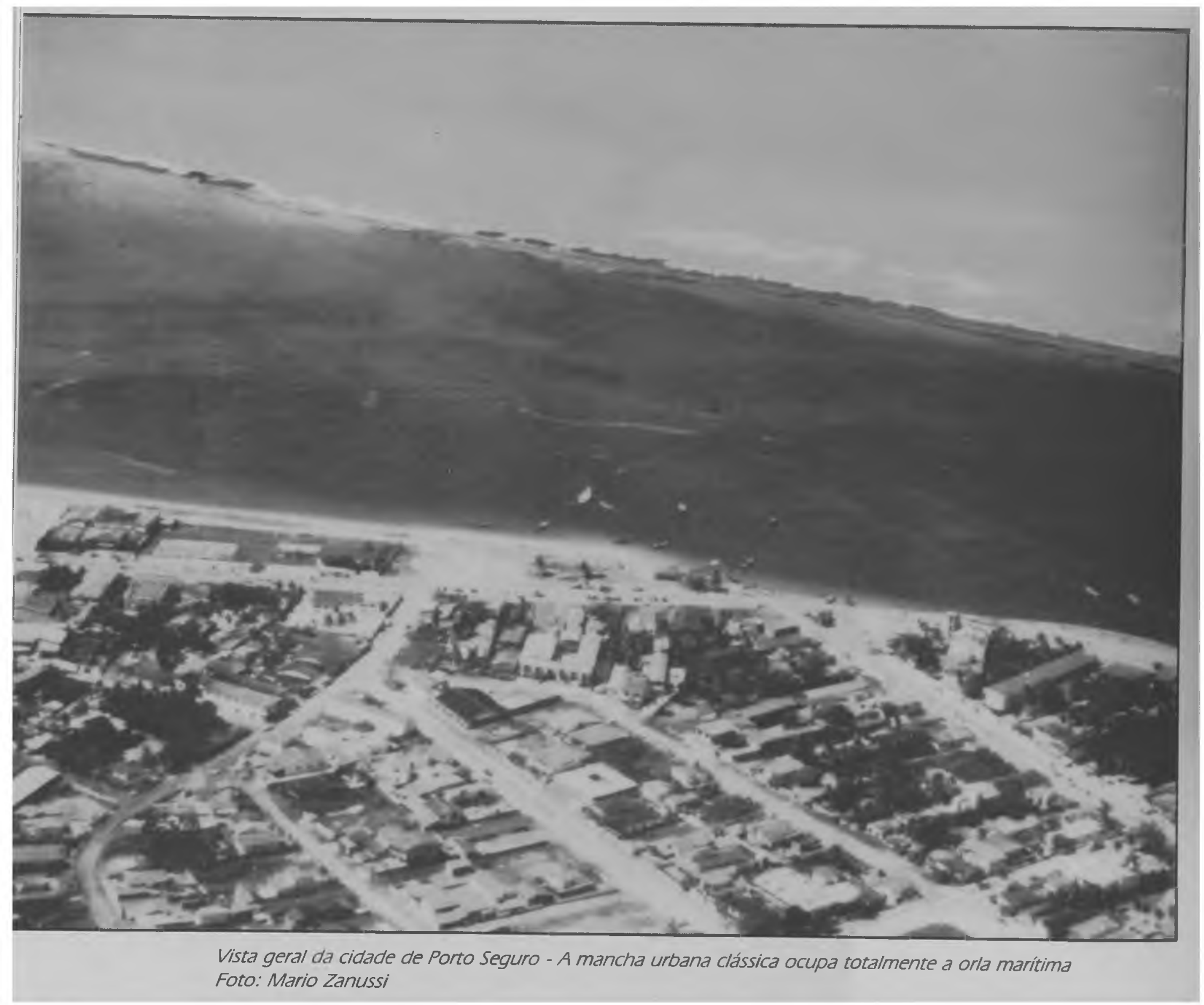


anos atrás era um dos pontos de turismo alternativo e é hoje um centro turístico nacional; segunda apresentando a localidade de Trancoso, no mesmo município, ainda hoje considerada um ambiente "idílico" devido às características rústicas de sua costa e que se encontra hoje em um processo inicial de transformação de sua configuração ${ }^{31}$

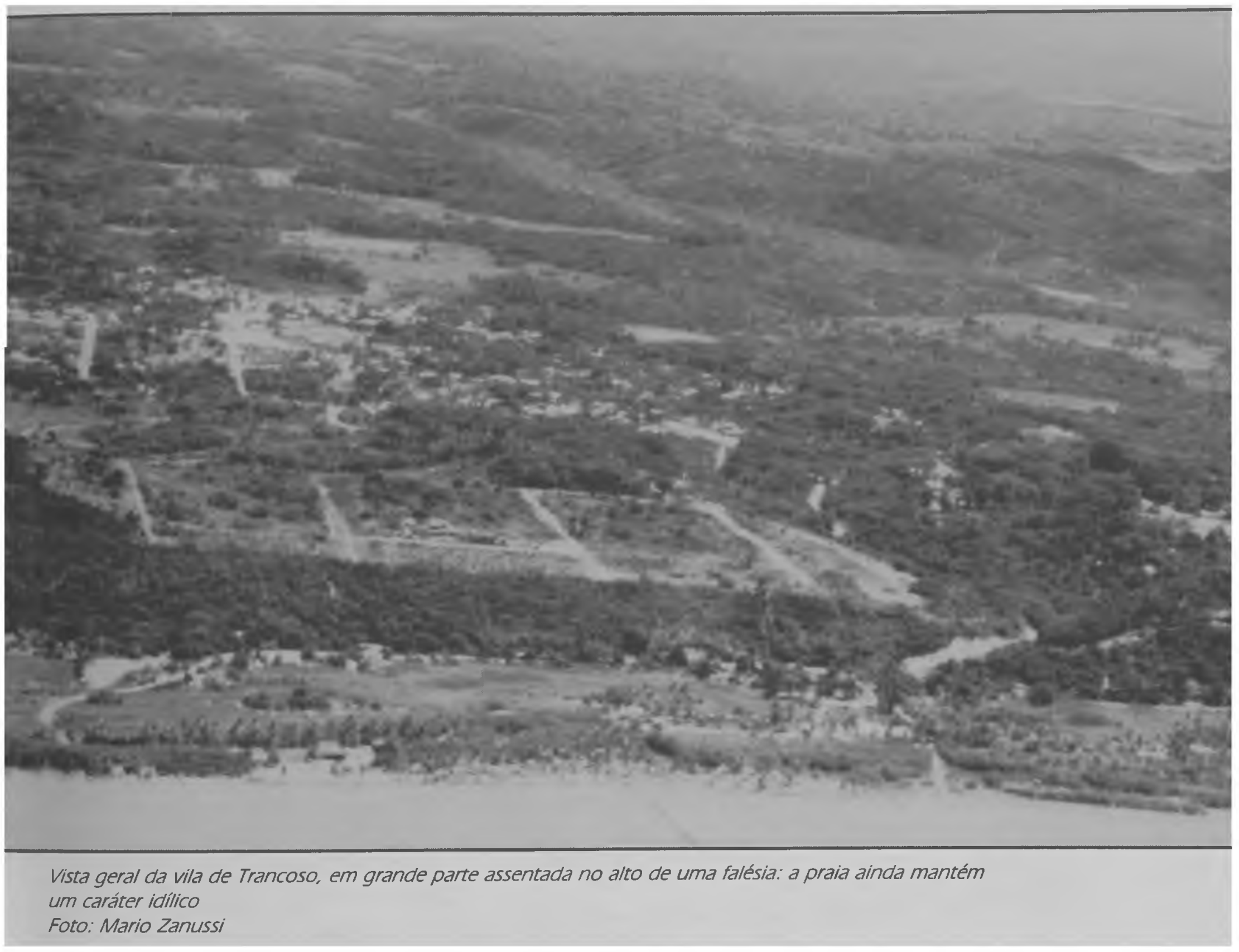

(31) "Trancoso, uma praia larga e batida de ondas, apesar do acesso difícil, foi o mexerico preferido do último verão. Antigo reduto exclusivo dos hippies, este povoado de caiçara abriu-se para multidōes de ecologistas, empresários, artistas, modettes, aventureiros e um número impressionante de turistas estrangeiros. Por enquanto sem grandes prejuízos para a generosa natureza local, mas o acesso à praia fica ano após ano mais difícil, devido às cercas e muros que são levantados.

In: Praias, edição especial da Revista Quatro Rodas, n. 364, p. 54. 
Sílvio

Soares

Macedo

Pode-se então identificar as seguintes etapas de processamento de uma paisagem litorânea típica - da fase "paraíso" até a forma "loteamento tradicional" 32

1 Descoberta do local - Chegada dos primeiros visitantes. Características gerais: difícil acesso, paisagem rústica e isolamento.

2. Consolidação no imaginário turístico do local como "Éden" Características gerais: acesso difícil, paisagens rústicas, surgimento de pousadas, mudança de hábito de parte da população lque, se existente, passa a trabalhar com turismol, venda de casas a turistas.

3. Transformação. Características gerais: perda total da paisagem rústica, o "éden" sendo substituído por uma paisagem litorânea clássica, mesmo que a visão mítica do paraíso continue, sendo um chamariz de vendas do local.

Momento 1 surgimento de loteamentos, melhoria de acessos.

Momento 2: transformação total da paisagem local, formando tecidos urbanos convencionais, abrindo-se vias beira-mar e efetivando-se uma alteração radical dos hábitos da comunidade; o turismo passa a ser uma fonte de renda básica.

(32) Este é um processo que se repete por todos os pontos onde a indústria do turismo se assenta. Procedimentos similares de apropriaçāo dos recursos paisagísticos e construçāo de uma infra-estrutura para o consumo das massas sāo encontradas tanto na África, como Europa e na América. Para maiores detalhamentos destes procedimentos sugere-se a leitura dos trabalhos: $A$ sociologia do turismo de J. KRIPPENDORF e L'Aménagement Touristique de Cazes, LANOUAR e RAYONARD. 

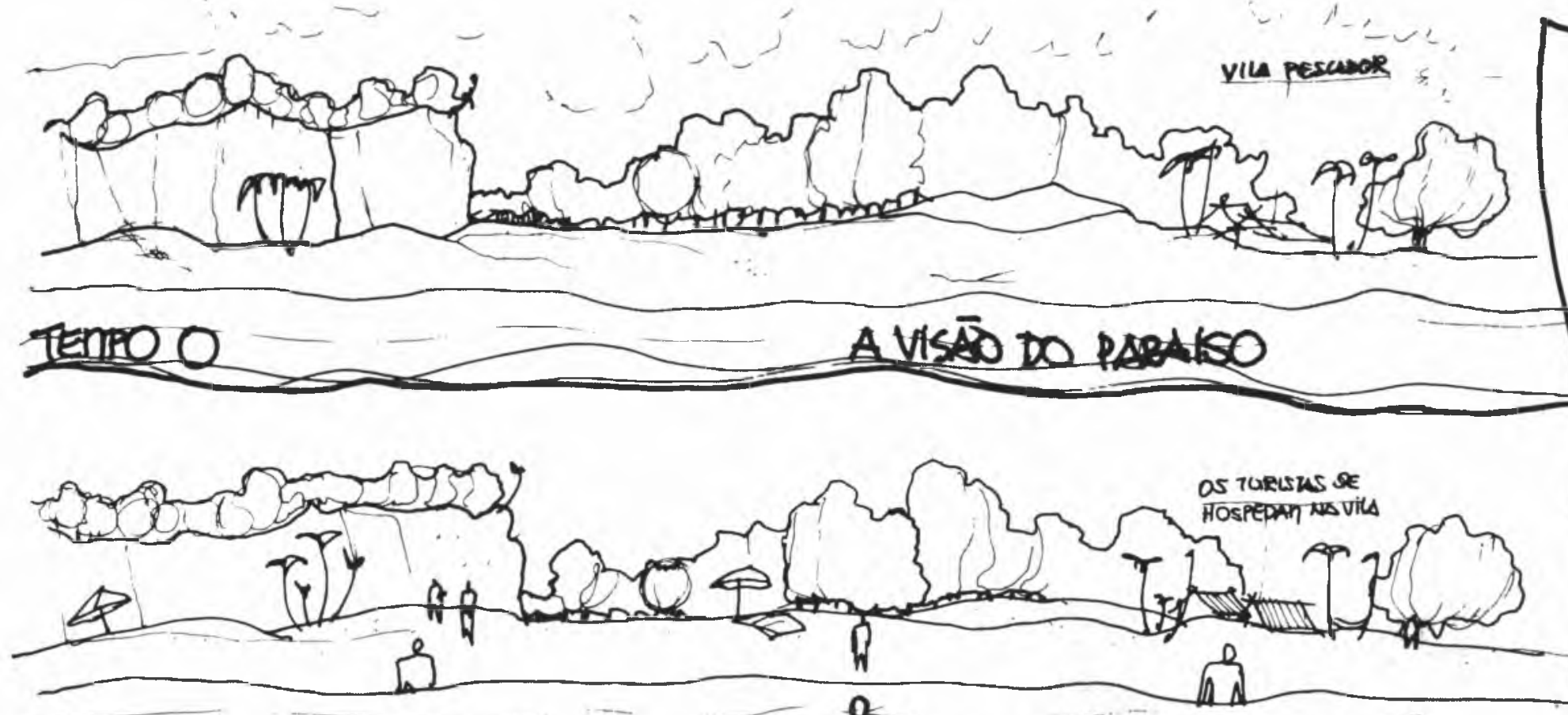

\section{TEMPO 1}

\section{poosina}

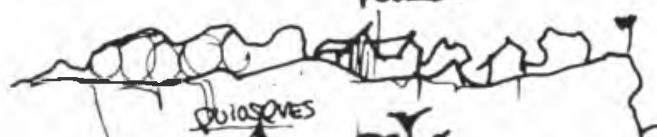

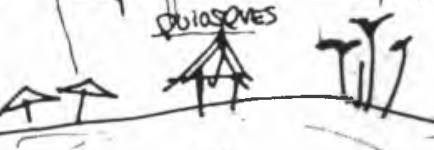

TENPO 2

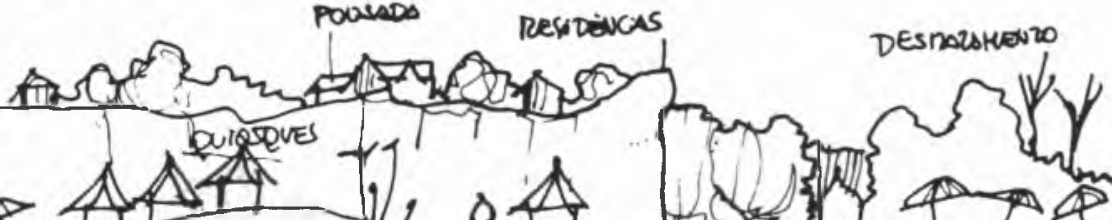

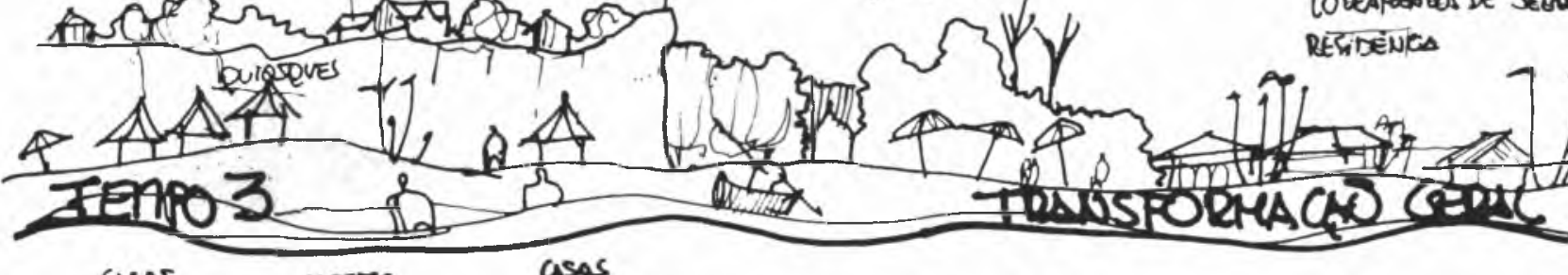

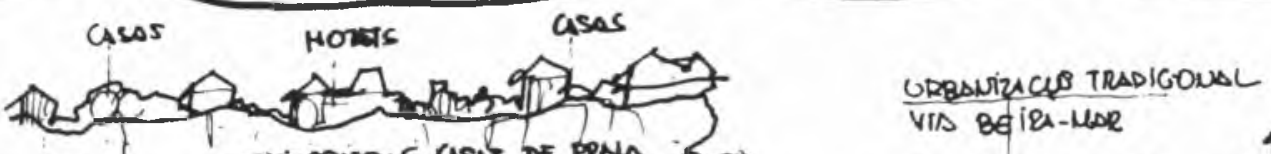

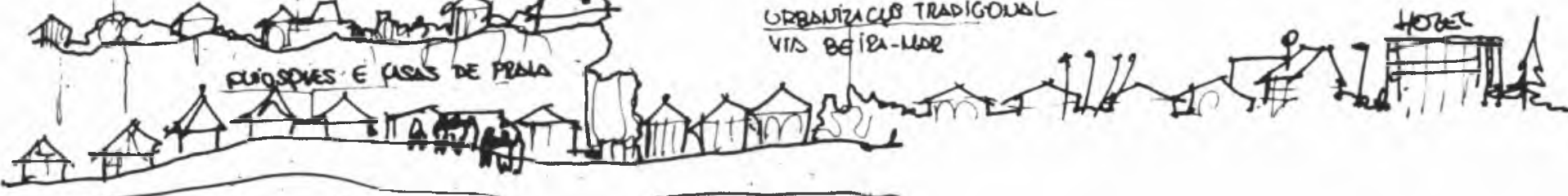

\section{$\triangle$ vilA Cresce}

\section{in \\ A CHESADA AO PARAISO}

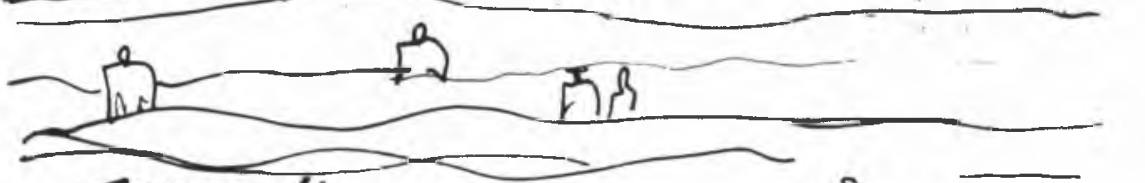

TEMPO 4. 


\section{0}

\section{modelo reticulado e a sua} incompatibilidade com os ecossistemas costeiros

A retícula-padrão, adotada para os loteamentos praianos, é incompatível com qualquer prática que se queira estabelecer para a manutenção de trechos significativos de um ecossistema costeiro.

Manguezais, restingas e dunas são exemplo que não suportam uma ocupação intensiva por estruturas urbanas convencionais. O parcelamento de seus territórios pode significar a sua destruição imediata, pois os ecossistemas costeiros não podem ser reduzidos a partes dissociadas entre si, sem que ocorra uma perda significativa de suas características.

Do mesmo modo que os loteamentos em xadrez, praticamente todas as outras formas de loteamentos litorâneos não são projetadas em função da dinâmica ambiental dos lugares sobre os quais se assentam, o que ocorre são variações de estrutura de sistema viário. Nestas se valorizam caminhos de pedestres e eventualmente se constroem ruas sinuosas que pouco colaboram para a integridade do ecossistema.

Os dois esquemas a seguir mostram o processo típico de fragmentação de alguns dos mais importantes ecossistemas litorâneos.

Caso A - Focaliza um segmento da costa composto por matas de restinga, praias e dunas.

O resultado final da ocupação é previsível: destruição total da restinga e intensiva ocupação da duna, quando seria desejável justamente o oposto às situações habitualmente criadas na urbanização da costa. 0 objetivo seria a ocupação urbana e até o adensamento, mas com a conservação dos recursos ambientais e paisagísticos. 

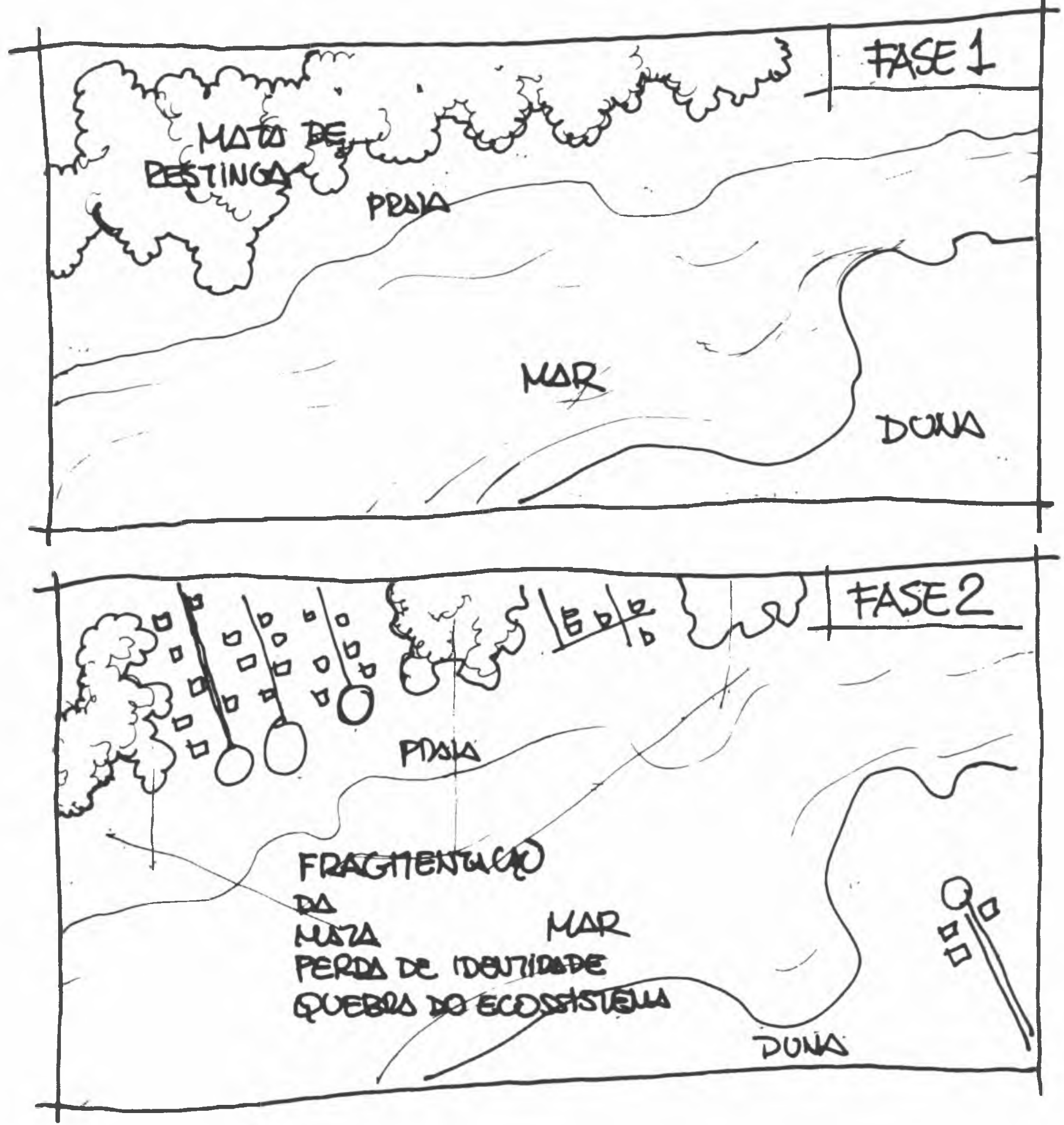
O esquema alternativo apresenta uma das possíveis respostas à questão da conservação, onde no caso se privilegia:

1 A manutenção de manchas contínuas e significativas das matas de restinga.

2. A ocupação intensiva de apenas alguns segmentos da beira-mar.

3. A ocupação pontual das dunas.

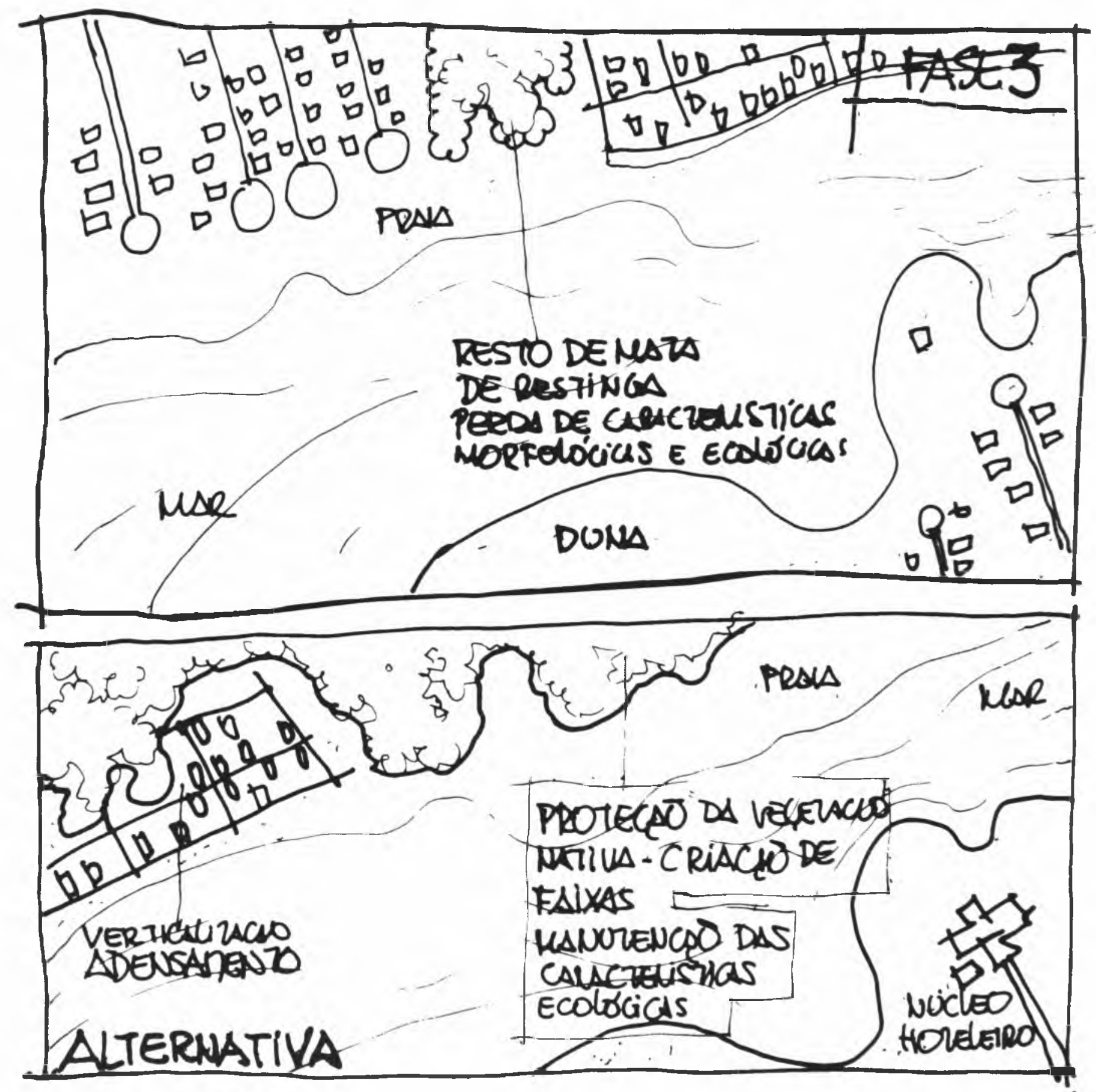


O que se observa é que juntamente com a inexistência de intenções definidas de consenvação, o próprio modelo urbanístico favorece a destruição do ambiente. Não existe qualquer intenção projetual que possibilite a formalização de projetos compatíveis com o meio existente. Nas praias, assim como em todos os pontos turísticos, destroem-se os velhos ambientes e hábitats e se reconstrói a cidade convencional com os seus bem comportados jardins ${ }^{33}$

Caso B - O esquema mostra o processo clássico de ocupação de um loteamento onde, a princípio, foi mantida a mata nativa nos lotes, mas estes são pouco a pouco transformados em lotes urbanos convencionais.

A cada assentamento urbano em áreas costeiras existe ao menos uma forma alternativa que pode viabilizar, a partir de objetivos conservacionistas, um projeto de urbanização para o local, que conserve os ecossistemas locais e abrigue um número igual ou superior ao de um loteamento convencional ${ }^{34}$.

(33) “É importante lembrar que o paisagismo urbano é configurado para usos humanos específicos e está muito longe do que seria considerado estado natural usualmente. Plantam-se espécies exóticas de vegetaçāo que sāo escolhidas mais para efeito visual do que para beneficiar a vida selvagem ou por razão ecológica.

In: LYLE, John. Design with human ecosystems. p. 218.

(34) Esquemas gráficos baseados em estudos de projeto.

In: PENTEADO, Fernanda B. Trabalho de graduação Interdisciplinar Condomínios de Praia. 1991 s.p.

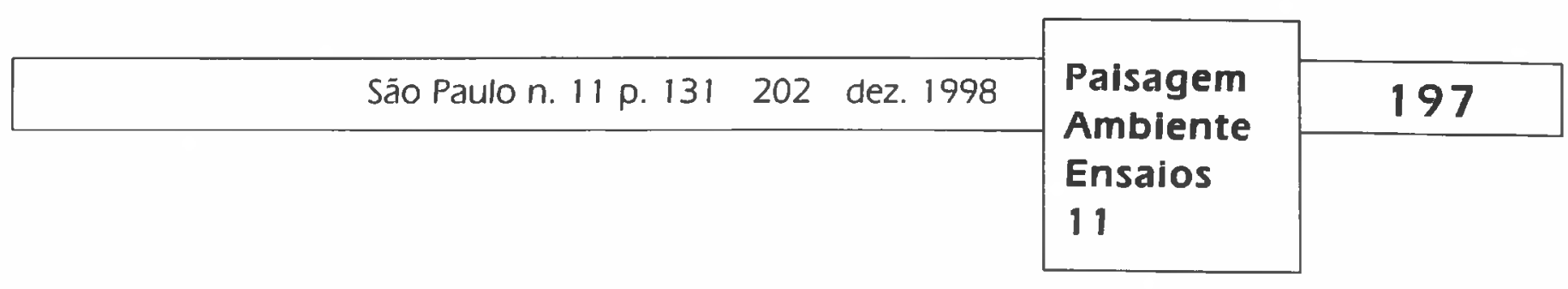




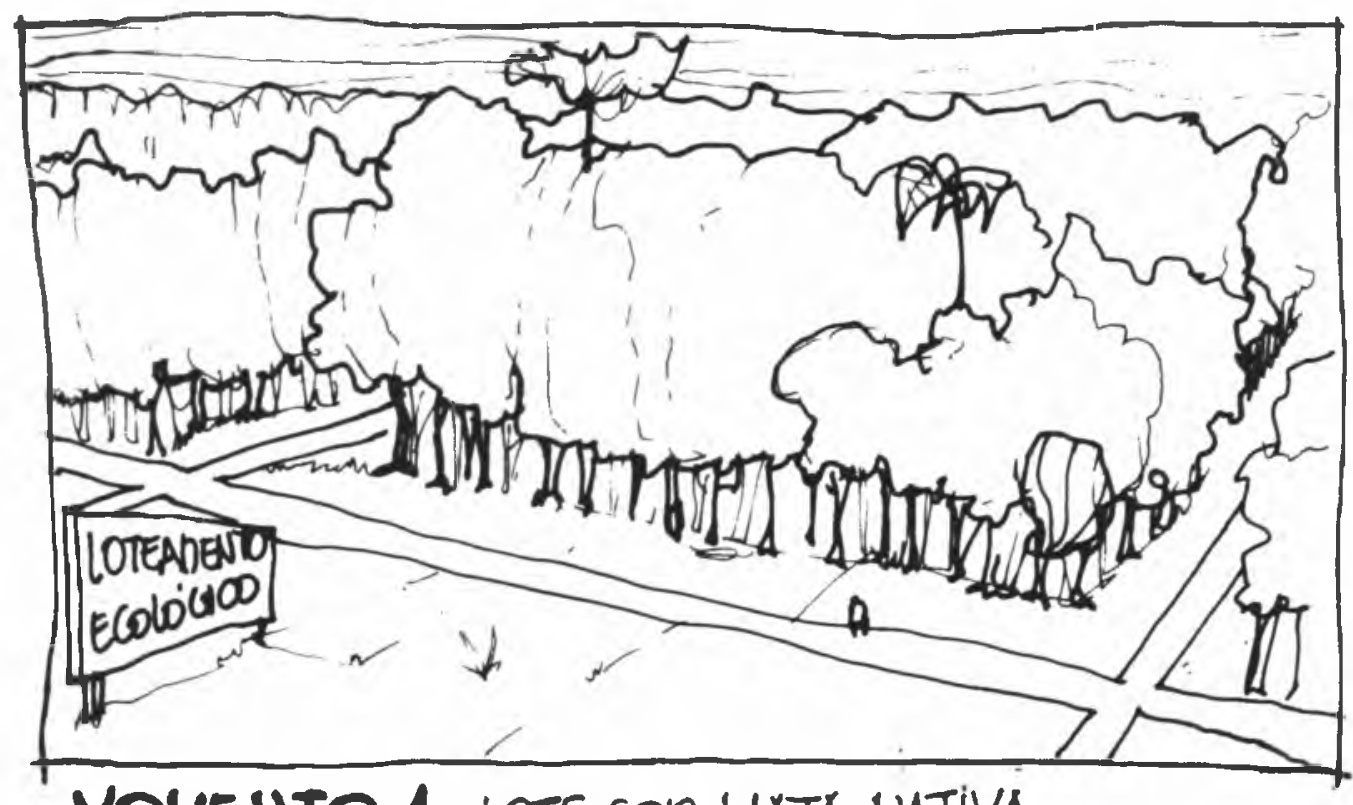

MOMENTO 1-LOTE CON MATA NATIVA
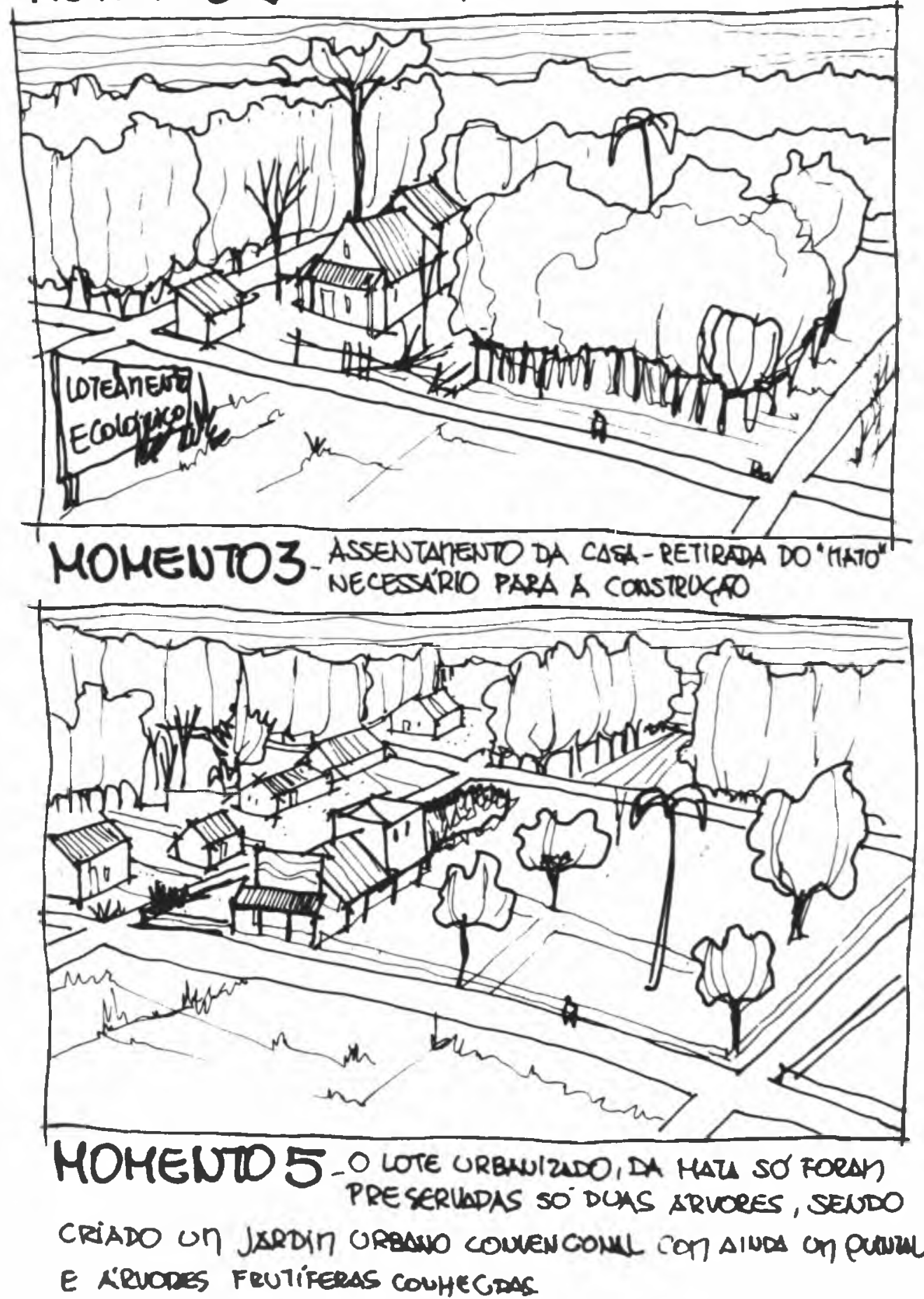


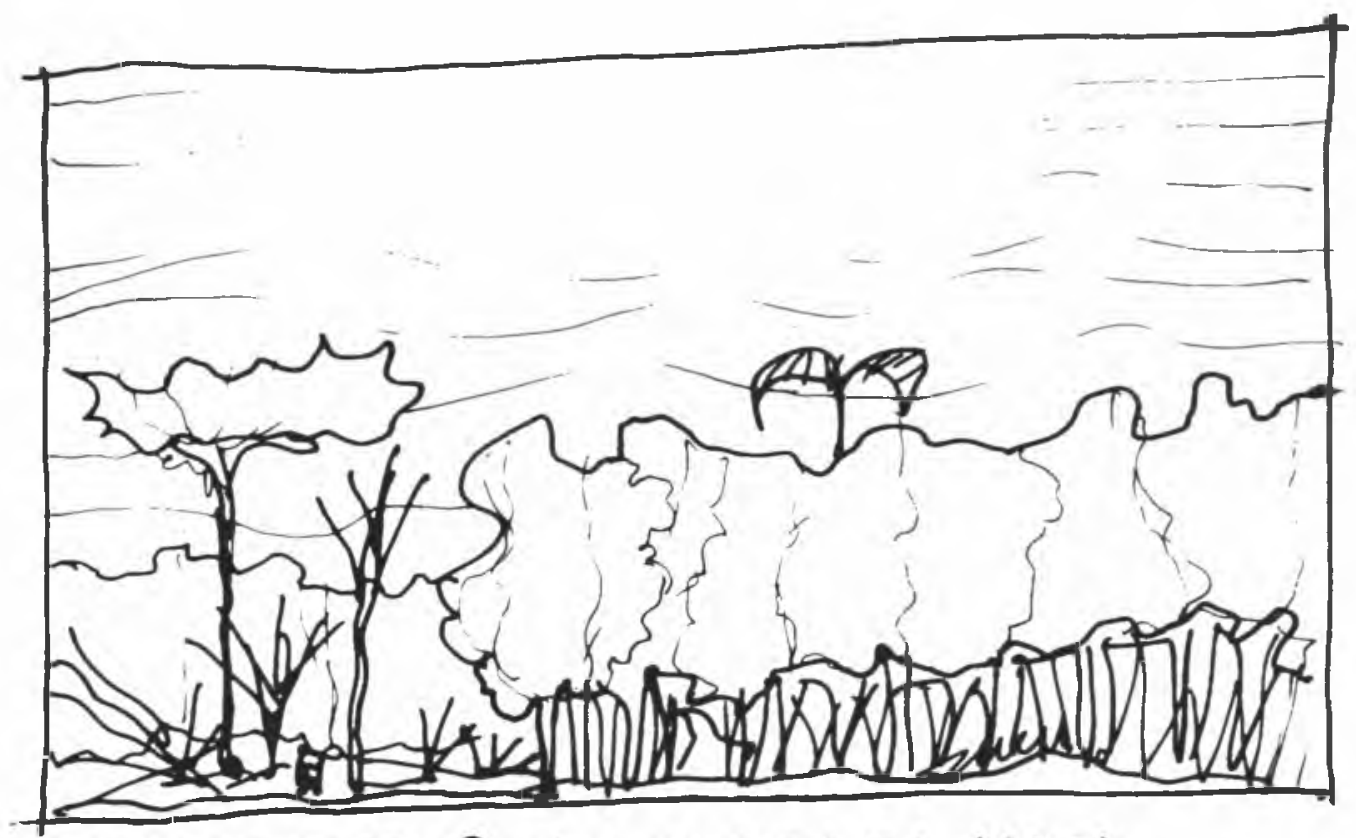

MOMENTO 2-DERRUBada DA MATA

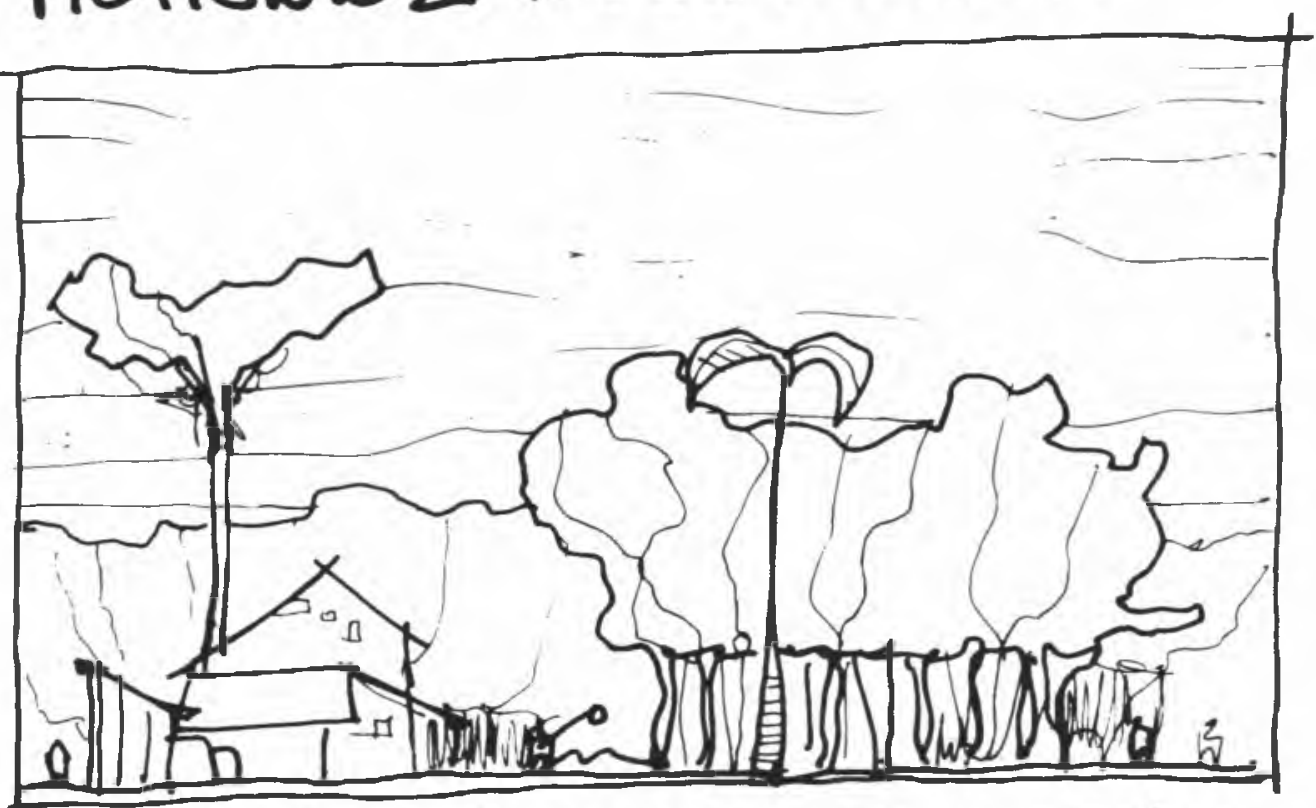

MOMENTO 4-CONSERUACAD DE ESPÉCIES

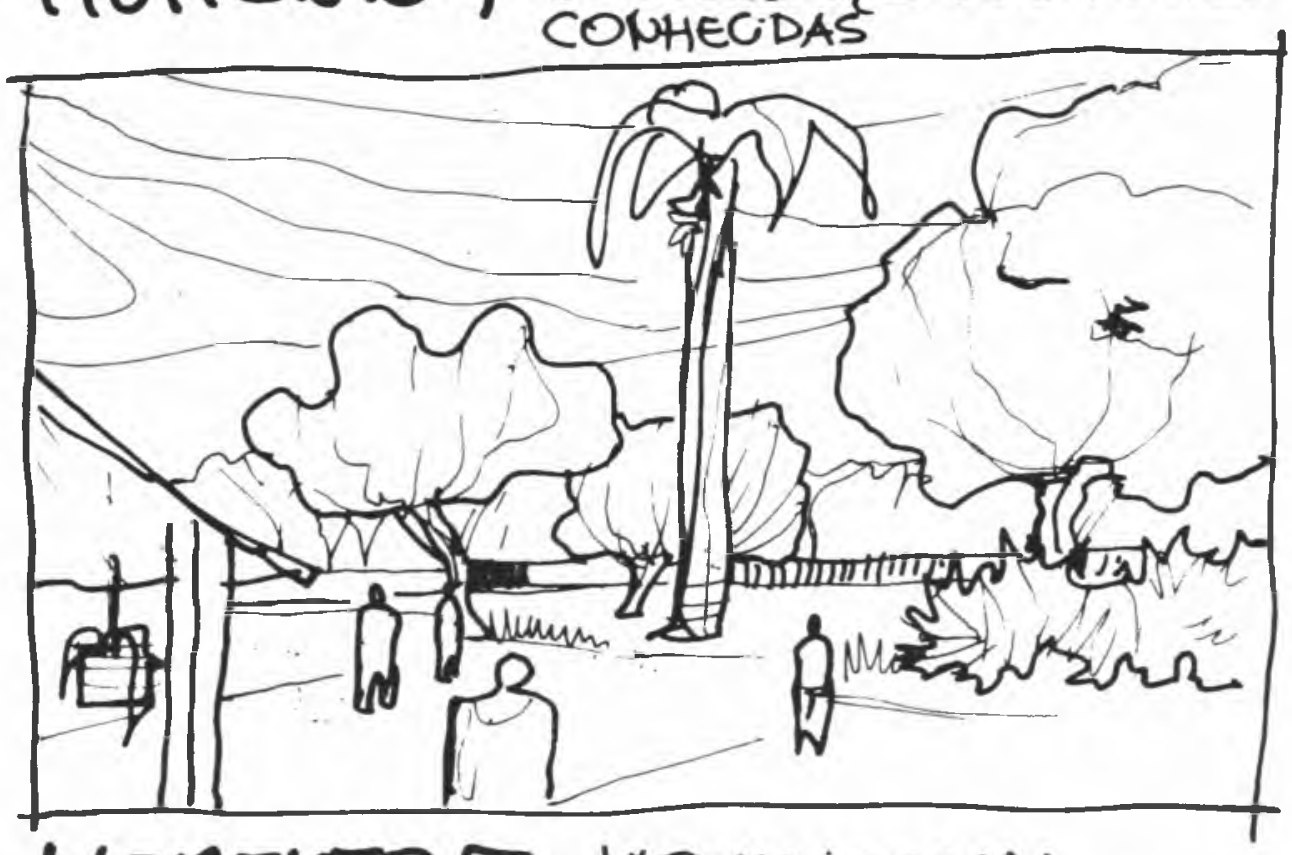

MOMENTO5 - JARDII FORMAL 

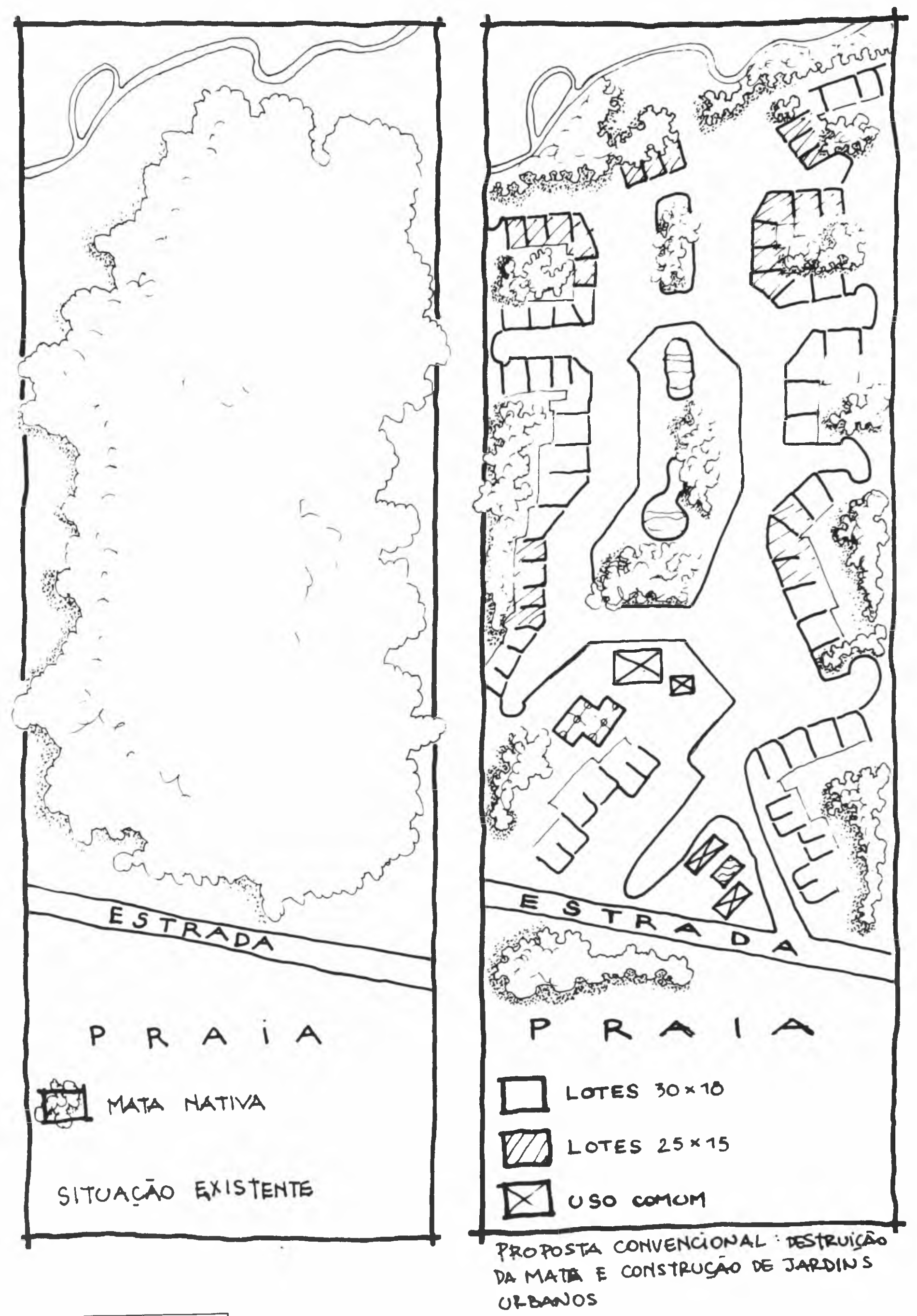


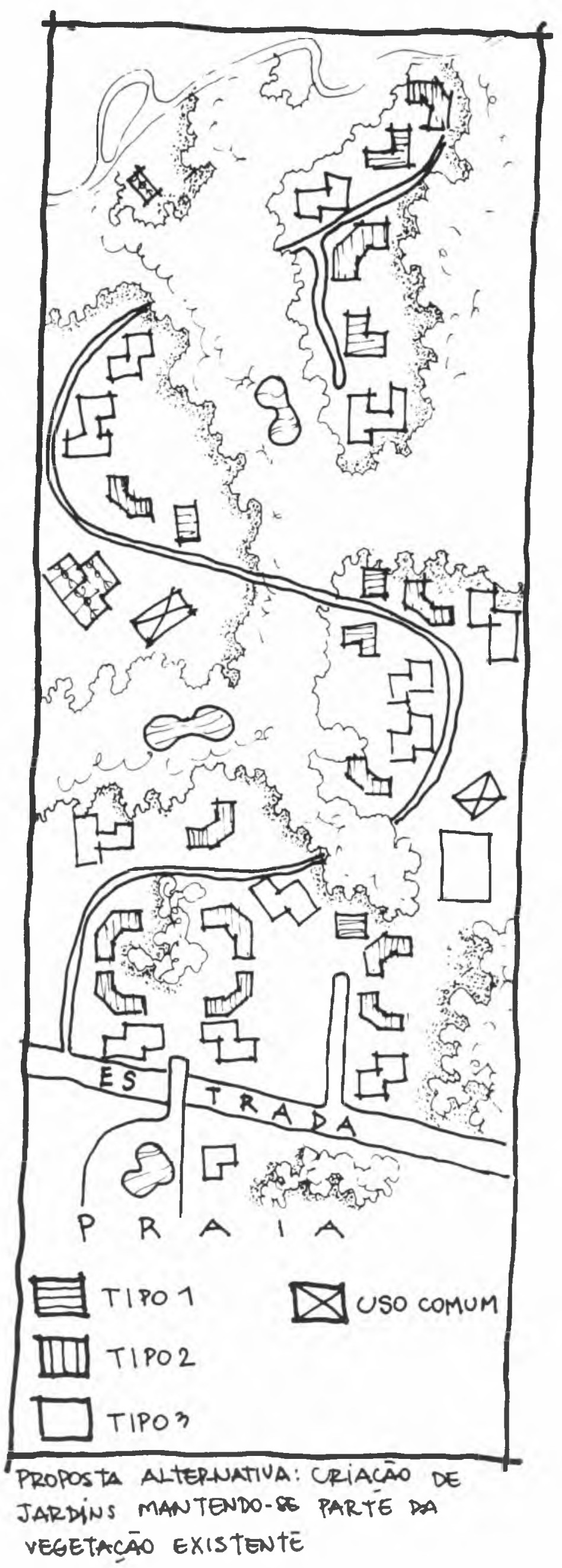




\section{BIBLIOG RAFIA}

BIRKHOLZ et al. Questōes de organização do espaço regional. São Paulo: Nobel/Edusp, 1983. BRASIL. Constituição da República Federativa do Brasil, de 05 de outubro de 1988, Brasília, 1988.

CAZES, G., LANQUAR, R., RAYONARD, Y. L'aménagement touristique. França: Presses Universitaires de France, 1990, 128p.

CEPA - Comissão de Estudos Ambientais da Universidade de São Paulo. Relatório Técnico Ponta da Prainha. São Paulo: USP, 1990.

CHOAY, Françoise. O urbanismo. São Paulo: Perspectiva, 1979.

CORBIN, Alain. O território do vazio - A praia e o imaginário. Ocidental. São Paulo: Cia. Letras 1989.

KEIPPENDOFF, J. Sociologia do turismo. para uma nova compreensão do lazer e da viagem. Rio de Janeiro: Civilização Brasileira, 1989.

LYLE, John Tillman. Design for human ecosystems: landscape, land use, and natural resources. Nova York: Van Nostrand Reinhold, 1985, $269 \mathrm{p}$.

MACEDO, Silvio Soares. Paisagem, urbanizaçāo e litoral - Do éden à cidade. São Paulo: FAUUSP, 1998.

Higienópolis e arredores: processo de mutação da paisagem urbana. São Paulo: Edusp/Pini, 1987, 259 p. ilustrado.

MALTA, Maurício; TURCKIENCZ, B. Cadernos brasileiros de arquitetura. In: II SEDUR, São Paulo. Anais. São Paulo: Pini, 1985.

MARX, Murillo. Cidade brasileira. Sāo Paulo: Melhoramentos/Edusp, 1980, 151 p.

MELLO FILHO, Luís Emygidio de. In: MONTEIRO. Salvador, HAZ, Leonel. (org) Floresta Atlântica. Rio de janeiro: Alabramento, 1991.

REVISTA QUATRO RODAS. Praias, anos 1998 a 1992. Edição especial.

SICA, Paolo. Historia del urbanismo - el siglo XIX. Madri: Instituto de Estúdios de Administracion Local, v. 2, 1981.

TABET, Sérgio; POMAR, Berganini, Sonia. O Rio de Janeiro em antigos cartóes postais. Rio de Janeiro: Edição do autor, 1985.

VILLAÇA, Flávio. A estrutura territorial da metrópole sul brasileira. São Paulo, 1978. Tese (Doutorado) - Faculdade de Filosofia, Letras e Ciências Humanas, Universidade de São Paulo.

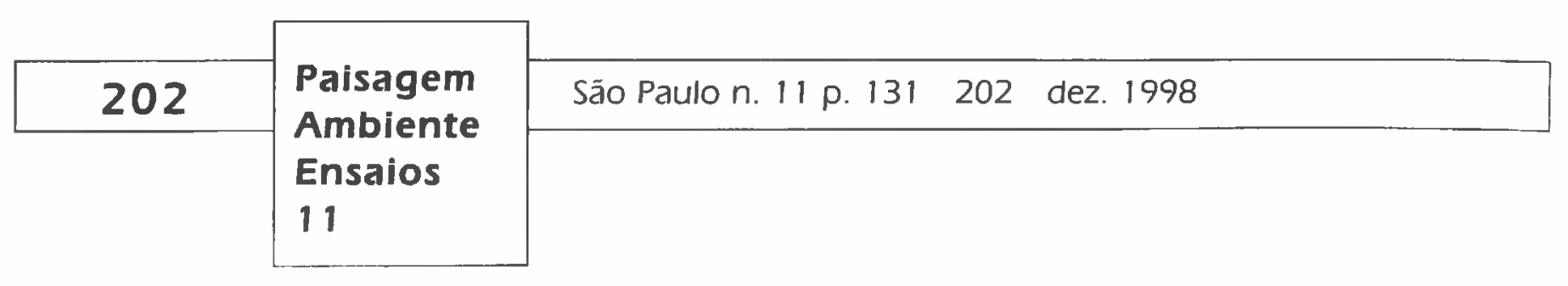

